\title{
Celebrating diversity?
}

Citation for published version (APA):

Kurth, L. R. M. (2017). Celebrating diversity? an empirical study of tensions between the discourses of assimilation and multiculturalism. [Doctoral Thesis, Maastricht University]. Datawyse / Universitaire Pers Maastricht. https://doi.org/10.26481/dis.20171124lk

Document status and date:

Published: 01/01/2017

DOI:

10.26481/dis.20171124lk

Document Version:

Publisher's PDF, also known as Version of record

\section{Please check the document version of this publication:}

- A submitted manuscript is the version of the article upon submission and before peer-review. There can be important differences between the submitted version and the official published version of record.

People interested in the research are advised to contact the author for the final version of the publication, or visit the DOI to the publisher's website.

- The final author version and the galley proof are versions of the publication after peer review.

- The final published version features the final layout of the paper including the volume, issue and page numbers.

Link to publication

\footnotetext{
General rights rights.

- You may freely distribute the URL identifying the publication in the public portal. please follow below link for the End User Agreement:

www.umlib.nl/taverne-license

Take down policy

If you believe that this document breaches copyright please contact us at:

repository@maastrichtuniversity.nl

providing details and we will investigate your claim.
}

Copyright and moral rights for the publications made accessible in the public portal are retained by the authors and/or other copyright owners and it is a condition of accessing publications that users recognise and abide by the legal requirements associated with these

- Users may download and print one copy of any publication from the public portal for the purpose of private study or research.

- You may not further distribute the material or use it for any profit-making activity or commercial gain

If the publication is distributed under the terms of Article $25 \mathrm{fa}$ of the Dutch Copyright Act, indicated by the "Taverne" license above, 


\title{
Celebrating Diversity?
}

\author{
An empirical study of tensions between \\ discourses of assimilation and multiculturalism
}

Laura Ruth Maria Kurth 
(C) copyright Laura Ruth Maria Kurth, Maastricht 2017

Printing: Datawyse | Universitaire Pers Maastricht

ISBN 9789461597687

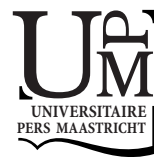




\title{
Celebrating Diversity?
}

\section{An empirical study of tensions between discourses of assimilation and multiculturalism}

\author{
DISSERTATION \\ to obtain the degree of Doctor at Maastricht University, \\ on the authority of the Rector Magnificus, Prof. Dr. Rianne M. Letschert \\ in accordance with the decision of the Board of Deans, \\ to be defended in public \\ on Friday, 24 November 2017, at 14:00 hours
}

by

Laura Ruth Maria Kurth

born on 27-05-1987 in Cologne, Germany 


\section{SUPERVISORS}

Prof. Dr. P. Glasbergen

Prof. Dr. M. Davidson

\section{ASSESSMENT COMMITTEE}

Prof. Dr. P. Martens (chairman)

Prof. Dr. J.J. Boersema (Leiden University, Netherlands)

Dr. T. Havinga (Radboud University Nijmegen, Netherlands)

Dr. C. Scholl

Prof. Dr. B.F. van Waarden (Utrecht University, Netherlands) 


\section{TABLE OF CONTENTS}

CHAPTER 1 INTRODUCTION

Cultural diversity 2

Discourses and policy approaches to cultural diversity 2

Tensions between multiculturalism and assimilation 6

$\begin{array}{ll}\text { Actors in the integration discourses } & 6\end{array}$

Research objective 8

Methods $\quad 8$

$\begin{array}{ll}\text { Case studies } & 10\end{array}$

$\begin{array}{ll}\text { Reference } & 12\end{array}$

CHAPTER 2 DEALING WITH TENSIONS OF MULTICULTURALISM:

THE POLITICS OF RITUAL SLAUGHTER IN THE NETHERLANDS 15

$\begin{array}{ll}\text { Abstract } & 16\end{array}$

$\begin{array}{ll}\text { Introduction } & 17\end{array}$

$\begin{array}{ll}\text { Methodology } & 18\end{array}$

Frame analysis of the Dutch political debate about ritual slaughter 20

Conclusion: Dealing with tensions of multiculturalism 29

References $\quad 32$

CHAPTER 3 SERVING A HETEROGENEOUS MUSLIM IDENTITY? PRIVATE GOVERNANCE ARRANGEMENTS OF HALAL FOOD IN THE NETHERLANDS 35

Abstract $\quad 36$

$\begin{array}{ll}\text { Introduction } & 37\end{array}$

$\begin{array}{ll}\text { Methods } & 39\end{array}$

Diversity within the Dutch Muslim community and its halal consumption $\quad 40$

Multi-level halal governance 43

Dutch halal governance $\quad 45$

Theoretical framework and analysis of the Dutch halal certification bodies $\quad 48$

Conclusion $\quad 54$

References $\quad 56$

CHAPTER 4 THE INFLUENCE OF POPULISM ON TOLERANCE:

A THEMATIC CONTENT ANALYSIS OF THE DUTCH ISLAM DEBATE 61

$\begin{array}{ll}\text { Abstract } & 62\end{array}$

Introduction 63

Culturalization of politics and de-culturalization of liberalism 64

Analytical framework: The concept of tolerance dismantled 65 
$\begin{array}{ll}\text { Methods } & 67\end{array}$

$\begin{array}{ll}\text { Emergence of populism in the Netherlands } & 69\end{array}$

$\begin{array}{ll}\text { Shifting meaning of Dutch tolerance } & 70\end{array}$

$\begin{array}{ll}\text { Discussion } & 76\end{array}$

Appendix: Newspaper articles directly quoted 78

$\begin{array}{ll}\text { References } & 79\end{array}$

CHAPTER 5 MIND THE GAP: ETHNIC/ISLAMIC ORGANIZATIONS

BETWEEN MULTICULTURALISM AND ASSIMILATION 81

$\begin{array}{ll}\text { Abstract } & 82\end{array}$

Introduction $\quad 83$

$\begin{array}{ll}\text { Dutch history of integration } & 84\end{array}$

$\begin{array}{ll}\text { Methods } & 86\end{array}$

Contextualizing E/IOs in the Netherlands 88

$\begin{array}{ll}\text { Analysis } & 90\end{array}$

Discussion \& conclusion $\quad 96$

$\begin{array}{ll}\text { References } & 98\end{array}$

$\begin{array}{ll}\text { CHAPTER } 6 \text { CONCLUSION } & 101\end{array}$

$\begin{array}{ll}\text { Introduction } & 102\end{array}$

How do different societal actors position themselves

with regards to the space given for cultural identity and diversity? 103

$\begin{array}{ll}\text { Which opportunities and barriers do actors encounter } & \\ \text { in different societal spheres and how can these be explained? } & 105\end{array}$

What are the consequences of the findings of the two former

questions for the discourses on integration? 108

$\begin{array}{lr}\text { Research reflection } & 109\end{array}$

$\begin{array}{ll}\text { References } & 110\end{array}$

VALORIZATION ADDENDUM 111

$\begin{array}{ll}\text { SUMMARY } & 115\end{array}$

ZUSAMMENFASSUNG

$\begin{array}{ll}\text { ACKNOWLEDGEMENTS } & 125\end{array}$

$\begin{array}{lr}\text { ABOUT THE AUTHOR } & 127\end{array}$ 


\section{1 \\ Chapter}

\section{Introduction}

Cultural diversity is a rich asset for individuals and societies.

The protection, promotion and maintenance of cultural diversity are an essential requirement for sustainable development for the benefit of present and future generations.

UNESCO Declaration of Cultural Diversity, Art. 6 


\section{CULTURAL DIVERSITY}

Throughout history, people from all quarters of the compass have immigrated to the Netherlands. During the Spanish Inquisition, the Dutch accommodated Sephardic Jews and in the 17th century they opened their borders to Huguenots who were persecuted in France (Van Genugten, 2013). In the 18th century, a group of Ashkenazi Jews settled primarily in Amsterdam as a result of anti-Semitism spreading in Eastern and Central Europe (Lucassen and Penninx, 1994). In the second half of the 20th century, diversity increased once again due to the end of colonization and the post-war economic boom. After Indonesia became independent in 1949, many so-called repatriates came to their homeland $^{1}$. In the 1960s, guest workers from Spain, Italy, and Portugal, and later from Turkey and Morocco came to the Netherlands, followed by subsequent family reunifications. Suriname's independence in 1975 brought new immigrants to the country combined with the arrival of people from the Dutch Antilles in the 1980s (Van Meeteren et al., 2013). The Netherlands additionally received religious and political refugees from Eastern Europe (Schalk-Soekar et al., 2004). Since the 1990s, asylum seekers from Yugoslavia and later from other countries, such as the former Soviet Union, Afghanistan, Sri Lanka, Turkey, Iraq, Iran, Somalia, Angola, and Sierra Leone, arrived in the Netherlands (Van Meeteren et al., 2013). The latest refugees came to the Netherlands in 2014/15 as a consequence of the ongoing war in Syria and Iraq. Since the integration of the European Union, also EU nationals use their freedom of movement to settle in the Netherlands (Van Meeteren et al., 2013). Nowadays, on a total Dutch population of approximately 17 million people about 3.75 million have at least one parent born outside the Netherlands (CBS, 2016).

Immigration enhances diversity in religious denominations, beliefs, ideologies and practices. Presently, about half of the Dutch population belongs to an ecclesiastical or ideological group. A little less than a quarter is Catholic and 16 percent adheres to some form of Protestantism. Six percent declare belonging to another form of religion and about five percent of the Dutch population is Muslim.

According to estimates from 2007, 69\% of the Dutch Muslims is of Turkish or Moroccan decent. Other large groups originate from Suriname, Afghanistan, Iraq, and Somalia. There are also about 12000 Dutch converts (CBS, 2007). Also within the Islamic community, there is a lot of diversity. For example, while most Turks adhere to the Hanafi school of thought, the majority of Moroccan Muslims follows the Maliki school (Ahmad, 2010).

\section{DISCOURSES AND POLICY APPROACHES TO CULTURAL DIVERSITY}

To deal with cultural diversity, various approaches to integration have been applied in the Netherlands throughout history. For the scope of this dissertation, integration functions

\footnotetext{
${ }^{1}$ Inter alia, the Dutch government brought 12.500 Moluccans to the Netherlands in 1951, who had served as soldiers in the Dutch colonial army, but had never been to the Netherlands before (Van Amersfoort, 2004).
} 
as an umbrella term for processes, whereby immigrants become an accepted part of society (Penninx, 2005). ${ }^{2}$ The different approaches to integration may be defined as discourses, as policy approaches, or as social and psychological processes. A certain dominant discourse may however not always translate into respective policies (Modood, 2013, Bertossi, 2011).

\section{Pillarization.}

Between 1900 and the 1960s, a system of pillarization existed in the Netherlands. Pillarization describes a state of segregation, whereby different ideological groups peacefully exist alongside each other. Each pillar has its own institutions and is proportionally subsidized by a common government. Dutch society was consequently separated into different ideological pillars of Protestants, Roman Catholics, socialists and liberals, each with their own schools, media and social environment (Lijphart, 1979). The immigrants, who had arrived since the beginning of the twentieth century did not have their own pillar.

\section{Multiculturalism.}

In the 1960s/70s, a process of secularization and emancipation occurred, leading to the erosion of the pillarized system. Instead, an approach of pragmatic multiculturalism was applied.

Multiculturalism, grounded in the Anglo-Saxon tradition, acknowledges and protects cultural identity and diversity (Rodríguez-García, 2010). The discourse emphasizes the recognition and accommodation of cultural minorities, which are reflected in governmental laws and policies that grant group rights to minorities (Bloemraad et al., 2008, Mitchell, 2004). The enactment of group rights does not replace, but supplement individual rights and anti-discrimination measures (Modood, 2013). While multiculturalism recognizes the need for adherence to the legal system of a society, it opposes universalism (Mitchell, 2004), which assumes that there are universally supported norms and values. Multiculturalism allows groups to express their own cultural ideas and practices as long as they are not contradicting the law. Examples of multiculturalist policies are the inclusion of cultural diversity in school curricula, support for ethnic representation in public media; dual citizenship, and the facilitation of mother-tongue language instruction (Bloemraad, 2007).

Some form of this approach was introduced to the Netherlands with the ethnic minority policy in 1983, even though it was born out of pragmatism rather than ideology. This policy aimed at socio-economic equality, political inclusion and participation, and cultural and religious equity of minorities (Bruquetas-Callejo et al., 2007). It promoted a perception of immigrants as members of an ethnic group rather than as individuals (Entzinger, 2014a). Cultural difference was perceived as an enrichment (Sleegers, 2007).

\footnotetext{
${ }^{2}$ This definition of integration is open regarding the desired end state of integration and the requirements for acceptance (Penninx, 2005).
} 


\section{INTRODUCTION}

\section{Assimilation.}

By 1994, the realization had sunk in that the ethnic minority policy had not shown the desired effects, as unemployment among immigrants remained high; educational achievements of their children were low; and segregation of housing occurred. Thus, a new integration policy was introduced, pushing culture into the private sphere and focused on socio-economic participation instead (Entzinger, 2014b).

In the early 2000s, a shift was observed towards an assimilation discourse in the Netherlands, that also resonated in the integration policies of the early 21st century (Brubaker, 2001, Bruquetas-Callejo et al., 2007, Vasta, 2007, Entzinger, 2006, 2014b).

Assimilation, following the French liberal tradition, is based on the idea that certain norms and values should be shared and respected by everyone in order to maintain social cohesion. Minorities are expected to fully adapt to the norms, values and practices of the dominant majority until they become undistinguishably integrated (Rodríguez-García, 2010, Ager and Strang, 2008). Examples are adaptation regarding clothing, food culture and the celebration of national holidays, but also support for values of the dominant groups regarding gender relations or freedom of religion. The aim of this one-sided process is that minorities create as little disturbance as possible for the majority. Erasing differences and maintaining a colorblind public sphere are seen as successful means to prevent discrimination and conflict (Modood, 2013). Since responsibility for assimilation is assigned to minorities, policies of assimilation mainly concern elimination, or a shift to the local sphere, of social services that aid minorities in their integration process (Mitchell, 2004).

In a news article, social-democrat and sociologist Scheffer (2000) warned that illiberal views of Muslims may undermine the social cohesion of Dutch liberal democracy and accused the political elite of indifference. Meanwhile, the Islam-critical politician, Pim Fortuyn, requested to close the borders for immigrants and he called Islam a backwards religion. The new government, elected in 2003, adopted a tougher stance against immigration, combined with assimilation-focused policies (Entzinger, 2006). Gradually, culture became the defining factor of politics and less attention was drawn to socio-economic problems (WRR, 2007). The greater focus on culture especially concerned Islam, which many Dutch people considered "as the root of all evil" (Entzinger, 2014b, p.700). This perception was fostered by the murder of the film maker Theo van Gogh in 2004, by the political engagement of ex-Muslim and Islam-critic Ayaan Hirsi Ali (2004-2006), and the strong anti-Islam agenda of the Islam-critical Party for Freedom (PVV) since 2006. The government of 2010-12, with tacit support by the PVV, impeded its relationship with the ethnic minorities by dissolving their common structural consultations. The most successful party in the 2017 election used assimilation-related slogans in its campaign, such as act normal or leave. 


\section{Criticisms to multiculturalism and assimilation.}

In the last decades, multiculturalism as well as assimilation received considerable criticism. Koopmans (2010) argues that "multiculturalism may not be beneficial for immigrants, because it may lead to dependence on welfare-state arrangements and thereby to social and economic marginalization" (p.2). It is further suggested that granting a lot of group rights can lead to social segregation (Statham and Koopmans, 2005, Bourne, 2007), which may endanger social cohesion and political stability (Bloemraad, 2007). Indeed, Putnam (2007) suggests that in the short-term, cultural diversity may reduce social solidarity, which may be overcome in the long-term by creating more encompassing identities. Multiculturalism supports the idea of multiple identities. Critics argue that multiple loyalties may create a lack of democratic engagement and commitment to redistribution of wealth. Furthermore, the emphasis on cultural distinctions may attribute more importance to cultural identities than necessary (Bloemraad et al., 2008). Finally, critics argue that culture is depoliticized and becomes a tool for political power. By defining culture as the essential identity of a social being, gender and racial differences and their construction of power receive less attention. It becomes difficult to differentiate between racial stereotypes and cultural differences (Bannerji, 2000).

Assimilation has received considerable criticism for the limited spaces given to cultural diversity. First of all, multiculturalists criticize the complete elimination of cultural diversity up to the private sphere as a lack of recognition of the complexity inherent in cultural pluralism (Rodríguez-García, 2010). Secondly, classical liberalism, the basis of assimilation, is blamed for its focus on equal treatment of all citizens rather than a sense of justice that aims at equal outcomes, such as decent living conditions and self-actualization for everyone (Bloemraad and Wright, 2014). The argument is made that an equal treatment of humans, who are envisioned as freely choosing agents, may perpetuate or even aggravate inequalities (Bloemraad et al., 2008). Ignorance towards ethnicity may increase the civic and political divide between the majority and minority groups, because politics needs collective action. Thirdly, critics challenge the basic assumption that the public sphere can be colorblind and culturally neutral (Taylor, 1997). Instead, they argue that assimilation imposes traditions of the majority on the minorities and in some circumstances even a liberal mono-culturalism occurs (Duyvendak et al., 2007). This is paradoxical, as liberalism is meant to facilitate freedom to think and live differently, but in its extreme form it only allows for a liberal lifestyle. Everybody has to not only tolerate, but embrace liberal values, such as gender equality and homosexuality. Bloemraad et al. (2008) argue that cultural bias in the public sphere may cause inequality regarding rights, belonging, and public participation. For example, defining the weekend in terms of Saturday and Sunday may disadvantage Muslims, whose holy day is on Friday. Finally, failing to publicly recognize minority identities may reinforce stereotypes, because negative labelling of these minorities is left to the private sphere and is not confronted in public (Alexander, 2001). 


\section{INTRODUCTION}

Several scientists have proposed hybrid forms between multiculturalism and assimilations, such as weak multiculturalism, which suggests the recognition of cultural difference in the private sphere, but requires assimilation in the public sphere e.g. regarding education and employment (Grillo, 2007). Bloemraad and Wright (2014) propose inter-culturalism, which entails dialogue based on mutual respect, requests for minorities to adopt liberal values and the dominant common language, and support for diversity and dignity of all members of society. Kymlicka (2012) recommends multiculturalism combined with voluntary civic integration and an open national identity to promote fundamental liberal values of freedom and fairness.

\section{TENSIONS BETWEEN MULTICULTURALISM AND ASSIMILATION}

Nowadays, we experience tensions between those following the multiculturalism discourse and those who have shifted towards a discourse of assimilation. These tensions about the space given to cultural diversity are expressed in public and private debates about issues such as animal welfare vs religious freedom; gender equality and homosexual rights vs religious orthodoxy; and freedom of speech vs blasphemy (BergeaudBlackler, 2007, Havinga, 2010, Zoethout, 2013, Schuh et al., 2012, Korteweg and Yurdakul, 2009, Roggeband and Verloo, 2007, Uitermark et al., 2013, Bracke, 2011). Concrete objects of tensions have been honor killings, ritual slaughter, the construction of mosques, and the headscarf (Zoethout, 2013, Maussen, 2009, Wallet, 2012, Korteweg and Yurdakul, 2009, Saharso and Lettinga, 2008).

Societal reactions to these tensions are perceived discrimination and prejudices, the rise of anti-immigration and anti-Islamic populism, and radicalization among parts of certain minorities (Kloek et al., 2013, Andriessen et al., 2014, Strabac and Listhaug, 2008, Murshed and Pavan, 2011, Doosje et al., 2013, Koopmans and Muis, 2009, Van Kessel, 2011, Vossen, 2012).

Opinions regarding these issues are by no means clearly divided between different cultural groups. For example, while most Dutch people accept homosexuality and gender equality, there are conservative Christian groups that oppose homosexuality and deny pregnant women and elderly people the right to self-determination through respectively abortion or euthanasia. Meanwhile, many members of cultural minorities tolerate homosexuality and support gender equality.

\section{ACTORS IN THE INTEGRATION DISCOURSES}

Besides the government, various actors from the native majority and the ethnic/Islamic minorities are involved with the integration discourses. These actors may operate in different societal spheres, e.g. government, civil society, or the business sector (see Figure 1). 
Each of these spheres has its particular function with regards to integration, and its own mode of operation. The government assumes a legislative, a judicial, and an executive task, thereby drafting and executing laws that define space for cultural identities. The legislative operates on the basis of deliberation and voting to take decisions. The executive implements the enacted laws and the judicial enforces them.

The economy aims at an efficient distribution of goods through a market mechanism matching supply and demand. Many products that ethnic minorities need in order to express their cultural identity are produced and traded in the economy. Market-based private regulation, such as standards and certificates are used to ensure the production and delivery of culturally and religiously adequate products.

Civil society consists of all those actors who do not belong to the government or the business sphere. For example, media fulfills the task of informing citizens about recent events. Through framing information in a specific way, it can affect or perpetuate the dominant public discourse about integration. Civil society organizations facilitate the needs of their members and represent them towards the government and the business sector. The discourse on integration can be influenced top down by the government or bottom up by civil society and the business sector. Furthermore, it is shaped externally by the majority and internality by the minorities. The studies presented in this dissertation have researched actors from the three different spheres involved in external as well as internal discourse.

Figure 1: Actors in the integration discourse

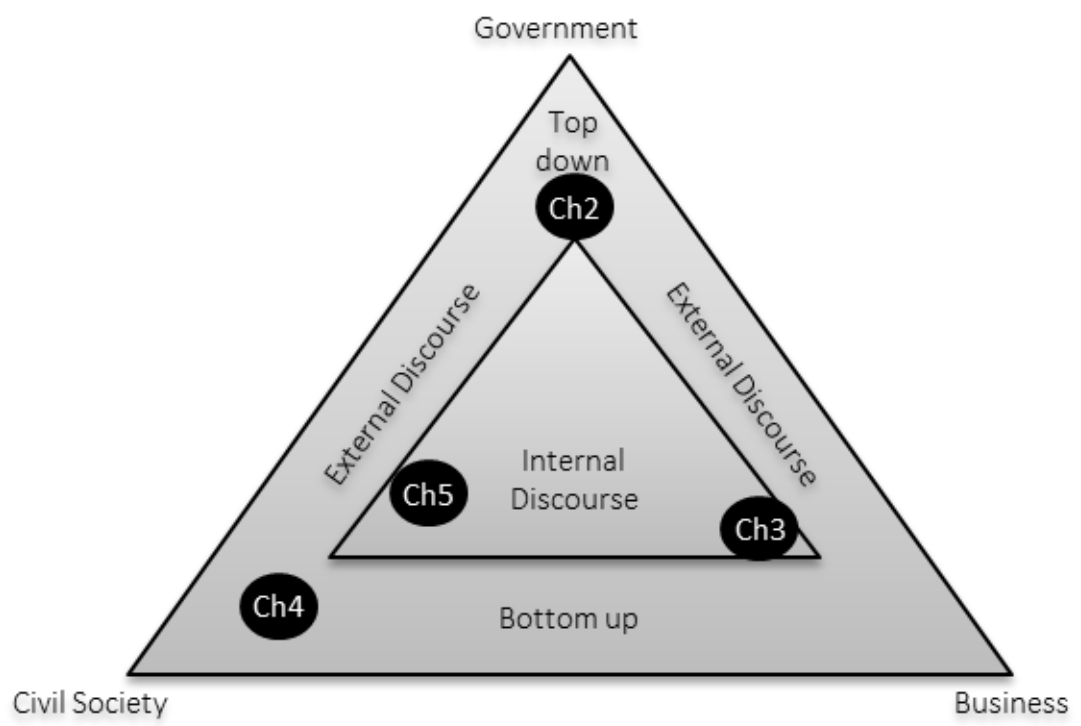




\section{INTRODUCTION}

\section{RESEARCH OBJECTIVE}

This dissertation contributes to the body of knowledge about the tensions between the discourses of multiculturalism and assimilation and the role of different actors therein. It analyzes how actors from different societal spheres position themselves with regards to the space given to cultural diversity. We discover opportunities and barriers in taking a position and elaborate to which extent different societal spheres can contribute to the discourse about assimilation and multiculturalism. The corresponding research questions are:

How do different societal actors position themselves with regards to the space given for cultural identity and diversity?

Which opportunities and barriers do these actors encounter in different societal spheres and how can these be explained?

What are the consequences of the findings of the two former questions for the discourses on integration?

Answers to these questions are of societal and scientific relevance. Especially the changing character of the discourse from multiculturalism towards assimilation makes it interesting to explore how different actors position themselves. If assimilation assigns responsibility for adaptation solely on the minority, it is crucial to understand how these minorities picture their integration process.

One of the premises of a liberal democracy is that people should have the freedom to contribute to public discourse and participate in the political process. For that reason, this dissertation assumes that the incorporation of different perspectives on a level playing field is an important source of legitimacy for a liberal democracy. Identifying opportunities and barriers for the positioning of actors in the different societal spheres can help us to discover power imbalances between actors and alert us to lack of representation. Furthermore, it may allow us to realize the potential for the full inclusion of actors from all societal spheres in the deliberation about integration.

The public discourse of integration influences how people think about the space given to cultural diversity and the expression of cultural identity. The findings of the former questions may help us understand how the discourse will develop in the future and which role the different actors can play in the unfolding discourse and related policies.

\section{METHODS}

Although the different methods used for each study will be described in the separate chapters, here the choice of the methodological approach to this dissertation shall be justified and the relationship between the different methods chosen shall be discussed.

As explained above, the objective of this research is to gain insights into people's perception of reality, the positions they take regarding the space given to cultural diversity, 
and the opportunities and barriers they encounter. Human reasoning is a complex process that takes into account a vast amount of knowledge and feelings to create a standpoint. Thus, instead of discovering one-dimensional cause-effect relationships, this research answers the research questions by mapping different perceptions, positions, and possible explanations. For that reason, the most suitable methodological choice is a social constructivist approach, which assumes that reality does not exist independently from our perception and therefore appears differently to each person in a context dependent fashion (Moses and Knutsen, 2012).

This approach has implications for the methods applied in the data collection and analyzing process. In line with social constructivism, case studies are used for the separate studies included in this dissertation. These are studies of a single instance or several instances to explore the context of a phenomenon. This offers the possibility to execute a holistic and nuanced analysis of a specific situation (Hardwick, 2016) and to delve into the perspective of different actors involved. Data for this research has been collected between 2014 and 2017 and comprises minutes of parliamentary debates, qualitative interviews, strategy reports, certification standards and news items. Part of the qualitative interviews was used for a documentary about halal food for Dutch national television (available at Moslim Omroep, 2015). All of the data collected are representations of people's ideas, standpoints and reasoning.

The analyses executed for these studies include frame analyses, thematic context analyses and a media analysis. Framing is the process of describing a certain situation from a specific angle, thereby emphasizing certain aspects and excluding others. Frames usually entail a problem statement, a preferred solution, and a motivation to act (Snow and Benford, 1988, Benford, 1993). They can be deployed strategically or subconsciously (Shmueli et al., 2006). Frame analysis can be used to analyze how different actors view reality; if different frames oppose each other; and whether frame alignment is possible. Thematic context analysis is used to extract information from data in a systematic manner (Smith, 2000). Media analysis may use either one or a combination of the former methods of analysis to examine media items.

As one of the objectives of this research is to assess what the findings of the different studies mean for the discourse of integration, the relationship between frames and discourse needs to be discussed. A discourse is a coherent narrative compiled of "manifestos, records of debates at meeting, actions of political demonstrators, newspaper articles, slogans, speeches, posters, satirical prints, statues of associations, pamphlets, and so on" (Sewell, 1980, p.9). The recognition that there are several discourses regarding the same issue suggests that there are several opposing systematic views on each topic. Frames can be part of a cultural discourse and sometimes a discourse can be defined as the most general frame (Johnston, 2002). Yet, not only frames influence discourses, but existing discourses also influence which frames are created. Indeed, Reese et al. (2001) found 


\section{INTRODUCTION}

that stakeholders articulate their frame of a situation and then examine the public response. With a positive response, stakeholders intensify their effort and with a negative response they withdraw from debate or change their frame.

\section{CASE STUDIES}

This dissertation focuses on four case studies from the three different societal spheres in order to explore how different actors take a stance with regards to the accommodation of cultural diversity.

In Chapter 2, the debate about the prohibition of non-stunned ritual slaughter in the Dutch Parliament in 2011/2012 is analyzed in order to understand how politicians position themselves amidst the tensions described above. The corresponding research question is:

i. How is cultural diversity expressed in the contestation of value claims regarding non-stunned ritual slaughter and what does this imply for the space given to religious minorities to substantiate their identity?

A frame analysis reveals that tensions exist between minority rights and majority values and with regard to the regulation of religion in the public sphere. The chapter concludes that politicians struggle to position themselves amidst those fundamental questions and certainty is sought in the legal, political, scientific, economic and historical domain. There is no simple answer to the question what determines the space given to religious minorities to substantiate their identities. Although a political majority decision was taken at the end of a long trajectory, this was a compromise that leaves the controversy with its related uncertainties unsolved.

In Chapter 3, Dutch halal regulation serves as a case study from the economic sphere dealing with the needs of the Dutch Muslim community. Within Islam, different interpretations of halal exist and the pluralistic Muslim community requests diverse halal standards. Therefore, adaptive governance arrangements are needed in the halal food market. Globalization and industrialization have complicated the governance of halal food. A complex network of halal governors has developed from the local to the global level. The aim of Chapter 3 is to analyze how the dynamics of the market-driven governance network influence the representativeness of the regulation for the Dutch Muslim community. The corresponding research question is:

ii. To what extent do the halal governors in the Netherlands address the needs of the Muslim community and what is the influence of international halal governance? 
To answer this question, the results of a literature review and eleven qualitative semistructured interviews with the most prominent actors in the Dutch halal governance system are presented. The analysis shows that the halal governance system in the Netherlands is weakly institutionalized and hardly adaptive to the needs of a heterogeneous Muslim community. Improvements are needed concerning stakeholder engagement, transparency, accessibility, impartiality and efficiency.

Chapter 4 examines the influence of the populist movement on Dutch public debate about tolerance and the Islam. Historically, religious tolerance has been an integral part of Dutch identity. Yet, this image has changed due to the emergence of populism in the last 20 years, which has pre-dominantly focused on the stigmatization of Islam. The corresponding research question is:

iii. How has the emergence of populism changed the meaning of tolerance in the public Islam debate?

A thematic content analysis of articles regarding tolerance and Islam in four large Dutch newspapers from November 2004 until December 2015 has been executed. An analytical framework was applied, breaking down the term tolerance in five components: subject of tolerance, object of tolerance, hierarchy of values, power to interfere and limits to tolerance. The results show that while mainstream opinion leaders receive more attention in public debate, populists manage to shape the tolerance discourse. Change has occurred regarding who should practice tolerance and what should be tolerated. The populistic discourse emphasizes contradictions between different values, shapes the hierarchy of values and proposes intolerance for Islamic intolerance as limit of tolerance.

In Chapter 5, different frames of ethnic/Islamic organizations concerning the accommodation of cultural diversity are presented. Assimilation may mean a loss of cultural identity. Therefore, this chapter attempts to understand how ethnic/Islamic organizations respond to the request for assimilation. The corresponding research question is:

iv. How do ethnic/Islamic organizations position themselves regarding the request for assimilation in public discourse?

The research shows that ethnic/Islamic organizations reject the assimilation discourse and they develop post-integration frames concerning socio-economic, political, institutional, cultural, and emotional issues instead. Their limited influence on public discourse may be explained by the current power imbalance between the ethnic/Islamic minorities and Dutch majority, internal incoherence of sub-frames, and a lack of communication.

Chapter 6 discusses the results of the four case studies in the light of the main research question. Important issues regarding the positioning of societal actors are which actors are taking responsibility; the commodification of space for cultural diversity; and path dependency. Several barriers and opportunities arise when actors try to take and express a position and when common ground is sought. The findings allow the definition of possible contributions by each actor involved to the societal discourse on integration. 
Additionally, the last Chapter offers a reflection on the research done for this study and suggests future research questions.

\section{REFERENCES}

AGER, A. \& STRANG, A. 2008. Understanding integration: A conceptual framework. Journal of refugee studies, 21, 166-191.

AHMAD, A. U. F. 2010. Theory and practice of modern Islamic finance: the case analysis from Australia, Universal-Publishers.

ALEXANDER, J. C. 2001. Theorizing the "modes of incorporation": Assimilation, hyphenation, and multiculturalism as varieties of civil participation. Sociological theory, 19, 237-249.

ANDRIESSEN, I., FERNEE, H. \& WITTEBROOD, K. 2014. Ervaren discriminatie in Nederland. Sociaal en Cultureel Planbureau.

BANNERJI, H. 2000. The dark side of the nation: Essays on multiculturalism, nationalism and gender, Canadian Scholars' Press.

BENFORD, R. D. 1993. "You Could Be the Hundredth Monkey": Collective Action Frames and Vocabularies of Motive within the Nuclear Disarmament Movement. The Sociological Quarterly, 34, 195-216.

BERGEAUD-BLACKLER, F. 2007. New Challenges for Islamic Ritual Slaughter: A European Perspective. Journal of Ethnic and Migration Studies, 33, 965-980.

BERTOSSI, C. 2011. National models of integration in Europe: A comparative and critical analysis. American Behavioral Scientist, 55, 1561-1580.

BLOEMRAAD, I. 2007. Unity in diversity? Du Bois Review: Social Science and Research on Race, 4, 317-336.

BLOEMRAAD, I., KORTEWEG, A. \& YURDAKUL, G. 2008. Citizenship and immigration: Multiculturalism, assimilation, and challenges to the nation-state. Annu. Rev. Sociol, 34, 153-179.

BLOEMRAAD, I. \& WRIGHT, M. 2014. "Utter failure" or unity out of diversity? Debating and evaluating policies of multiculturalism. International Migration Review, 48, S292-S334.

BOURNE, J. 2007. In defence of multiculturalism. IRR Briefing Paper, 6.

BRACKE, S. 2011. subjects of debate: secular and sexual exceptionalism, and Muslim women in the Netherlands. Feminist Review, 98, 28-46.

BRUBAKER, R. 2001. The return of assimilation? Changing perspectives on immigration and its sequels in France, Germany, and the United States. Ethnic and racial studies, 24, 531-548.

BRUQUETAS-CALLEJO, M., GARCÉS-MASCAREÑAS, B., PENNINX, R. \& SCHOLTEN, P. 2007. Policymaking related to immigration and integration. The Dutch Case. Amsterdam: IMISCOE Working Papers.

CBS. 2007. Ruim 850 duizend islamieten in Nederland [Online]. Available: http://www.cbs.nl/nl-NL/menu/themas/bevolking/publicaties/artikelen/archief/2007/2007-2278-wm.htm [Accessed 17-12-2015].

CBS. 2016. Bevolking; generatie, geslacht, leeftijd en herkomstgroepering [Online]. Den Haag/Heerlen: Centraal Bureau voor de Statistiek. Available: http://statline.cbs.nl/StatWeb/publication/?VW=T\&DM=SLNL\&PA=37325\&D1=0\&D2=a\&D3=0\&D4=0\&D5=0-4\&D6=|\&HD=110629-

1412\&HDR=G5,T,G3,G2,G4\&STB=G1 [Accessed 09-05-2017].

DOOSJE, B., LOSEMAN, A. \& VAN DEN BOS, K. 2013. Determinants of Radicalization of Islamic Youth in the Netherlands: Personal Uncertainty, Perceived Injustice, and Perceived Group Threat. Journal of Social Issues, 69, 586-604.

DUYVENDAK, J. W., PELS, T. \& RIJKSCHROEFF, R. 2007. A multicultural paradise? The cultural factor in Dutch integration policy.

ENTZINGER, H. 2006. Changing the rules while the game is on: From multiculturalism to assimilation in the Netherlands. In: BODEMANN, Y. M. \& YURDAKUL, G. (eds.) Migration, citizenship, ethnos. Palgrave Macmillan US.

ENTZINGER, H. 2014a. The rise and fall of multiculturalism: The case of the Netherlands. In: JOPPKE, C. \& MORAWSKA, E. (eds.) Toward assimilation and citizenship: Immigrants in liberal nation-states. Palgrave Macmillan UK. 
ENTZINGER, H. 2014b. The growing gap between facts and discourse on immigrant integration in the Netherlands. Identities, 21, 693-707.

GRILLO, R. 2007. An excess of alterity? Debating difference in a multicultural society. Ethnic and Racial Studies, 30, 979-998.

HARDWICK, S. W. 2016. Case Study Approach. International Encyclopedia of Geography: People, the Earth, Environment and Technology. John Wiley \& Sons, Ltd.

HAVINGA, T. 2010. Regulating halal and kosher foods: different arrangements between state, industry and religious actors. Erasmus Law Review, 3, 241.

JOHNSTON, H. 2002. Verification and proof in frame and discourse analysis. In: KLANDERMANS, B. \& STAGGENBORG, S. (eds.) Methods of social movement research. Minneapolis: University of Minnesota Press.

KLOEK, M. E., PETERS, K. \& SIJTSMA, M. 2013. How Muslim Women in The Netherlands Negotiate Discrimination During Leisure Activities. Leisure Sciences, 35, 405-421.

KOOPMANS, R. 2010. Trade-Offs between Equality and Difference: Immigrant Integration, Multiculturalism and the Welfare State in Cross-National Perspective. Journal of Ethnic and Migration Studies, 36, 1-26.

KOOPMANS, R. \& MUIS, J. 2009. The rise of right-wing populist Pim Fortuyn in the Netherlands: A discursive opportunity approach. European Journal of Political Research, 48, 642-664.

KORTEWEG, A. \& YURDAKUL, G. 2009. Islam, gender, and immigrant integration: Boundary drawing in discourses on honour killing in the Netherlands and Germany. Ethnic and Racial Studies, 32, 218-238.

KYMLICKA, W. 2012. Multiculturalism. Social Justice and the Welfare State, in: Gary Craig/David Gordon/Tania Burchardt, 53-75.

LIJPHART, A. 1979. Verzuiling, pacificatie en kentering in de Nederlandse politiek, Amsterdam, J. H. de Bussy.

LUCASSEN, J. \& PENNINX, R. 1994. Nieuwkomers, nakomelingen, Nederlanders: immigranten in Nederland 15501993, Amsterdam, Het Spinhuis.

MAUSSEN, M. J. M. 2009. Constructing mosques: The governance of Islam in France and the Netherlands.

MITCHELL, K. 2004. Geographies of identity: multiculturalism unplugged. Progress in human geography, 28, 641-651.

MODOOD, T. 2013. Post-immigration 'difference'and integration. Meritum, revista de Direito da Universidade FUMEC, 8.

MOSES, J. \& KNUTSEN, T. 2012. Ways of knowing: competing methodologies in social and political research, Palgrave Macmillan.

MOSLIM OMROEP. 2015. Hoe halal is Halal? [Online]. Available: http://www.npo.nl/mo-doc-hoe-halal-ishalal/28-06-2015/VPWON_1244711 [Accessed 10-07-2015].

MURSHED, S. M. \& PAVAN, S. 2011. Identity and Islamic Radicalization in Western Europe. Civil wars, 13, 259279.

PENNINX, R. 2005. Integration of migrants: Economic, social, cultural and political dimensions. In: MACURA, M., MACDONALD, A. L. \& HAUG, W. (eds.) The new demographic regime: Population challenges and policy responses. Geneva: United Nations.

PUTNAM, R. D. 2007. E pluribus unum: Diversity and community in the twenty-first century the 2006 Johan Skytte Prize Lecture. Scandinavian political studies, 30, 137-174.

REESE, S. D., GANDY JR, O. H. \& GRANT, A. E. 2001. Framing public life: Perspectives on media and our understanding of the social world, Routledge.

RODRÍGUEZ-GARCÍA, D. 2010. Beyond Assimilation and Multiculturalism: A Critical Review of the Debate on Managing Diversity. Journal of International Migration and Integration 11, 251-271.

ROGGEBAND, C. \& VERLOO, M. 2007. Dutch women are liberated, migrant women are a problem: The evolution of policy frames on gender and migration in the Netherlands, 1995-2005. Social policy \& administration, 41, 271-288.

SAHARSO, S. \& LETTINGA, D. 2008. Contentious citizenship: Policies and debates on the veil in the Netherlands. Social Politics: International Studies in Gender, State \& Society, 15, 455-480. 


\section{INTRODUCTION}

SCHALK-SOEKAR, S. R. G., VAN DE VIJVER, F. J. R. \& HOOGSTEDER, M. 2004. Attitudes toward multiculturalism of immigrants and majority members in the Netherlands. International Journal of Intercultural Relations, 28, 533-550.

SCHEFFER, P. 2000. Het multiculturele drama. nrc Handelsblad.

SCHUH, C., BURCHARDT, M. \& WOHLRAB-SAHR, M. 2012. Contested Secularities: Religious Minorities and Secular Progressivism in the Netherlands. Journal of Religion in Europe, 5, 349-383.

SEWELL, W. H. 1980. Work and revolution in France: The language of labor from the Old Regime to 1848, Cambridge University Press.

SHMUELI, D., ELLIOTT, M. \& KAUFMAN, S. 2006. Frame changes and the management of intractable conflicts. Conflict Resolution Quarterly, 24, 207-218.

SLEEGERS, F. 2007. In debat over Nederland. Veranderingen in het discours over de multiculturele samenleving en nationale identiteit. Amsterdam: Wetenschappelijke Raad voor het Regeringsbeleid.

SMITH, C. P. 2000. Content analysis and narrative analysis. In: REIS, H. T. \& JUDD, C. M. (eds.) Handbook of Research Methods in Social and Personality Psychology. Cambridge: Cambridge University Press.

SNOW, D. A. \& BENFORD, R. D. 1988. Ideology, frame resonance, and participant mobilization. International social movement research, 1, 197-217.

STATHAM, P. \& KOOPMANS, R. 2005. Problems of Cohesion? Multiculturalism and Migrants' Claims-Making for Group Demands in Britain and the Netherlands. Comparative European Research in Migration, Diversity and Identities, 69.

STRABAC, Z. \& LISTHAUG, O. 2008. Anti-Muslim prejudice in Europe: A multilevel analysis of survey data from 30 countries. Social Science Research, 37, 268-286.

TAYLOR, C. 1997. The politics of recognition. In: HEBLE, A., PENNEE, D. P. \& STRUTHERS, T. (eds.) New contexts of Canadian criticism. Ontario, Canada: Broadview Press.

UITERMARK, J. L., MEPSCHEN, P. \& DUYVENDAK, J. W. 2013. Populism, Sexual Politics, and the Exclusion of Muslims in the Netherlands. In: BOWEN, J., BERTOSSI, C., DUYVENDAK, J. W. \& KROOK, M. L. (eds.) European States and Their Muslim Citizens. The Impact of Institutions on Perceptions and Boundaries. Cambridge: Cambridge University Press.

VAN AMERSFOORT, H. 2004. The waxing and waning of a diaspora: Moluccans in the Netherlands, 1950-2002. Journal of Ethnic and Migration Studies, 30, 151-174.

VAN GENUGTEN, S. 2013. The Netherlands and Islam: In Defence of Liberalism and Progress? The International Spectator, 48, 72-85.

VAN KESSEL, S. 2011. Explaining the electoral performance of populist parties: The Netherlands as a case study. Perspectives on European Politics and Society, 12, 68-88.

VAN MEETEREN, M., VAN DE POL, S., DEKKER, R., ENGBERSEN, G. \& SNEL, E. 2013. Destination Netherlands. History of immigration and immigration policy in the Netherlands. Netherlands. Economic, Social and Environmental Issues.

VASTA, E. 2007. From ethnic minorities to ethnic majority policy: Multiculturalism and the shift to assimilationism in the Netherlands. Ethnic and racial studies, 30, 713-740.

VOSSEN, K. 2012. Van marginaal naar mainstream? Populisme in de Nederlandse geschiedenis. BMGN-LoW Countries Historical Review, 127.

WALLET, B. 2012. Ritueel slachten en godsdienstvrijheid in een seculiere samenleving. Religie \& Samenleving, 7, 166-183.

WRR 2007. Identificatie met Nederland, Amsterdam University Press.

ZOETHOUT, C. M. 2013. Ritual Slaughter and the Freedom of Religion: Some Reflections on a Stunning Matter. Human Rights Quarterly, 35, 651-67 


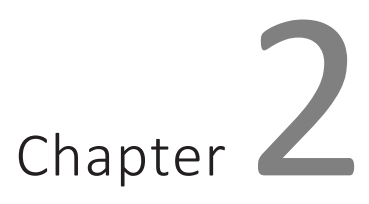

\section{Dealing with tensions of multiculturalism: The politics of ritual slaughter in the Netherlands}

This product is a compromise,

and the nature of compromise is that you don't get everything you want.

Conrad Burns, former US senator 


\section{ABSTRACT}

This chapter deals with the question how cultural diversity, expressed in a parliamentary debate, can influence the space given to religious minorities to substantiate their identity. The debate about the prohibition of non-stunned ritual slaughter in the Dutch parliament in 2011/12 serves as case study. A frame analysis reveals that tensions exist between minority rights and majority values and with regard to the regulation of religion in the public sphere. The chapter concludes that politicians struggle to position themselves amidst those fundamental questions and certainty is sought in the legal, political, scientific, economic and historical domain. There is no simple answer to the question what determines the space given to religious minorities to substantiate their identities. Although a political majority decision was taken at the end of a long trajectory, this was a compromise that leaves the controversy with its related uncertainties unsolved.

Published as:

KURTH, L. \& GLASBERGEN, P. 2015. Dealing with tensions of multiculturalism: The politics of ritual slaughter in the Netherlands. European Journal of Cultural Studies. 


\section{INTRODUCTION}

Traditionally, food practices are linked with the expression of cultural identity. Through these practices, groups can distinguish themselves from others (Fischler, 1988, Mintz and Du Bois, 2002) and "reinforce their sense of belonging" (Cantarero et al., 2013, p.881). Immigrants reconnect with their original culture through the consumption of traditional food (Weller and Turkon, 2015). In the European context, the claim of Muslims and other minorities to experience their own cultural identity through their food practices is generally accepted if they are in line with the laws of the particular country (Lerner and Rabello, 2006). Nevertheless, the religious convictions on which these practices are often based may conflict with other, particularly secular values. In such cases, tolerance regarding cultural diversity may come under pressure and minority food practices may become a challenge through which criticisms against multiculturalism manifest themselves.

This chapter aims to illustrate and grasp these food-related tensions of multiculturalism with a study in a specific problem field and context. The problem field concerns the conflicting values within the debate over ritual slaughter. Ritual slaughter, as a practice of meat production for Islamic and Jewish consumers, is based on a complex set of rules, wherein the animal's neck is cut with a sharp knife, a prayer is said and the animal exsanguinates (for more detailed information see Regenstein et al., 2003). Research has shown that controversies exist over the effect of non-stunned ritual slaughter on animal welfare (Grandin and Regenstein, 1994, Rosen, 2004, Kijlstra and Lambooij, 2008, Von Holleben et al., 2010, Cenci-Goga et al., 2013) and the necessity and permissibility of stunning methods in Islam (Nakyinsige et al., 2013, Salamano et al., 2013, Van Waarden and van Dalen, 2013, Velarde et al., 2014). Moreover, it has been discussed whether and how non-stunned ritual slaughter should be covered by national and international law (Wohlrab-Sahr, 2004, Lerner and Rabello, 2006, Bergeaud-Blackler, 2007, Smith, 2007, Levine, 2011, Zoethout, 2013) and how political actors dealt with the issue in past and current debates (Havinga, 2008, Wallet, 2012).

The context of this study is the Dutch parliamentary debate. The Netherlands has long been pictured as a tolerant society. However, since the turn of the century the public and political debate has shifted from framing multiculturalism as societal enrichment towards a critical attitude regarding cultural diversity. This new discourse is charged with emotions over the challenges of multiculturalism and the uptake of these emotions by national populists and opinion leaders. The latter anticipate tensions between the idealtypical Dutch national values, e.g. modern, western, open, tolerant and individualistic, and non-western values, particularly of the Islamic minority (Sleegers, 2007). These tensions manifested themselves in the fierce debate over the prohibition of non-stunned ritual slaughter between 2008 and 2012. A bill handed in by the animal rights party led to a parliamentary debate about the protection of animal rights versus the right of religious minorities to execute their religious practices. While the Lower House voted in favor 
of a ban of non-stunned ritual slaughter in an amended form, this decision was later rejected by the Upper House.

In this chapter the parliamentary debate will be analyzed in order to answer the question: How is cultural diversity expressed in the contestation of value claims regarding nonstunned ritual slaughter and what does this imply for the space given to religious minorities to substantiate their identity?

This question will be answered using a frame-critical policy analysis. This type of analysis is used to identify a policy controversy, construct competing frames and specify the forum of the discourse (Rein and Schön, 1996). Frames are constructs of meaning that represent value claims and steer policy discourse. Through examining contradicting frames, their interactions and the development of dominant frames, decision making processes can better be understood and conclusions can be drawn about the space given to diverse expressions of identity.

The next section further elaborates on frame analysis and the methods of data collection used for this research. Thereafter, the frames used in the parliamentary debate at different points in time are illustrated and the frame changes are explained. The conclusion elaborates how different political actors try to position themselves towards minority rights in general and the right of religious freedom specifically.

\section{METHODOLOGY}

Framing is the process of painting a picture of a certain issue, thereby emphasizing some parts of the reality "in such a way as to promote a particular problem definition, causal interpretation, moral evaluation, and/or treatment recommendation" (Entman, 1993, p.52). In other words, framing entails the identification of a problem, a proposal of a solution and a motivation for individuals to act (Snow and Benford, 1988, Benford, 1993). It is an inherently normative process that can either be used subconsciously to simplify and organize complex realities or strategically to advance one's interest (Shmueli et al., 2006).

Public policies depend on framing because they are constructs of problems and corresponding solutions that are inherently selective and normative (Scholten, 2011). Politicians use issue framing, which "refers to the meanings attached to agenda items, events or problems in the relevant domain or context" (Dewulf et al., 2009, p.165). They draw a picture of a certain policy issue, thereby defining the problem in normative terms and promoting specific policy measures while precluding others. Through this process they promote their own preferred policy option (Campbell, 2002). A policy debate may entail parties with contradicting strategic frames. Yet, these frames may change during a policy debate, since the construction of meaning is not static, but unfolds through interaction (Van Hulst and Yanow, 2014). However, in a situation where the option of frame change is limited, "the scope for reflection is overly constrained, and when the contest reaches deeply symbolic meaning within society" (Rein and Schön, 1996, p.95), an intractable policy controversy may arise. This may lead to a dialogue of the deaf, when politician cannot 
understand each other due to a fundamental disagreement on the problem definition and the measures to be taken (Scholten, 2011). In a liberal democracy, a diversity of frames is valued, but in a system with majority decisions on bills, the most dominant frames may affect the policy options considered by politicians and the outcome of the policy making process. Since policy measures may influence the space given to minorities to express their identity, it is crucial to assess frames as representations of value claims, how frame change occurs and why certain frames become dominant.

The frame-critical policy analysis of this study is based on a thematic content analysis. Content analysis is a method used to systematically extract information from data in order to identify specific characteristics of its content (Smith, 2000). A thematic content analysis focuses on certain themes within the material. The debate about ritual slaughter in Dutch parliament was analyzed in order to determine its most prominent themes. The first step was the identification of the most important data sources. These consisted of the transcribed minutes and videos of all parliamentary debates open to the public, all official motions, amendments to the bill and the official letter exchange as provided by the Dutch online archive for public announcements between September 2008 and June 2012. In a second step, the resulting 453 documents were assessed manually regarding duplicates and their actual relevance to the debate and 29 documents were chosen for an initial inductive coding. Inductive coding involves reading the material with an open attitude and little pre-

Table 1: Overarching coding themes

Animal welfare

Relativity of the problem

Meat labeling

Meat Export

NIMBY Effect

Policy Problem

Religious Freedom

Role of Science

Conventions \& Constitution

Participation

Culture

Technical Process

Integration Problem conditions in order to reveal possible frames (Semetko and Valkenburg, 2000). The software Max QDA was used, which allowed for a simplified comparison and clustering of codes. Every paragraph received an individual code that represented its major content. From the variety of codes thirteen overarching themes were identified (Table 1) that played a major role in the debate.

In the fourth step, these themes were used to develop a deductive code list which was employed to execute the inclusive coding. Only the transcribed minutes of the official debates $^{1}$ in the Lower House and the Upper House ${ }^{2}$ were used for the inclusive coding and each political party received a separate set of codes. From the codes, frames were

${ }^{1}$ (Tweede Kamer (Lower House of the Dutch Parliament), 2011a, Tweede Kamer (Lower House of the Dutch Parliament) 2011b, Tweede Kamer (Lower House of the Dutch Parliament), 2011c, Eerste Kamer (Upper House of the Dutch Parliament), 2011b, Eerste Kamer (Upper House of the Dutch Parliament), 2012).

2 The Dutch legislature is bicameral and consists of a Lower and an Upper House. Both Houses have the right to assess the budget plan, to submit motions, to interpellate and ask questions, and to demand for surveys and investigation. The Lower House additionally has the right to amend bills and to propose new legislation. Bills always have to pass the Lower House before entering the Upper House (ProDemos, 2012). 
developed at three points in time for each party. Parties with overlapping frames were taken together and overall frames were developed, organized around the central disputed themes of debate. These frames are static representations of the meaning constructed. In order to explain the shift in frames, qualitative interviews were conducted with eight of the party representatives ${ }^{3}$ that took part in the debate and two representatives of the Jewish and Muslim communities in the Netherlands.

\section{FRAME ANALYSIS OF THE DUTCH POLITICAL DEBATE ABOUT RITUAL SLAUGHTER}

While the animal rights party holds only two seats in parliament, its bill caused a major debate in Dutch Parliament and in an amended form gained a majority in the Lower House. The bill proposed the removal of an exemption from obligatory pre-stunning for Israelite and Islamic ritual slaughtering from former Article 44 of the health and welfare law for animals (Tweede Kamer, 2008). Due to the filing of the bill as an amendment of an agricultural law, it was announced through the minister of agriculture, nature and food quality. In the usual process of law making in the Netherlands the bill was sent to the Council of State (COS), the official advisory body to the parliament, which assesses bills, but cannot give binding advice. Its major conclusions were that the bill forms a limitation to religious freedom, conflicting with Article 6.1 of the Dutch constitution ${ }^{4}$ and Article 9 of the European Convention on Human Rights $(E C H R)^{5}$. Furthermore, the CoS "did not consider the infringement to animal welfare as such a pressing social need that it justifies an unconditional ban on ritual slaughter" (Raad van State, 2008, no page). Yet, after debates in the Lower House in February, April and June 2011 the amended bill was accepted with a majority of 116 against 30 votes (Tweede Kamer, 2011f). In June 2012 the Upper House, however, rejected the bill inter alia using the arguments of the CoS. Instead, a covenant was concluded by the Dutch government, religious organizations and the organization of slaughter houses and meat producing companies. It involved arrangements

\footnotetext{
${ }^{3}$ From the Lower House: Staatskundig Gereformeerde Partij (Christian conservative party), the animal rights party, the right-wing nationalist party; from the Upper House: the social democratic party, the conservative liberal party, the social liberal party, Christen Democratisch Appèl, ChristenUnie (Christian conservative parties) ${ }^{4}$ The Constitution of the Kingdom of the Netherlands 2008: "Article 6: 1. Everyone shall have the right to profess freely his religion or belief, either individually or in community with others, without prejudice to his responsibility under the law. 2. Rules concerning the exercise of this right other than in buildings and enclosed places may be laid down by Act of Parliament for the protection of health, in the interest of traffic and to combat or prevent disorders" (Government of The Netherlands, 2012).

${ }^{5}$ ECHR, 1950, Art. 9, "Freedom of thought, conscience and religion: 1. Everyone has the right to freedom of thought, conscience and religion; this right includes freedom to change his religion or belief and freedom, either alone or in community with others and in public or private, to manifest his religion or belief, in worship, teaching, practice and observance. 2. Freedom to manifest one's religion or beliefs shall be subject only to such limitations as are prescribed by law and are necessary in a democratic society in the interests of public safety, for the protection of public order, health or morals, or for the protection of the rights and freedoms of others" (Council of Europe, 1950).
} 
concerning the improvement of animal welfare, education of slaughterers, the initiation of a scientific advisory commission, and the supervision of slaughter houses.

The debate about ritual slaughter triggered emotions and touched upon various complex and interrelated topics. Some were unanimously agreed upon while others led to diverging frames. All parties agreed that animals should not undergo unnecessary suffering during the slaughter process. Moreover, they acknowledged that ritual slaughter represents only a small share of the Dutch meat production compared to intensive meat production processes, whose practices are frequently criticized. It was also mutually agreed that the current meat labelling practices are not sufficiently informing the consumer. The export of non-stunned meat was criticized as drastically increasing the scale of Dutch non-stunned meat production. Finally, all parties acknowledged that a prohibition of non-stunned ritual slaughter may shift production to neighboring countries or to the black market, although the animal rights party was less explicit about this issue than other parties. Since these points were unanimously agreed upon, they will not be addressed in the frame analysis. The focus will rather be on the more controversial topics and how the framing of those topics changed throughout the debate. The major controversy was whether animal welfare and religious views on ritual slaughter are compatible. Within the framework of this question, fiercely debated topics were the significance of religious freedom and animal welfare, the use of science, the compliance of the draft bill with the ECHR as well as the Dutch constitution, and the participation of religious groups in decision making.

\section{Original frames of the Lower House.}

A total of 10 parties ${ }^{6}$ participated in the first term of the debate on 17 February 2011 and 13 April 2011. Four frames were identified from an analysis of the speeches of their spokespersons.

Religious Freedom Fighter. The Christian conservative parties gave priority to religious freedom above animal welfare. They agreed with the need for improvement in animal welfare, but not at the cost of the Jewish tradition in Europe. Due to many alternative improvement options, they considered the bill a disproportional restriction to religious freedom and therefore in conflict with the ECHR and the Dutch constitution. In their view, religious groups should have the freedom to interpret their religion independently and to execute their religious duties. The decision about the bill should be based on moral considerations, especially in the absence of scientific consensus. Moreover, the Christian conservatives argued that "one should speak with religious minorities and not about them" (Tweede Kamer, 2011a: 54-4-5, CDA).

\footnotetext{
${ }^{6}$ Christen Democratisch Appèl, ChristenUnie, Staatskundig Gereformeerde Partij $=$ Christian conservative parties; Partij van de Arbeid = social democratic party; Volkspartij voor Vrijheid en Democratie = conservative liberal party; Democraten 66 = social liberal party; Partij Voor de Vrijheid = right wing nationalist party; Partij voor de Dieren = animal rights party; Groenlinks = green party; Socialistische Partij = socialist party
} 


\section{DEALING WITH TENSIONS OF MULTICULTURALISM}

Compromise Seeker. The social democratic party and the conservative liberal party were initially indecisive. They saw the need for ritually slaughtered meat in religious communities, but they also recognized new alternatives and agreed that "religious freedom does not give anyone the right to inflict unnecessary suffering on animals" (Tweede Kamer, 2011a: 54-4-29, PvdA). They would have liked to see a compromise, reducing animal suffering without restricting religious freedom. Both found no scientific consensus about animal suffering and they were unsure how the bill would relate to national and international law. Yet, they emphasized that the inclusion of religious groups in the decisionmaking process would be an important step forward.

Animal Activist. The socialist party, the green party, the animal rights party and the social liberal party prioritized animal welfare above religious freedom. They found that religious groups should have the freedom to execute their religion within the established norms of animal welfare. Animals should not suffer additional pain due to religious convictions and "it should not make a difference for the animal whether its slaughterer is Jewish, Muslim, Christian or secular" (Tweede Kamer, 2011a: 54-4-28, D66). That nonstunned ritual slaughter leads to unnecessary additional pain for animals was seen as a scientific fact. They argued against a breach of the bill with the ECHR and the Dutch Constitution because "the state can restrict religious freedom on the basis of public order, security and morality" (Tweede Kamer, 2011a: 54-4-27, D66). Participation of religious groups in decision making was rejected, because it had not led to fruitful results in the past and only prolonged animal suffering. It was, however, seen as valuable for the implementation of the prohibition.

Multiculturalism Critics. The right-wing nationalist party wanted to prohibit all rituals during slaughtering, arguing that the animals may suffer from the presence of an Imam and music played during the slaughtering ceremony. They framed the Netherlands as a civilized country where backwards traditions should not be accepted. "In some countries, religions and ideologies people are stoned or hanged. (...) You cannot just say: They think differently about it, thus it is allowed here as well. In our countries animals are not being mistreated or tortured" (Tweede Kamer, 2011a: 54-4-13, PVV). According to them, scientific consensus existed that ritual slaughter leads to additional animal suffering, if only Dutch reports were taken into account instead of scientific reports from countries with worse animal welfare conditions. Therefore, they rejected foreign research reports concerning the issue. A summary of the frames can be found in Table 2. 
Table 2: Frames Lower House 1st term

\begin{tabular}{|c|c|c|c|c|c|c|}
\hline Prame & $\begin{array}{c}\text { Religious } \\
\text { Freedom } \\
\text { Priority }\end{array}$ & $\begin{array}{c}\text { Animal } \\
\text { Welfare } \\
\text { Priority }\end{array}$ & $\begin{array}{c}\text { Scientific } \\
\text { Consensus }\end{array}$ & $\begin{array}{c}\text { Draft Bill } \\
\text { Accepted }\end{array}$ & $\begin{array}{c}\text { ECHR \& Dutch } \\
\text { Constitution } \\
\text { Satisfied }\end{array}$ & $\begin{array}{c}\text { Participation } \\
\text { Needed }\end{array}$ \\
\hline $\begin{array}{c}\text { Religious Freedom } \\
\text { Fighter }\end{array}$ & Yes & No & No & No & No & Yes \\
\hline $\begin{array}{c}\text { Compromise } \\
\text { Seeker }\end{array}$ & Partly & Partly & No & Partly & Partly & Yes \\
\hline $\begin{array}{c}\text { Animal Activist } \\
\text { No }\end{array}$ & Yes & Yes & Yes & Yes & No \\
\hline $\begin{array}{c}\text { Multiculturalism } \\
\text { Critics }\end{array}$ & No & Yes & Yes & Partly & Unknown & Unknown \\
\hline
\end{tabular}

\section{Changing frames in the Lower House.}

The second term of the debate was scheduled on 22 June 2011, just after a roundtable debate with different interest groups, such as religious movements and scientists, and few days before the voting about the bill. In the meantime, two amendments had been submitted. The Christian conservative parties proposed the preservation of the exemption for non-stunned ritual slaughter, but applying stricter rules of which the most debated ones were a maximum time of animal consciousness of 45 seconds after slaughtering and the reintroduction of slaughter permits depending on demand (Tweede Kamer, 2011d). The green party, the social liberal party, the social democratic party and the conservative liberal party proposed to include the possibility of exemption if religious groups could prove scientifically that their slaughter methods would not create more animal suffering than regular slaughter methods (Tweede Kamer, 2011e). These two amendments reflect the change of frames that had taken place between the two debates. The constellation of parties had changed, as well as the scale of polarization (see Table 3). Whereas in the first term of debate, there was a division between the Christian parties, the left-wing parties, and the right-wing nationalist party, leaving the social democrats and conservative liberals indecisive in in the middle, the second term of debate revealed a different picture.

Compromise Seekers. The previously indecisive parties joined the camp of the green party and the social liberals, which argued for animal rights above religious freedom, but became more moderate throughout the debate with regard to the recognition of religious rights. They assumed the presence of scientific consensus that non-stunned ritual slaughter leads to additional animal suffering, but saw a need for participation of religious groups in order to create animal welfare in ritual slaughter practices. The joint votes of 
these parties created majority support for the bill with their amendment. Different explanations for the shift in framing and the changing constellation of parties have been offered by the interviewees. According to the representative of the animal rights party, the previously indecisive parties got convinced by the scientific reports which showed that ritual slaughter inflicts additional suffering on animals, which was used to legitimize the limitation of religious freedom. The ECHR provides for a limitation if it is in "the interests of public safety, for the protection of public order, health or morals, or for the protection of the rights and freedoms of others" (Council of Europe, 1950, no page). On the basis of a poll among the Dutch population, the animal rights party concluded that animal welfare is part of Dutch morality and prevails above religious freedom. The representative of right wing nationalist party explained the change of frame as a reaction to popular pressure, since the majority of the population supported the bill. Moreover, he saw the protection of Christian values as an additional possible motivation. The representative of the conservative liberal party in the Upper House explained the shift of frames in the Lower House by political opportunism, populist, laconic and superficial handling of the debate without thinking about the consequences for minorities in society. One of the Christian conservative parties argued that the rejection of involvement of religious groups in the debate at the Lower House had increased the bias towards animal welfare. The social liberal party's representative from the Upper House argued that the growing publicity through e.g. "the use of a terrifying movie and the shared animal welfare objectives of his colleagues in the Lower House strongly influenced the political momentum that led to support for the amended bill". The moderation of the original bill by means of amendments was explained through the growing lobby by religious organizations and the pressure of the constituency.

Religious Freedom Fighter. The Christian parties that kept their alliance became more moderate in their pursuit to preserve religious freedom and made concrete proposals to increase animal welfare. They rejected the bill mainly in the light of the preservation of religious freedom and welcomed the participation of religious groups in decision making. Due to their own beliefs and in the light of European history they understood the religious feelings of Jews and Muslim's against the prohibition. Moreover, they perceived a lack of scientific evidence for the additional suffering of animals during non-stunned ritual slaughter. The moderation of these parties as expressed by their amendment was explained by their personal engagement with animal welfare and the Christian concept of guardianship for nature and all living beings. They acknowledged that ritual slaughter could lead to unacceptable suffering of large and heavy animals and therefore tried to limit the slaughter practice to small animals.

Animal Activists \& Multiculturalism Critics. The socialist party, the animal rights party and the right-wing nationalist party were less willing to make concessions. All three rejected the amendment by the Christian conservative parties and the latter two also saw no added value in including an exemption to the prohibition, yet voted in favor of the 
amended bill. The animal rights party rejected the participation of religious groups in decision making, because previous negotiations had not led to the desired results. The rightwing nationalist party argued that people are being fooled by the amendment to the bill and again plead for a total prohibition of all kinds of ritual slaughter. Their representative found that ritual slaughter should be prohibited on the basis of scientific proof that it inflicts additional suffering on animals. He therefore rejected the participation of religious groups in decision making, as they may not be scientists with Dutch norms and values.

Table 3: Frames Lower House 2nd term

\begin{tabular}{|l|c|c|c|c|c|c|c|}
\hline Preference & $\begin{array}{c}\text { Religious } \\
\text { Freedom } \\
\text { Priority }\end{array}$ & $\begin{array}{c}\text { Animal } \\
\text { Welfare } \\
\text { Priority }\end{array}$ & $\begin{array}{c}\text { Scientific } \\
\text { Consensus }\end{array}$ & $\begin{array}{c}\text { Exemption } \\
\text { Amend- } \\
\text { ment }\end{array}$ & $\begin{array}{c}\text { Prohibition } \\
\text { Amend- } \\
\text { ment }\end{array}$ & $\begin{array}{c}\text { ECHR \& } \\
\text { Dutch con- } \\
\text { stitution } \\
\text { Satisfied }\end{array}$ & $\begin{array}{c}\text { Participation } \\
\text { Integrated }\end{array}$ \\
\hline $\begin{array}{l}\text { Religious Free- } \\
\text { dom Fighter }\end{array}$ & Yes & Partly & No & Yes & No & No & Yes \\
\hline $\begin{array}{l}\text { Compromise } \\
\text { Seeker }\end{array}$ & Partly & Yes & Yes & No & Yes & Yes & Yes \\
\hline Animal Activist & No & Yes & Yes & No & Partly & Yes & No \\
\hline $\begin{array}{l}\text { Multiculturalism } \\
\text { Critics }\end{array}$ & No & Yes & Yes & No & Partly & Unknown & No \\
\hline
\end{tabular}

The lengthy debate in the Lower House resulted in the adoption of the bill with an amendment that included the possibility of exemption if religious groups could prove scientifically that their slaughter methods did not create more animal suffering than regular slaughter methods. In accordance with the Dutch constitution, the bill was then presented to the Upper House, whose primary task is the examination of a bill's quality, its accordance with the constitution and international treaties, that the rights of the citizens are not infringed and whether the implementation is financially feasible (Eerste Kamer, no date).

\section{Frame Change in the Upper House.}

In the Upper House, there was a different constellation of parties with the same frame, as certain parties disagreed with their peers from the Lower House. Whereas in the Lower House four major frames have been identified that changed in composition and of which the majority became more moderate in their pursuits, in the Upper House only two frames were identified. On the one hand, there were the Christian conservative parties, the social liberal party, the social democratic party and the conservative liberal party who 
doubted the accordance of the bill with the Dutch constitution and the ECHR and its technical applicability. For them religious freedom received the priority above animal welfare. Yet, they agreed that animal welfare should be improved and therefore supported the proposal of a covenant with the religious groups and the slaughter houses. They blamed the supporters of the bill of ethical absolutism and feared a disintegration of a minority from Dutch society.

Table 4: Frames Upper House

\begin{tabular}{|c|c|c|c|c|c|c|c|}
\hline Preference & $\begin{array}{c}\text { Religious } \\
\text { freedom } \\
\text { Priority }\end{array}$ & $\begin{array}{c}\text { Animal } \\
\text { welfare } \\
\text { Priority }\end{array}$ & $\begin{array}{c}\text { Scientific } \\
\text { Consensus }\end{array}$ & $\begin{array}{c}\text { ECHR \& } \\
\text { Dutch } \\
\text { constitution } \\
\text { Satisfied }\end{array}$ & $\begin{array}{c}\text { Practical } \\
\text { Applicability }\end{array}$ & $\begin{array}{c}\text { Draft Bill } \\
\text { Accepted }\end{array}$ & $\begin{array}{c}\text { Participation } \\
\text { Accepted }\end{array}$ \\
\hline $\begin{array}{c}\text { Religious } \\
\text { Compromise } \\
\text { Seeker }\end{array}$ & Yes & Partly & No & No & No & No & Yes \\
\hline $\begin{array}{c}\text { Undecided } \\
\text { Animal }\end{array}$ & Partly & Partly & Yes & Partly & Partly & Partly & Yes \\
Activist & No & Yes & Yes & Yes & Yes & Yes & No \\
\hline
\end{tabular}

On the other hand, there were the socialist party, the animal rights party, the right-wing nationalist party, the elderly party and a regional party. These Parties continued to support the bill, saw no clash with the Dutch constitution or the ECHR and believed that a practical application, providing small adjustments, would be possible. They prioritized animal welfare above religious freedom and found that participation of religious groups did not lead to the desired results (Table 4). These parties blamed their opponents of prioritizing economic benefit above animal rights. The green party entailed supporters of both sides of the debate and therefore gave their members the freedom to make an independent choice with regard to the voting.

Several factors may explain the shift of frames from the Lower House to the Upper House. First of all, the role of the Upper House as guardian of the law facilitated the adoption of a more legal frame to the issue at hand. This led to a focus on the practical applicability of the bill and its amendment, and its compliance with the Dutch constitution and the ECHR. The legal applicability of the amendment to the bill was doubted, because there was disagreement about the existence of unambiguous scientific proof and according to the conservative liberal party the criteria for the exemption were not precise enough. Conflicts of the bill with the Dutch constitution and the ECHR were recognized on several grounds. A representative of the social democratic party argued that the burden of proof had been reversed by the bill with the amendment. Due to the amendment, 
it would no longer have been the governmental responsibility to grant a constitutional right, but citizens would have to prove that they are entitled to their right. He argued that this is problematic because "freedom should be the rule and limitation should be the exception. Here the limitation is the rule and freedom the exception" (Eerste Kamer, 2011b: 12-2-2, PvdA). Another criticism was that the principles of specificity, proportionality and respect for core legal objects had not been taken into account in the drafting of the bill. "These principles demand a thorough consideration of interests, whereby the interest of protecting the constitution should weigh heavily" (Raad van State, 2008, no page). It was criticized that the bill assumes that "where fundamental ethical values are threatened, ethics needs to prevail above religion" (Eerste Kamer, 2011a). Thus, a conservative liberal representative concluded that if religious freedom is always subordinated to animal welfare, the balancing of interests disappears and ethical absolutism is the result. It has further been argued that religious freedom could not be limited on the grounds of Dutch morals since animal welfare was not considered a pressing social need by the Upper House. Furthermore, the proportionality of the problem was disputed due to the perceived larger animal welfare problems in the bio-industry. Also, the perceived use of industrial slaughter as the referential point for animal welfare was criticized in this respect. Another concern with regard to human rights was the protection of minorities in a democratic system with majority rule. The question about the representation of minorities revealed the tension between animal activists and religious minorities. In the Upper House, the hierarchy of values placed religious freedom and the related religious identity above animal rights, while trying to increase animal welfare within the frame of religious rules. Moreover, it was argued that only recently, in 2009, the Dutch animal law had been adopted which entailed the exemption for non-stunned ritual slaughter, due to possible contradiction with the constitution otherwise. Therefore, the bill was also rejected on the basis of law making history.

In addition to the legal arguments, organizational differences may have influenced the shift of frame from the Lower House to the Upper House. Due to its legal task, the Upper House is less dependent on political coalitions and therefore agreements regarding exchanges of favors and political compromises may be less important. Moreover, the Upper House cannot make adjustments to a bill to adapt it to their needs. They need to either accept or reject the bill which gives them less room for discussion on the content. This may explain why the technical inapplicability of the law led to the rejection rather than an adaptation of the amendment.

Almost all interviewees agreed that the pressure by the lobby and constituencies of the parties affected the decision-making process in the Upper House. The constituencies of the parties and their voters put political pressure on the parliamentarians to reject the bill. According to the representative of the animal rights party, the religious lobby had a very strong position in the political arena, whereas the animal activists hardly managed to reach the political parties. By some interviewees, the influence of religious organizations was framed as pressuring politicians to relent to the interests of these groups. By 
others, it was framed in terms of providing valuable information that helped the parties in balancing their decision regarding religious freedom and animal rights. Additionally, the perceived willingness of religious minorities to cooperate and improve animal welfare in their slaughter processes contributed to the frame shift. According to a representative of a Christian conservative party, a covenant is a common Dutch way of facilitating agreements between stakeholders and it is based on the idea that people signing agreement is more effective than when a law is imposed upon them. However, these kinds of agreements bring with them problems of self-monitoring, such as fraud and corruption. The public sector is needed in order to check the self-monitoring mechanism, but public interest may be subject to change. The representative of the animal rights party saw the covenant as a welcomed excuse for those political parties that were pressured by the religious lobby to diverge from the prohibition of non-stunned ritual slaughter towards a voluntary agreement. The representative of the social liberal party submitted that "the covenant could be effective as a way to force the religious groups to react to long-standing attempts of the government to cooperate and to achieve improvements, rather than enforcing a prohibition that may turn out non-compliant with the relevant treaties".

Moreover, a representative of a Christian conservative party argued that economic reasoning played a role in the shift of frame especially in the conservative liberal party. According to him, it was feared that the prohibition of ritual slaughter was just the first step on the path to improving the position of animal rights in the political sphere, which may be conveyed to the bio-industry. Such a spillover may heavily impact the Dutch agricultural export sector.

The Christian conservative parties in the Upper House especially argued that one needs to have very good reasons to limit the religious freedom of minority groups. This conservative viewpoint was used by the animal rights party as an explanation for the rejection of the bill. They argue that the Upper House is still too conservative in regard to animal welfare, but that this may change in the coming years. One of the Christian conservative parties however maintained that the Netherlands has to live up to its tradition of tolerance.

When comparing the Upper House and the Lower House debate it becomes particularly apparent that in each House there was a different dominant discourse. In the Lower House, the problem was predominantly framed in terms of animal welfare. According to one of the Christian conservative parties in the Lower House, the topic was framed so strongly towards animal suffering that one could not even speak about religious freedom. In the Upper House, the latter was weighed more heavily because the bill would have resulted in a limitation of a constitutional right. Generally, it may be said that "it was a complex debate which combined attitudes towards disputed concepts such as sciences, religion, animals, history, and identity" (Representative of a Christian conservative party). 


\section{CONCLUSION: DEALING WITH TENSIONS OF MULTICULTURALISM}

This chapter analyzed the politics of ritual slaughter in the context of the Dutch parliamentary debate about a bill intended to increase animal welfare, thereby restricting the Islamic and Jewish minority in their religious food practices. With the drafting of this bill, a practice that had previously belonged to the private sphere was transferred to the public sphere. Initially and superficially, the issue seemed to stimulate a confrontation between two sets of values: the religious values underlying non-stunned ritual slaughter versus the values of the protection of animals from what was seen as unnecessary suffering. However, on a deeper level, the issue raised the more fundamental question how a secular society should deal with multiculturalism and how much space should be given to minorities to substantiate their religious and cultural identity. The answer that was sought by political actors revealed many uncertainties and related tensions, which go far beyond the prioritization of different values. They relate to legal, political, scientific, economic and historical considerations.

In general terms, the debate touched upon the essential question in how far minorities have the right to execute their practices and to what extent the majority needs to respect those rights. In the debate, the question was posed in terms of "how much unnecessary suffering of animals is justifiable in order to assure the right to ritual slaughter?" This question is inherently normative and poses challenges to core concepts of liberal democracies. While liberal democracies grant individual rights to their citizens, rights of one individual can undermine fundamental rights of another (Sardoč, 2011) and majority views can overrule minority values, even in the presence of human rights (Zoethout, 2013). The rights-based approach requires an interpretation and a hierarchy of values. Moreover, citizens of liberal democracies may fear to lose their national identity through cultural diversity (Rietveld, 2013). This fear, even if unfounded, needs to be taken seriously by politicians.

More operational, the issue touched upon the question whether religion should play a role in the public sphere and in how far religious practices should be regulated by secular states. The separation between the church and the state is an essential characteristic of a liberal democratic society (Nadon, 2014). In the Netherlands, the state is officially impartial towards different beliefs. The 20th century idea of laïcité entailed on the one hand the separation between church and state and on the other hand the adherents' acceptance that their religion is an individual affair that belongs to the private sphere (Roy, 2007). However, in recent years, religion has returned to the public sphere, with adherents requesting acknowledgement (Roy, 2007) and what Bader calls "re-normativizing the economic and political spheres" (Bader, 2007, p.18). This raises the question whether a strict separation between state and church is necessary or even feasible. Religious minorities started to claim rights, such as the execution of religious practices in the public sphere, then requested space in institutions such as schools and the public media and finally demanded some space in the political decision-making process (Bader, 2007). 
The political actors in the debate about ritual slaughter struggled in positioning themselves amidst those fundamental questions and certainty was sought in different domains. One way was the translation of the issue in legal terms. The ECHR provides the right to freedom of thought, conscience and religion. It can only be limited in "the interests of public safety, for the protection of public order, health or morals, or for the protection of the rights and freedoms of others" (Council of Europe, 1950, no page). Article 6 of the Dutch constitution defines the right of religious freedom in the national context. Exceptions are possible "for the protection of health, in the interest of traffic and to combat or prevent disorders" (Government of The Netherlands, 2012, p.5). Whether legal obligations are seen as fixed or flexible influences the value of such provisions for the protection of minority rights. While the majority in the Lower House concluded that the adjusted bill would not be in breach with Article 6 of the Dutch constitution and Article 9 of the ECHR, the majority in the Upper House argued in reverse and additionally doubted the applicability of the bill with amendment.

The political game itself also played a role in the positions that were taken. This is displayed in several ways. First of all, there are differences in responsibilities between the Dutch Lower House and the Upper House. While the Lower House has the political task of weighing between moral considerations the Upper House is responsible for checking the legal applicability of a bill. The bill entered the parliamentary debate as an amendment to an agricultural law, which may have led the political weighing towards animal welfare, while the legal perspective in the Upper House drew more heavily on minority rights. Moreover, the Lower House is directly dependent on popular votes and coalition agreements, while the Upper House is elected by provincial representatives and is less dependent on coalition forming. Secondly, the allowance of participation by interest groups was used as a tool to strengthen frames. On the one hand, the religious as well as the animal welfare lobby provided information to the political actors, which the latter used to support their frames. On the other hand, the participation by those affected in finding a solution itself was subject to framing. While proponents of a ban on nonstunned ritual slaughter framed religious groups as unsuccessful in increasing animal welfare to the desired extent, the opponents of the ban framed religious engagement as a crucial success factor. The willingness of the religious communities to participate in a covenant to improve animal welfare may have prevented the ban. Last, bargaining power played a role as it has been argued that the Jewish organizations had more access to the political arena than Islamic and animal welfare organizations.

Another way of looking for certainty was the translation of the issue into a question of science. Scientific reports from various research institutes in different countries with diverging results were brought in by the political actors to support their frame. Yet, not only were the different conclusions regarding the effect of non-stunned ritual slaughter on animal welfare discussed, but also the validity of the data and the importance of science in policy making. Some politicians framed science as the ultimate truth and only basis for decision making with the clear aim of reducing animal suffering, while others 
framed science as diverse in itself and as one source of many on which decisions can be based.

Economic considerations also played a role. Since the Netherlands are an export country, economic considerations are important when decisions about food production are being taken. It is unknown how many animals are slaughtered without stunning, but in proportion to the industrial meat production this share is rather small. However, liberal parties may have been afraid of a spillover of animal welfare regulation towards the entire meat industry.

Except for a small fraction of the Dutch parliament that tended to seek its certainty in Islam criticism, and another small fraction that had a specific focus on animal welfare, all other parties struggled with taking position on each of these dimensions of the problem. This was further complicated by the involvement of the Jewish community. The proposed prohibition was experienced as a reminder of the Second World War as non-stunned ritual slaughter had only been abolished in the Netherlands between 1940 and 1945. Another cultural issue that became especially explicit since $9 / 11$ is the growing xenophobia in multicultural societies, especially focusing on Islam. While this factor has not been openly mentioned in the debate, some interviewees said that probably there would have been less hesitation to the prohibition if it would have only concerned Islamic food practices.

Through frame analysis, this chapter displayed how cultural diversity is expressed in the contestation of value claims regarding non-stunned ritual slaughter. The analysis shows that not one single answer is possible to the question what determines the space given to religious minorities to substantiate their identities. Although a political majority decision was taken at the end of a long trajectory, this was a compromise that leaves the controversy with its related uncertainties still open. The controversy may flare up again, also in other contexts than a parliamentary debate.

Our research focused on food-related tensions of multiculturalism in a specific context: the Dutch parliamentary debate. Future research may explore these tensions and the factors enabling space for conflicting value claims on different levels of society, for example, in the local context of multicultural neighborhoods or in the media. An analysis of related thematic issues is also suggested. Such a theme might be the governance of certification of Halal food, which also relates to a debate about public and private considerations of responsibility. Last, a comparison of the Dutch political debate with political debates in other multicultural societies is suggested to increase our insights into the relationships between multiculturalism and the politics of ritual slaughter. 


\section{REFERENCES}

BADER, V. 2007. Secularism or Democracy? Associational Governance of Religious Diversity, Amsterdam University Press.

BENFORD, R. D. 1993. "You Could Be the Hundredth Monkey": Collective Action Frames and Vocabularies of Motive within the Nuclear Disarmament Movement. The Sociological Quarterly, 34, 195-216.

BERGEAUD-BLACKLER, F. 2007. New Challenges for Islamic Ritual Slaughter: A European Perspective. Journal of Ethnic and Migration Studies, 33, 965-980.

CAMPBELL, J. L. 2002. Ideas, Politics, and Public Policy. Annual Review of Sociology, 28, 21-38.

CANTARERO, L., ESPEITX, E., LACRUZ, M. G. \& MARTíN, P. 2013. Human food preferences and cultural identity: The case of Aragon (Spain). International Journal of Psychology, 48, 881-890.

CENCI-GOGA, B. T., SECHI, P., CUCCURESE, A., POETA, A., DE ANGELIS, G., MARINI, P., MATTIACCI, C., ROSSI, R., PEZZATO, R. \& SALAMANO, G. 2013. Religious Slaughter: Data from Surveys and Spot-Check Visits in Italy and Animal Welfare Issues. Society \& Animals, 21, 459-488.

COUNCIL OF EUROPE 1950. The Convention for the Protection of Human Rights and Fundamental Freedoms. Rome.

DEWULF, A., GRAY, B., PUTNAM, L., LEWICKI, R., AARTS, N., BOUWEN, R. \& VAN WOERKUM, C. 2009. Disentangling approaches to framing in conflict and negotiation research: A meta-paradigmatic perspective. Human Relations, 62, 155-193.

EERSTE KAMER. no date. Taken en positie Eerste Kamer [Online]. Available: http://www.eerstekamer.nl/begrip/taken_en_positie_eerste_kamer [Accessed 15-08-2014].

EERSTE KAMER (UPPER HOUSE OF THE DUTCH PARLIAMENT). 2011a. Voorstel van wet van het lid Thieme tot wijziging van de Gezondheids- en welzijnswet voor dieren in verband met het invoeren van een verplichte voorafgaande bedwelming bij ritueel slachten. Memorie van antwoord. (Bill from member Thieme proposing the change of the health and welfare law concerning the introduction of mandatory pre-stunning for ritual slaughter. Statement of response). Kamerstuk 31571, nr. C.

EERSTE KAMER (UPPER HOUSE OF THE DUTCH PARLIAMENT). 2011b. Bedwelming bij ritueel slachten (Stunning for ritual slaughter). Handelingen 2011-2012, nr.12, item 2/7/9, 13 December.

EERSTE KAMER (UPPER HOUSE OF THE DUTCH PARLIAMENT). 2012. Bedwelming bij ritueel slachten (Stunning for ritual slaughter). Handelingen 2011-2012, nr.32, item 5, 12 June.

ENTMAN, R. M. 1993. Framing: Toward Clarification of a Fractured Paradigm. Journal of Communication, 43, 51-58.

FISCHLER, C. 1988. Food, self and identity. Social Science Information/sur les sciences sociales.

GOVERNMENT OF THE NETHERLANDS. 2012. The Constitution of the Kingdom of the Netherlands 2008 [Online]. Available: http://www.government.nl/documents-and-publications/regulations/2012/10/18/theconstitution-of-the-kingdom-of-the-netherlands-2008.html [Accessed 30-08-2014].

GRANDIN, T. \& REGENSTEIN, J. M. 1994. Religious slaughter and animal welfare: a discussion for meat scientists. Meat Focus International, 3, 115-123.

HAVINGA, T. 2008. Ritueel slachten: Spanning tussen religieuze tolerantie en dierenbescherming. In: BÖCKER, A., HAVINGA, T., MINDERHOUD, P., VAN DE PUT, H., DE GROOT-VAN LEEUWEN, L., DE HART, B., JETTINGHOFF, A. \& ZWAAN, K. (eds.) Migratierecht en rechtssociologie, gebundeld in Kees' studies. Nijmegen: Wolf Legal Publishers Nijmegen.

KIJLSTRA, A. \& LAMBOOIJ, B. 2008. Ritueel slachten en het welzijn van dieren. Rapport 161. Animal Science Group van Wageningen UR.

LERNER, P. \& RABELLO, A. M. 2006. The Prohibition of Ritual Slaughtering (Kosher Shechita and Halal) and Freedom of Religion of Minorities. Journal of Law and Religion, 22, 1-62.

LEVINE, H. 2011. New Zealand's ban on kosher slaughtering. Ethnology, 50, 209-222.

MINTZ, S. W. \& DU BOIS, C. M. 2002. The Anthropology of Food and Eating. Annual Review of Anthropology, 31, 99-119.

NADON, C. 2014. The Secular Basis of the Separation of Church and State: Hobbes, Locke, Montesquieu, and Tocqueville. Perspectives on Political Science, 43, 21-30.

NAKYINSIGE, K., CHE MAN, Y., AGHWAN, Z., ZULKIFLI, I., GOH, Y., ABU BAKAR, F., AL-KAHTANI, H. \& SAZILI, A. 2013. Stunning and animal welfare from Islamic and scientific perspectives. Meat Science, 95, 352361.

PRODEMOS 2012. Politiek in Nederland. Basisinformatie over democratie en bestuur.: ProDemos - Huis voor democratie en rechtsstaat. 
RAAD VAN STATE. 2008. Advies W11.08.0398/IV [Online]. Available: http://www.raadvanstate.nl/adviezen/zoeken-in-adviezen/tekst-advies.html?id=8873 [Accessed 14-08-2014].

REGENSTEIN, J., CHAUDRY, M. \& REGENSTEIN, C. 2003. The Kosher and Halal Food Laws. Comprehensive Reviews in Food Science and Food Safety, 2, 111-127.

REIN, M. \& SCHÖN, D. 1996. Frame-critical policy analysis and frame-reflective policy practice. Knowledge and Policy, 9, 85-104.

RIETVELD, E. 2013. Debating multiculturalism and national identity in Britain: Competing frames. Ethnicities, 0, $1-22$.

ROSEN, S. 2004. Physiological insights into shechita. Veterinary Record, 154, 759-765.

ROY, O. 2007. Secularism Confronts Islam, Columbia University Press.

SAlAmAno, G., CucCurese, A., POetA, A., SANTElla, E., SeCHI, P., CAMBIOTTI, V. \& CENCl-GOGA, B. T. 2013. Acceptability of Electrical Stunning and Post-Cut Stunning Among Muslim Communities: A Possible Dialogue. Society \& Animals, 21, 443-458.

SARDOČ, M. 2011. Citizenship and civic equality: tensions, problems and challenges. Annales, 21, 225-236.

SCHOLTEN, P. 2011. Constructing Dutch Immigrant Policy: Research-Policy Relations and Immigrant Integration Policy-Making in the Netherlands. The British Journal of Politics \& International Relations, 13, 75-92.

SEMETKO, H. A. \& VALKENBURG, P. M. 2000. Framing European politics: A content analysis of press and television news. Journal of Communication, 50, 93-109.

SHMUELI, D., ELLIOTT, M. \& KAUFMAN, S. 2006. Frame changes and the management of intractable conflicts. Conflict Resolution Quarterly, 24, 207-218.

SLEEGERS, F. 2007. In debat over Nederland. Veranderingen in het discours over de multiculturele samenleving en nationale identiteit. Amsterdam: Wetenschappelijke Raad voor het Regeringsbeleid.

SMITH, C. P. 2000. Content analysis and narrative analysis. In: REIS, H. T. \& JUDD, C. M. (eds.) Handbook of Research Methods in Social and Personality Psychology. Cambridge: Cambridge University Press.

SMITH, D. 2007. "Cruelty of the Worst Kind": Religious Slaughter, Xenophobia, and the German Greens. Central European History, 40, 89-115.

SNOW, D. A. \& BENFORD, R. D. 1988. Ideology, frame resonance, and participant mobilization. International social movement research, 1, 197-217.

TWEEDE KAMER (LOWER HOUSE OF THE DUTCH PARLIAMENT). 2008. Voorstel van wet van het lid Thieme tot wijziging van de Gezondheids- en welzijnswet voor dieren in verband met het invoeren van een verplichte voorafgaande bedwelming bij ritueel slachten. Voorstel van wet (Bill from member Thieme proposing the change of the health and welfare law concerning the introduction of mandatory pre-stunning for ritual slaughter. Draft law.). Kamerstuk $31571 \mathrm{nr}$. 2, 5 September.

TWEEDE KAMER (LOWER HOUSE OF THE DUTCH PARLIAMENT). 2011a. Bedwelming bij ritueel slachten (Stunning for ritual slaughter). Handelingen 2010-2011, nr.54, item 4, 17 February.

TWEEDE KAMER (LOWER HOUSE OF THE DUTCH PARLIAMENT). 2011b. Bedwelming bij ritueel slachten (Stunning for ritual slaughter). Handelingen 2010-2011, nr.73, item 2, 13 April.

TWEEDE KAMER (LOWER HOUSE OF THE DUTCH PARLIAMENT). 2011c. Bedwelming bij ritueel slachten (Stunning for ritual slaughter). Handelingen 2010-2011, nr.96, item 16, 22 June.

TWEEDE KAMER (LOWER HOUSE OF THE DUTCH PARLIAMENT). 2011d. Voorstel van wet van het lid Thieme tot wijziging van de Gezondheids- en welzijnswet voor dieren in verband met het invoeren van een verplichte voorafgaande bedwelming bij ritueel slachten. Amendment van het lid Ormel. (Bill from member Thieme proposing the change of the health and welfare law concerning the introduction of mandatory pre-stunning for ritual slaughter. Amendment of member Ormel.). Kamerstuk 31571, nr. 11, 28 June.

TWEEDE KAMER (LOWER HOUSE OF THE DUTCH PARLIAMENT). 2011e. Voorstel van wet van het lid Thieme tot wijziging van de Gezondheids- en welzijnswet voor dieren in verband met het invoeren van een verplichte voorafgaande bedwelming bij ritueel slachten. Amendment van het lid van Veldhoven. (Bill from member Thieme proposing the change of the health and welfare law concerning the introduction of mandatory pre-stunning for ritual slaughter. Amendment of member van Veldhoven.). Kamerstuk 31571, nr. 19, 28 June.

TWEEDE KAMER (LOWER HOUSE OF THE DUTCH PARLIAMENT). 2011f. Voorstel van wet van het lid Thieme tot wijziging van de Gezondheids- en welzijnswet voor dieren in verband met het invoeren van een verplichte voorafgaande bedwelming bij ritueel slachten. Stemmingen. (Bill from member Thieme 


\section{DEALING WITH TENSIONS OF MULTICULTURALISM}

proposing the change of the health and welfare law concerning the introduction of mandatory prestunning for ritual slaughter. Voting.). Handelingen 2010-2011, nr.98, item 25, 28 June.

VAN HULST, M. \& YANOW, D. 2014. From Policy "Frames" to "Framing". Theorizing a More Dynamic, Political Approach. The American Review of Public Administration, 1-21.

VAN WAARDEN, F. \& VAN DALEN, R. 2013. Halal and the Moral Construction of Quality: How Religious Norms Turn a Mass Product into a Singularity. In: BECKERT, J. \& MUSSELIN, C. (eds.) Constructing Quality: The Classification of Goods in Markets. Oxford: Oxford University Press.

VELARDE, A., RODRIGUEZ, P., DALMAU, A., FUENTES, C., LLONCH, P., VON HOLLEBEN, K., ANIL, M., LAMBOOIJ, J., PLEITER, H., YESILDERE, T. \& CENCI GOGA, B. 2014. Religious slaughter: Evaluation of current practices in selected countries. Meat Science, 96, 278-287.

VON HOLLEBEN, K., VON WENZLAWOWICZ, M., GREGORY, N., ANIL, H., VELARDE, A., RODRIGUEZ, P., CENCI GOGA, B., CATANESE, B. \& LAMBOOIJ, B. 2010. Report on good and adverse practices-Animal welfare concerns in relation to slaughter practices from the viewpoint of veterinary sciences. DIALREL.

WALLET, B. 2012. Ritueel slachten en godsdienstvrijheid in een seculiere samenleving. Religie \& Samenleving, 7, 166-183.

WELLER, D. L. \& TURKON, D. 2015. Contextualizing the Immigrant Experience: The Role of Food and Foodways in Identity Maintenance and Formation for First- and Second-generation Latinos in Ithaca, New York. Ecology of Food and Nutrition, 54, 57-73.

WOHLRAB-SAHR, M. 2004. Integrating Different Pasts, Avoiding Different Futures? Recent Conflicts about Islamic Religious Practice and Their Judicial Solutions. Time \& Society, 13, 51-70.

ZOETHOUT, C. M. 2013. Ritual Slaughter and the Freedom of Religion: Some Reflections on a Stunning Matter. Human Rights Quarterly, 35, 651-672. 


\section{Chapter}

\section{Serving a heterogeneous Muslim identity? Private governance arrangements of halal food in the Netherlands}

I don't like conflicts of interest; they should be eliminated or disclosed.

I believe in transparency: that people have to really not just know but understand what they're buying and selling.

$\sim$ Eric Schneiderman, NY Attorney General 


\section{ABSTRACT}

The consumption of halal food may be seen as an expression of the Muslim identity. Within Islam, different interpretations of halal exist and the pluralistic Muslim community requests diverse halal standards. Therefore, adaptive governance arrangements are needed in the halal food market. Globalization and industrialization have complicated the governance of halal food. A complex network of halal governors has developed from the local to the global level. In this chapter, we analyze to what extent halal certification bodies in the Netherlands address the needs of the Muslim community and how they are influenced by international halal governance. The Netherlands serves as a case study with its growing Muslim community and its central position in international trade. The data comes from literature review and eleven qualitative semi-structured interviews with the most prominent actors in the Dutch halal governance system. Our analysis shows that the halal governance system in the Netherlands is weakly institutionalized and hardly adaptive to the needs of a heterogeneous Muslim community. Improvements are needed concerning stakeholder engagement, transparency, accessibility, impartiality and efficiency.

Published as:

KURTH, L. \& GLASBERGEN, P. 2017. Serving a heterogeneous Muslim identity? Private governance arrangements of halal food in the Netherlands. Agriculture and Human Values, 34, 103-118. 


\section{INTRODUCTION}

In the last century, the food sector has developed considerably and technical innovations created a need for food standards. Governmental, intergovernmental and private institutions introduced health and safety standards. In the 1990s, a second category of sustainability standards emerged, aiming to regulate the environmental and social conditions of food production, while securing economic viability (Fuchs and Kalfagianni, 2010, Fuchs et al., 2011). These standards are based on moral considerations and non-governmental organizations (NGOs) often play a role in their initiation, whether or not in collaboration with businesses and governmental organizations. Meanwhile, these standards have created new business opportunities, particularly in niche markets, and certificates serve as marketing tools (Bitzer and Glasbergen, 2015). Research is abundant on these governance mechanisms; topics of research are for example the development of the standards (Lewandowski and Faaij, 2006, Bartley, 2003, Glasbergen, 2007), their legitimacy (Bernstein and Cashore, 2007, Hachez and Wouters, 2011, Steffek, 2009), and their effectiveness (KPMG, 2013, Blackmore et al., 2012, Quaedvlieg et al., 2014). Almost all standards that have been studied can be labelled as secular. This is remarkable, as there is a growing third category of standards which are inspired by and express a religious and cultural identity.

In multicultural societies, religiously inspired food standards assist in the creation of group boundaries (Fischler, 1988, Mintz and Du Bois, 2002) and help immigrants, which form a religious minority in the receiving countries, to reconnect with their original culture (Weller and Turkon, 2015). They are an expression of religious and cultural identity. The largest religious minority in European multicultural societies adheres to some form of Islam. In Muslim tradition, religious food standards are derived from the Quran and the Sunna (the prophet's words and practices), as well as from ljma ("a consensus of legal opinion"), and Qiyas ("reasoning by analogy") (Regenstein et al., 2003, p.111). These sources demonstrate which foods are halal (permitted) and haram (prohibited). In general, these food standards entail the prohibition of the consumption of certain animals, blood, carrion, intoxicants and the prescription of the method of slaughtering including a blessing (Regenstein et al., 2003). Yet, the lack of one central authority in Islam, the diversity in ethnical background and degree of religiosity, as well as demographics, such as age, gender and education create diverse views on halalworthiness. For example, while some Muslims consider the consumption of halal food unnecessary in a secular context, others find the strict compliance with Islamic laws of utmost importance. For some, halal compliance is a technical problem with technical solutions, while for others it is a moral issue that needs religious devotion. Issues of contestation are, for example, slaughter practices and the use of genetically modified organisms (GMOs) and alcohol.

The global halal food market is growing. While in 2013, halal food constituted 17.7 percent of global food expenditure, its share is estimated to rise to 21.2 percent by 2019 (Thomson Reuters, 2014). Industrialization and globalization have made surveillance of 
the halal production chains increasingly difficult (Havinga, 2010). Halal is a credence quality attribute, which depends on the origin, nature and production process of products and can hardly be assessed from the final product, but depends on the monitoring of the whole production chain (Bonne and Verbeke, 2008a). In the last decades, a variety of halal governance structures have been developed in different states. While some states regulate the governance of halal food through a central agency in a hierarchical way, others lack such public institutional structures. In European multicultural societies, NGOs and commercial certification businesses, so called certification bodies (CBs), develop halal standards and issue certificates. Regional organizations in Southeast Asia, Europe and the Middle East, as well as global NGOs are trying to harmonize this multiplicity of halal standards. Existing research regarding these halal governance structures has covered consumer behavior with regard to halal food (Tieman et al., 2013, Khenfer and Roux, 2012, Bonne and Verbeke, 2006, 2008b); proposals to introduce halal assurance systems (Tieman and Ghazali, 2014, Bonne and Verbeke, 2008a); governance systems and perspectives on halal in different countries (Fischer, 2008, 2015); global halal politics (BergeaudBlackler et al., 2015); and combinations thereof (Van der Spiegel et al., 2012). Some discuss how the supply side has influenced the development of the European halal food market and its diversity (Lever and Miele, 2012, Van Waarden and Van Dalen, 2013). In this chapter, we aim to bridge the gap between the information about the supply side of halal certification and the demand for halal food by consumers. Especially, in multicultural states with a heterogonous Muslim community and non-institutionalized governance arrangements it is not clear in how far the needs of the Muslim consumers are represented by CBs. Therefore, we will analyze to what extent halal CBs in the Netherlands address the needs of the Muslim community and what is the influence of the international halal governance.

The Netherlands serves as a case study due to its immigration history, its reputation as multicultural society and its central position in international trade. In the 1960s/70s the Netherlands experienced a wave of organized work migration, mainly bringing Muslims from Turkey and Morocco to the country, which now form the largest Islamic group. Later migration waves of asylum seekers brought Muslims inter alia from Afghanistan, Iraq, Iran, Somalia, and lately from Syria to the Netherlands. Multiculturalist policies gave a lot of freedom to the Islamic groups to establish their own lifestyle. Since the 2000s, voices rose in politics and the public to limit this freedom (Sleegers, 2007). At the same time, the Netherlands has an industrialized and export-oriented food sector and due to its large harbor, the country plays a major role in the trade of halal food within Europe, as well as in the Middle East and Africa (Van der Spiegel et al., 2012). Five large formal and many small informal halal CBs have developed to regulate the growing halal market. The former also facilitate the requirements for halal certificates by some export markets. Understanding the extent to which halal CBs fulfil the needs of the Dutch Muslim community and the influence of international halal governance gives insights in the govern- 
ance challenges arising from a globalized food market combined with the heterogenization of values in multicultural societies. Our framework for the assessment of the responsiveness of the Dutch halal CBs entails four elements: the correspondence of the halal standards with the heterogeneity of the Muslim community; the adaptation of the CBs to the cultural and ethnic heterogeneity of the Muslim community; the framing of the governance problem and resulting governance practices and; the strategies different CBs use to legitimize their actions towards the consumers. In the conclusion, we use the International Social and Environmental Accreditation and Labelling (ISEAL) credibility principles to evaluate how the Dutch halal CBs could improve their strategies and actions in order to create positive impact to the heterogeneous Muslim community. ISEAL gives a guideline for the essentials that lead a standard setting system to create positive impact and has been embraced by large sustainability standard setters, such as the Forest Stewardship Council and Fairtrade. It may be able to assist halal CBs in delivering positive impact to the heterogeneous Muslim community in multicultural societies.

In the following section, we explain the methodology and methods used for the analysis. Then, we elaborate on the heterogeneity of the Dutch Muslim community and its demand for halal standards. Thereafter, we give an account of the halal governance system globally, and the Dutch halal food market and its mechanisms more specifically. In the next step, we explain our theoretical framework and analyze the Dutch halal governance system regarding its adaptability to the Dutch Muslim community and the influence by the international halal governance structure. Finally, we discuss how the Dutch halal CBs could improve their adaptability to the needs of the Dutch Muslim community.

\section{METHODS}

In this chapter, we take a constructivist approach, meaning that we consider the social reality of halal food governance as constructed by the people involved. This implies that there are a range of interpretations of the nature of halal governance. Yet, within the constructivist tradition we embrace critical relativism, which entails that even though reality is socially constructed, human perception is influenced by the underlying social, political and economic structure. The methods used for our data collection come forth from this methodological approach. We executed a literature review to gain insights in the social, political and economic structure of the governance system. There is a growing interest in the topic and from the recent literature we developed a model of the governance structure. A case study approach was chosen for the analysis of the governance of a secular liberal state to ensure the feasibility of in-depth data collection from the key actors involved in the process. The insights and conclusions drawn from this case study may not be generalizable for all secular liberal states, but some general potential flaws of private halal governance systems can be identified. In order to gain insights in the experiences and interpretations of the key actors in the field of halal governance in the Netherlands, we conducted semi-structured interviews with the five largest CBs in the Netherlands, of 
whom one is also representing a meta-governor, in order to gain insights in the operations of these CBs, their development of halal standards and their stakeholder engagement. Moreover, we interviewed a former employee of the Contactorgaan Moslims en Overheid (CMO), an umbrella organization representing $84 \%$ of the Dutch mosques to the government (CMO, 2015) and an information center for halal food to understand the needs of the Dutch Muslim community and their relation to the halal CBs; one halal food producer was interviewed to gain insights into their role as connecting market force between the halal CB and the consumer. Finally, we interviewed a Turkish halal CB, whose director is representing a meta-governor and two representatives of regional governors to investigate the relationship between the Dutch halal CBs and the international halal governance initiative. ${ }^{1}$ All interviews were recorded. Nine interviews were conducted in Dutch and two in Turkish. The Turkish interviews were translated in summary to English. All interviews were deductively coded with the coding software MAX QDA to allow a structured analysis. Although the sample size of eleven semi-structured interviews is small, the data collected has been triangulated with the literature on other case studies, a policy report from a CB as well as information from the actors' websites, their standards and procedures. One of the authors also visited the first Halal Expo 2015 in Eindhoven and talked to several exhibitors as well as visitors.

\section{DIVERSITY WITHIN THE DUTCH MUSLIM COMMUNITY AND ITS HALAL CONSUMPTION}

Even though Muslims identify themselves as members of the global Ummah (the Islamic community) (Khan, 2000), when looking at studies by authors from the Middle East, instead of "unification we see internal pluralism, ethnic diversity and multiple discourses" (Manger, 1999, p.3). In the literature, we found this pluralism on three levels; religiousinstitutionally, societally and individually. Religious-institutionally, there is no single authority in Islam. Instead, it is separated in denominations, schools and sects. There are two main denominations, Shia and Sunni. Within Sunni Islam, which comprises $75 \%$ of all Muslims in the world, there are four religious schools (Van der Spiegel et al., 2012) with different interpretations of the religious texts and practices. ljma and Qiyas provide religious leaders with the tools to interpret the religious texts in a flexible way, which increases the diversity of interpretations (Van Waarden and Van Dalen, 2011). Societally, cultural, historical and political differences led to the development of diverse cultures and religious practices of Islam between and within Islamic states (Bayat, 2003). In his research regarding British Muslims, Khan (2000, p.31) found that they "reflect the linguistic, cultural and racial diversity of their origins". The same may be assumed for Muslims

\footnotetext{
${ }^{1}$ Five of these interviews were conducted by one of the authors in the framework of the production of a Dutch television documentary regarding the halal worthiness of Dutch halal products and the role of halal certification therein (Moslim Omroep, 2015). Yet, we would like to state that the result of this research is independent from the documentary and no conflict of interest exists.
} 
that migrated to other secular states. Yet, even groups with the same cultural background, such as Dutch Moroccans or Turks, internally do not have "an entirely shared and homogeneous culture" (Slootman, 2015, p.11). This may be explained by the third level on which Muslims interpret the holy texts for their daily life, individually, thereby taking interpretations from different scholars into account. Gender, age, class, ethnicity and education may play a role in the development of pluralism in the Ummah as much as in any other community (Manger, 1999).

In 2010, Muslims were estimated to constitute 6 percent of the European population and 5.5 percent of the Dutch population (Pew Research Center, 2011). Estimates from 2007 show that the majority (69\%) of all Dutch Muslims has a Turkish or Moroccan background, while other large groups come from Surinam, Afghanistan, Iraq, Somalia and there are about 12000 Muslims with Dutch origin (CBS, 2007) Due to the new migration wave towards Europe since 2014, these estimates might have changed, but no new data is available at the time of writing. The central office for statistics announced that the group of Syrians registered in Dutch municipalities has risen to 37000 in October 2015 (CBS, 2015). This overview, even if outdated shows the diversity of ethnical and cultural backgrounds of the Dutch Muslim community and allows us to make assumptions about the diversity of Islamic denominations in the Dutch Muslim community. While the majority of Turkish Muslims adheres to the Hanafi school of thought, with a considerable Safi minority constituted of the Kurdish Turks, in Morocco the majority follows the Maliki school (Ahmad, 2010). Maliepaard and Gijsberts (2012) found differences in adherence to religious practices per country of origin (see Table 1). In addition, the table reveals that many Muslims do not adhere to religious practices regularly. For example, if $42 \%$ of the Turkish survey participants visit a mosque at least once a week, it means that $58 \%$ do not. This shows the diversity with regards to religious practices within the groups.

Table 1: Religious behavior among Muslims with different origin in the Netherlands [adjusted from SCP (Sim'11; Sing'09) in Maliepaard and Gijsberts, 2012]

\begin{tabular}{lcccccc}
\hline & Turkish & Moroccan & Afghan & Iraqi & Iranian & Somali \\
\hline Visits mosque at least once a week & $42 \%$ & $44 \%$ & $13 \%$ & $10 \%$ & $5 \%$ & $36 \%$ \\
Prays five times a day & $27 \%$ & $76 \%$ & $23 \%$ & $38 \%$ & $15 \%$ & $69 \%$ \\
$\begin{array}{l}\text { Participates all days during Rama- } \\
\text { dan }\end{array}$ & $66 \%$ & $93 \%$ & $44 \%$ & $50 \%$ & $16 \%$ & $72 \%$ \\
Eats halal every day & $80 \%$ & $94 \%$ & $66 \%$ & $69 \%$ & $34 \%$ & $83 \%$ \\
Wears headscarf (women) & $48 \%$ & $64 \%$ & $21 \%$ & $38 \%$ & $13 \%$ & $80 \%$ \\
\hline
\end{tabular}

One of the practices that have been surveyed by Miliepaard and Gijsbert (2012) is the consumption of halal food. They found that especially among Turkish, Moroccan and Somali immigrants the adherence to this religious practice is strong. Especially since the legitimacy of Islam is being questioned in Western societies, the consumption of halal food has risen, as Muslims try to reinforce their identity (Lever and Miele, 2012). In research concerning halal meat consumption behavior in France, Bonne et al. (2007) found 
that Muslims are primarily guided by the importance they personally attach to halal meat. People with a stronger Muslim identity find religious norms more important and are more likely to rely on external advice, while those with a weaker Muslim identity make more egocentric choices. The fact that perceived availability of halal meat does not influence consumption behavior may suggest that the importance attached to halal consumption prevails over convenience. Whether a Muslim adheres to halal food laws is a voluntary decision and especially the second and third generations of Muslims in Europe think thoroughly about their food choices (Bonne et al., 2007). The major reason for first generation Islamic immigrants to buy halal food is "faith, health and respect for animal welfare, whereas the second generation tends to buy halal meat in order to continue a (cultural) tradition" (Bonne and Verbeke, 2006, no page). While the older generation buys its products from small ethno-shops and local butchers based on trust relationships, the younger generation is in favor of halal labelling which would simplify convenient shopping in supermarkets (Bonne and Verbeke, 2008b).

Former research has shown that there are contentious matters with regard to the definition of halal food. One controversy exists concerning which foods are halal and which ones are haram. Contentious foods are e.g. seafood, insects, alcoholic ingredients of non-alcoholic food, and GMOs. For example, debates about the acceptability of GMO take place in the realm of sciences as well as among business men and religious scholars. While many argue that no prohibition exists in Islam, others counter that genetic modification means changing God's creation which is prohibited (Atalan-Helicke, 2015). Also, ethical concerns regarding consequences of GMOs on environmental and human health have been posed and benefits have been weighed against potential harm (Isa and Man, 2014). Probably the most famous controversy revolves around the allowed stunning methods during ritual slaughter. While no single authority exists in Islam different religious rulings (fatwas) have been issued. For example, in 1977 a fatwa from Saudi Arabia allowed stunning by captive bolt and in 1978 the Al Azhar University issued a fatwa allowing stunning in countries, where it is performed. Yet, in 1995 the Al Azhar University argued that the captive bolt should not be allowed due to its effect on the animal (Anil et al., 2010). Other controversial issues in relation with ritual slaughter are the permissibility of mechanical killing, slaughter by Jewish and Christian butchers, the animal facing Mecca and recorded prayer. Also after the ritual slaughter has been performed controversies exist with regard to transportation of haram and halal meat in the same truck, eating haram food in emergency, and trust in monitoring by fellow Muslims (Anil et al., 2010, Lever and Miele, 2012, Van Waarden and Van Dalen, 2011). Attitudes towards these controversial issues may depend on religious-institutional, societal and individual criteria. Thus, it is imperative to keep the consumers informed about production processes and ingredients to enable them to consume food that suits their Muslim identity. This is done through halal governance arrangements. 


\section{MULTI-LEVEL HALAL GOVERNANCE}

With regard to halal food, we see governance efforts emerging on different levels and by a variety of actors (see Fig 1). On the local level, the halal food market consists of the Islamic butcher, the farm or slaughterhouse, and the supermarket (Ahmed, 2008, Bonne and Verbeke, 2008a, Tieman et al., 2013). Their halal worthiness is established in four possible ways: some Islamic organizations and mosques provide information about halalworthy and -unworthy practices. Many small sellers have a trust relation with their consumers through which information about halal worthiness is supplied. Some sellers monitor their own production and issue a certificate for themselves. Moreover, there are informal certifiers, such as Imams, who give out certificates to producers that they personally know and trust (Van Waarden and Van Dalen, 2011).

On the national level, formal governance efforts are taken in the form of halal standards or guidelines, certification and accreditation. Some states without a separation between state and religion designate their ministry of religion to create their own halal food standards, such as Malaysia. In 1981, the Malaysian Prime Minister Mahathir Mohamad institutionalized and regulated halal and placed the responsibility for halal certification with the government, where it has remained until the present (Fischer, 2015). The National Industrial Standardization Committee developed a standard containing "practical guidelines for the food industry on the preparation and handling of halal food (including nutrient enhancers). It aims to set the ground rules for food products or food businesses in Malaysia" (Halal Malaysia Official Portal, 2015). According to Fischer (2015, p.3) "over the past three decades, the Malaysian state has effectively certified, standardized, and bureaucratized halal production, trade and consumption. Malaysia is described as a model country in terms of complying with halal standards, and the country has strong halal activity in food processing and the export/import trade as reflected in its systematization and standardization of halal certification". Other states with a large Muslim population choose for a public-private partnership, such as Indonesia, which maintains strong ties with an NGO called Indonesian Ulama Council (MUI) which installed the Assessment Institute For Foods, Drugs And Cosmetics Indonesian Council Of Ulama (MUI LPPOM) to develop a halal certification system and halal assurance system. Between 2005 and 2011, the MUI LPPOM “issued at least 5,896 halal certificates covering up to 97,794 product items from 3,561 companies" (MUI LPPOM, 2015). Several food regulations set by the government support the MUI, for example Regulation No. 69/1999 which requires the declaration of non-halal products. If products contain pork, they need to be labeled with a picture of a pig (Van der Spiegel et al., 2012). It should be noted that the separation between NGOs and the state is not always clear in halal governance (Lever, 2015). In Europe, the controversy between animal protection and human rights legislation has led to the development of "hybrid forms of governance of ritual slaughter" (Lever and Miele, 2012, p.530). In these liberal secular states with a Judo-Christian background, govern- 
ments are reluctant to engage with halal standard stetting beyond animal welfare concerns and the human health and safety of halal food. While the local market is based on personal trust between the Islamic sales person and the consumer (Campbell et al., 2011) in a more industrial setting often private CBs are introduced that provide halal standards and a monitoring system (Bonne and Verbeke, 2008a).

Figure 1: Multi-level halal governance structure
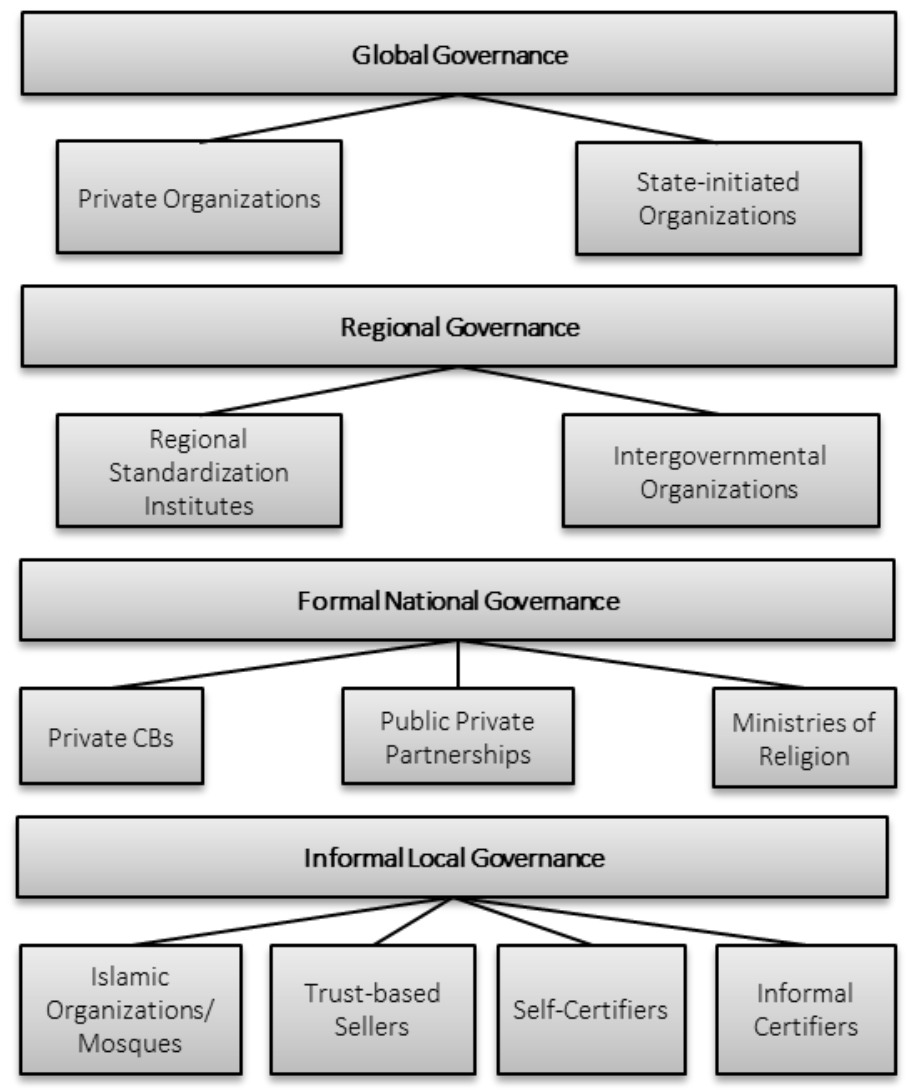

On the regional level, there are inter-governmental organizations and regional standardization institutes that are setting halal standards, such as the Association of Southeast Asian Nations (ASEAN), the Organization of Islamic Cooperation through the Standards and Metrology Institute for Islamic Countries (SMIIC) and the European Committee for Standardization (CEN). The ASEAN developed halal standards and a halal logo for its member states in 1998. The SMIIC is affiliated with the Organization of Islamic Conference and was established in 1985 in order to harmonize the standards of Islamic countries. Its statute has been signed by 23 states of which 13 have ratified it (SMIIC, 2015). In 2011, the SMIIC published its General Guidelines on Halal Food and according to one of the interviewees the development of an accreditation scheme is being pursued. In 2010, upon 
request by European Islamic organizations, the CEN formed a working group to assess the feasibility of a European norm for halal food. After completion in 2012, a CEN project committee was founded, led by the Turkish Standards Institution. The CEN cooperates with national standardization committees from 33 European countries that in turn work with businesses, religious groups and NGOs in their national context.

Overarching these three levels of governance are several meta-governance bodies. "Meta-governance involves managing the complexity, plurality, and tangled hierarchies found in prevailing modes of co-ordination" (Jessop 2003, p.108). For this purpose, the global halal meta-governance bodies are trying to create global halal standards. The most prominent ones are the World Halal Council (WHC), the World Halal Food Council (WHFC) and the International Halal Integrity Alliance (IHI Alliance). The WHFC and the WHC have a common history, as they started as one initiative in 1999 in Jakarta. In 2011, they split up and created two competing initiatives with the same objective to create global halal standards. Both work with CBs as members. According to its website, the WHC has 17 full members and 7 associated members (WHC, 2015). In 2014, the WHFC had 35 members, including well-known CBs from the United States, the Netherlands, France and New Zealand (Bergeaud-Blackler, 2015). It is also supported by the Malaysian and Indonesian halal authorities. The IHI Alliance was founded as a result of the World Halal Forum in 2006 with the goal to increase collaboration between halal authorities (IHI Alliance, 2011a). Actors on the regional and global level of governance aim at creating global halal standards to align halal production processes globally.

From this overview of the multi-level halal governance structure we can perceive the fragmentation of this market and we can assume the power play occurring between different players. Formal halal CBs in different countries are vying for international recognition by national CBs of states with a large Muslim majority or those with state power, as well as by regional or global initiatives, that connect them to global markets. Meanwhile different regional and global initiatives compete over influence on the world market and the creation of a halal hub. Hereby the question arises, which stakeholder should take responsibility for halal governance. Power differences occur between civil society, economic and state actors.

\section{DUTCH HALAL GOVERNANCE}

The World Halal Forum estimated the size of the European halal food market to encompass $\$ 66.6$ billion with the tendency to grow larger (KasehDia Sdn Bhd, 2009). A Dutch national newspaper reported that Dutch companies request thousands of halal certificates yearly and the revenues of CBs are increasing steadily (Nolles, 2015). In recent years, several scandals have given reason to doubt the halal worthiness of food. In their research using focus groups, Bergeaud-Blackler and Evans (2010) found that consumers inter alia in the Netherlands were satisfied with the supply of halal food by local butchers, while they evaluated the supply by supermarkets as average or low. While in the past, 
Muslim consumers in Europe avoided the consumption of haram food or substituted it with kosher alternatives, nowadays they request halal products equipped with a label (Bonne and Verbeke, 2008a). Especially the second-generation Muslims in Nederland is in need of halal labeling in order to guarantee the halal worthiness of products in supermarkets (Smits and Van den Berg, 2003). Tieman et al. (2013) found that 68.4 percent of Dutch halal meat consumers would be willing to pay an additional fee for the use of a halal logistic system. Companies are willing to engage with halal production either to fulfil the request of their existing customers, or in order to expand their own market. They have the option to acquire a halal certificate which may increase their reliability and is sometimes a de facto requisite for trade with other halal producers (Havinga and Gerards, 2011).

The Dutch government engages with the food market through the establishment of general laws about food production, hygiene and safety, which also apply to the production of halal food. The only aspect of halal food production that is explicitly covered by national law and extensively discussed in governmental debates is non-stunned ritual slaughter. This is mainly due to three stakeholder groups that are particularly interested in the theme: animal rights organizations, opponents of Islamization and veterinarians (Havinga, 2010). In the late 19th century, animal protection became a major concern in the Netherlands and science received growing significance, which led to the implementation of the meat inspection law in 1919. This law prescribed stunning methods for all animal slaughter with the exemption of emergency, domestic and ritual slaughter (Wallet 2012). However, the Dutch government hesitated very long before exempting the Islamic ritual slaughter from stunning, relying on the opinion of an imam from The Hague that pre-stunning of animals is not generally prohibited (Shadid and Van Koningsveld, 1992). Yet, there is no single authority in Islam that can make such a judgment for the entire Muslim community. Thus, under pressure from the Muslim community, the Dutch government finally exempted Islamic ritual slaughter from the stunning prescription in 1996 (Havinga, 2010). This decision has been contested in 2011, yet did not lead to a prohibition. Besides that, the government is reluctant to engage with halal food governance and laws regarding labeling and certification of halal food are absent. Yet, some halal logos are legally protected from unauthorized use by civil law (Havinga, 2010). This means that the logo may not be applied by a company that has not been authorized by the owner of the logo to use it. Otherwise, the government takes a liberal approach and leaves the governance of halal food to the private sector (Van Waarden and Van Dalen, 2011).

Instead, a governance system of five large private halal CBs with auditing and monitoring procedures has been established. They finance themselves through the fees paid by suppliers and retailers for their audits. They mainly serve large slaughterhouses and producers of processed food for domestic sales and export. Three of the certification bodies are authorized to certify export products (Van Waarden and Van Dalen, 2011). During our research, we found that the Dutch CBs were established in a chain reaction. The first CBs developed due to the need for export certificates because an opaque system 
of certification had progressed in the absence of governmental regulation. As the first $\mathrm{CB}$ explained, "during the inspections that we did, we realized that a certificate was needed for export. We realized that those people who gave these certificates had no idea about the technical issues. They gave certificates while the meat did not comply with the rules of ritual slaughter. We said that this is impossible".

To overcome these challenges, Halal Feed and Food Inspection Authority (HFFIA) started its activities in the 1960s with the establishment of the federation of Muslim organizations and became an official certifying agency in 1994 (Van Waarden and Van Dalen, 2011). In its policy plan, HFFIA further states that the foundation was set up by Muslims to serve the need of the Dutch Muslim community (Stichting Halal Voeding en Voedsel, 2014). The second CB, Halal Quality Control, was founded in 1983 focusing mainly on halal meat certification and in 1996 added certification of processed food. It is operated by the honorary consul of Syria to the Netherlands and is well connected internationally. The third formal CB, Halal Correct, said to have developed in order to supply meat products as its founder did not trust the second $C B$ that mainly focused on meat production. A second motivation for this CB was the possibility to earn money through certification: "Thus, instead of drawing attention to the bad practices of the other $\mathrm{CB}$, you offer alternatives. And you realize that the others are earning a lot of money and gain status. So you want that as well, and instead of joining them you start for yourself".

Halal International Control developed as a reaction to the former three, arguing that these are asking too much money for their services. The founder is a halal food producer who has the aim to make halal food available to people with a low budget. Nowadays, he produces and certifies products for major supermarkets. The youngest CB, Halal Audit Company, developed due to a perceived lack of clear communication strategies by the former CBs. It was set up by some young accountancy graduates who found that the existing CBs did not provide them with the answers that they were looking for to ensure the halal worthiness of their food. They argued that the third generation of Muslims in the Netherlands is more assertive and requests clearer communication, stating that "then our assertiveness appeared and we asked whether they could tell us how it is produced. Finally, you receive an answer, but the CBs also say 'if I say so, just accept it'”. But I wanted to understand halal. I could not receive that answer. Thus, I realized early on that there is a lack of communication".

The first three of the five $\mathrm{CBs}$ are recognized by Islamic states to issue halal certificates for export. They became members of the meta-governor WHFC, which gives them international recognition, especially when exporting to Indonesia and Malaysia. As an interviewee explained, "the WHFC is a club of internationally recognized certification bodies, or such that would like to be recognized by the Indonesian halal authority. Also, the Malaysian authority is represented there. Thus, everyone who wants to be recognized by them ends up there".

Membership in the WHFC requires a payment from the CBs and it is mainly used to ensure export rights rather than governing the domestic Muslim community. Two of 
these three CBs are also affiliated with the WHC, which is the precursor and competitor of the WHFC. The youngest Dutch certification body is a member of the IHI Alliance, an "international non-profit organization created to uphold the integrity of the halal market concept in global trade through recognition, collaboration and membership" (IHI Alliance, 2011b). All certification bodies rejected collaborating with the CEN, mainly due to its secular character: "The CEN hired imams, but will they take the final decision? It is just as if the government would say that they will develop rules for the protestant church".

In a letter from November 2011, HFFIA, Halal Correct, the CMO and a consumer organization (the Green Muslims Foundation) urged the Dutch standardization institute "to cancel the activities immediately and leave the question of the feasibility and need of a halal standard to the Muslim community" (CMO et al., 2011). There are divided opinions about the ability of the SMIIC to create a global standard. None of the certification bodies is a member, since the SMIIC consist of OIC country representatives. Yet, while some reject cooperation with the SMIIC on the basis of its economic objectives, others consider it the most fruitful initiative, due to its broad inter-governmental backing, especially if Malaysia and Indonesia would join in.

\section{THEORETICAL FRAMEWORK AND ANALYSIS OF THE DUTCH HALAL CERTIFICATION BODIES}

Halal CBs mediate between halal food providers and the Muslim consumers through establishing trust and providing information about the standards used during food production, especially with regard to controversial issues. Yet, the fragmentation of the halal market and flourishing food scandals has raised doubts about the integrity of the certification process (Atalan-Helicke, 2015). In 2010, a Dutch consumer program found that out of 10 lamb kebabs only one contained 100\% lamb meat, while one even contained pork meat (Keuringsdienst van Waarde, 2010). In 2012, a Dutch tradesman was convicted for selling South American horse meat as halal beef (Trouw, 2013). We will analyze to what extent halal CBs in the Netherlands address the need of the Muslim community and what is the influence of the international halal governance. In the literature review, we saw that controversies exist with regard to halal food and that different religious groups require diverse halal standards. Therefore, in the first step, we compare the halal standards and analyze differences and similarities. In the second step, we discuss the religious and ethnic orientation of the halal CBs to assess whether these aspects have been considered for the provision of halal food. In the third step, we look at different framings of the governance problem. Diagnostic or problem framing influences which governance approaches or solutions are considered feasible (Benford and Snow, 2000). In the context of private halal governance, the problem framing with regard to the provision of halal food influences the attitude of Muslims towards halal food as well as the governance approaches taken by CBs. The framing of the governance problem and its possible solutions can furthermore determine to what extent the Dutch CBs take the religious needs 
of the Dutch Muslim community into account as compared to export requirements and other motives. Lastly, we assess how different halal CBs try to establish legitimacy. Legitimacy refers to "a generalized perception or assumption that the actions of an entity are desirable, proper, or appropriate within some socially constructed systems of norms, values, beliefs and definitions" (Suchman 1995, p.574) and therefore "recognizing the right to govern" (Coicaud, 1997, p.10). We define legitimate governors as standard setting and enforcing entities whose standards and activities are accepted by producers, retailers and consumers (Glasbergen, 2013). Legitimacy challenges are particularly prominent in the realm of private governance as voluntary efforts need more justifications than other forms of authority. Moreover, the degree of legitimacy influences the effectiveness and efficiency of private governance and there are often no formal mechanisms for stakeholder involvement (Schouten and Glasbergen, 2011). The legitimacy of CBs has frequently been discussed concerning sustainability standards and we consider it equally important with regard to halal certification.

\section{Little differences in standards.}

Generally, it may be said that none of the CBs reinvented the wheel. While some literally took over the standards from the Department of Islamic Development Malaysia (JAKIM), others compared different existing standards, sat together with Imams and created their own standards, adapted to the European context. As a CB explained: "we compared the standards of Malaysia, Indonesia, Turkey etc. regarding their similarities and differences. We avoided all conflicting issues. We checked if this helps the halal consumers in the Netherlands and Europe and whether they accept it. Then at some point we made a summary of everything we have seen. That is our standard".

The importance of the Malaysian and other foreign standards may be explained by the use of certification mainly for the purpose of export. When CBs are recognized by foreign religious authorities their standards need to be in line with the requirements of the receiving country as a CB clarified: "We receive recognition by the countries such as Malaysia, Indonesia, UAE or Saudi Arabia. They visit us and recognize us, and we organize their certification. If we issue certificates on their behalves, this needs to happen according to their standards".

Content wise, we found that the formal standards used by the CBs are very similar. None of the standards was publicly available, but we received the standards of four CBs for our analysis. One CB said that "our standards are developed in cooperation with Imams. We have protocols to execute a screening and for the cleaning. We always have to discuss which protocols and exceptions to apply". Due to the adaptable nature of the standards, this CB did not provide us with its standards for analysis. Two of the four CBs use the Malaysian standard and therefore we only compared three standards. All standards entail a section about allowed stunning methods. While two standards prohibit the use of shooting masks, the third one specifies that only electrical or pneumatic percussive stunning is accepted. Yet, it may be concluded that all three standards provide for some 
kind of stunning. They also all require a prayer to be said wherein one does not specifically mention that the prayer has to be said by a human. Two of the three standards recommend turning the animal towards Mecca during slaughter. The third standard does not mention the issue. With regard to the use of alcohol, one standard does not give any information while one prohibits khamar, thus alcohol, and the other one allows ingredients with less than $0.05 \%$ while the final product has to be alcohol free. Two standards specify that they allow the consumption of all sea food except for those that are toxic and one also does not allow for animals that live simultaneously on land and in the water. The same standards also prohibit the use of GMO. All three standards require the separation between halal and haram food and the use of haram animal proteins as additives is prohibited by all of them.

Table 2: Comparison of anonymized halal food standards regarding contentious issues

\begin{tabular}{llll}
\hline & Standard 1 & Standard 2 & Standard 3 \\
\hline Stunning & Yes fshooting mask & Yes = electrical/pneumatic & Yes ₹shooting \\
& & percussive & mask \\
Prayer & Yes & Yes & Yes \\
Direction Mecca & Yes & Yes & Not specified \\
Alcoholic ingredients & Yes <0,05\% & No & Not specified \\
Seafood & Yes, except toxic & Yes, except toxic/living in sea & Not specified \\
& & AND land & Not specified \\
GMO & No & No & Yes \\
Separation from haram & Yes & Yes & No animal \\
Additives & No haram animal & Only from halal animals. No & proteins \\
\hline
\end{tabular}

From the overview in Table 2, we can understand that there are very small differences between the contentious issues within formal standards used by the CBs. This shows that the CBs hardly adapt to the heterogeneous Muslim community through the provision of a broad range of different standards, even though in practice some CBs find that their operations are largely based on conflicting standards. Instead, the CBs adjust to the requirements of international governors by applying standards in compliance with the Malaysian standard, which they perceive as the strictest standard on the market.

\section{Religious and ethnic orientations ignored.}

With regard to the religious orientation the Dutch CBs are very similar. They indicate that they represent the Sunni tradition of Islam. As mentioned before, the Sunni Islam is split into four schools, but the CBs claim to account for all four schools. How they do this, however, remains questionable as there are differences between the schools regarding their interpretation of halal food standards and no differentiation is visible on the halal certificates issued by the CBs. CBs in other countries differentiate between schools by making production standards explicit on their label. The ethnicity or country affiliation of the CBs may play a role with regard to the adaptability to the heterogeneous Muslim 
community for two reasons: On the one hand, Muslims with a similar ethnic background may trust each other more, and on the other hand, the country affiliation of a CB may entail that it follows the advices of the religious authority in that country. The founders of the CBs are of different ethnic decent, but several of them have a mixed team with different ethnicity. Yet, their focus on Malaysia and Indonesia as the major export market, may lead them to follow the advice of JAKIM and MUI with regard to halal food standards. Thus, neither the religious orientation nor the ethnicity and country-affiliation of the different CBs have proven to increase the adaptability of the governance to the needs of the Muslim community, as none of the CBs promote themselves as representing a certain religious affiliation or ethnic belonging. Yet, Van Waarden and Van Dalen (2011, p.23) found that CBs whose founders originated from former colonies "seemed to be more used to the western approach of relying largely on science, accountability and transparency", while founders from other countries mainly operate according to the traditions in their home country. Thus, the business operation of the CBs may be influenced by historical developments in the country of origin.

\section{Different frames of the governance problem.}

In our analysis of the eleven interviews, we found four major frames of the governance problem; economic, technical, religious and regulatory. Within the economic frame, a governance problem exists for three stakeholder groups; halal producers and retailers, halal CBs and governments. Halal producers and retailers are in need for ethno-marketing opportunities and export certificates. Halal certificates can act as marketing tools to gain the trust of the Dutch halal consumers. Moreover, in order to enter foreign Islamic markets, a halal certification is often required. The CBs may perceive the halal governance market as an unleveled playing field. They fear unfair competition from fraudulent CBs that do not comply with the same strict standards or have less stringent monitoring procedures. As a CB explained, "if every CB would collaborate with different Imams it would not be such a problem, but that is not happening. If I say that I have to pay 30 salaries every month, I must be able to earn that money as well. It is not moneymaking, but the construct in which we work". A proposed solution is the introduction of a meta-governor that enforces strict monitoring procedures. For governments, an economic problem exists in terms of import and export barriers due to the absence of one global uniform standard. Yet, the lack of uniform standards can also be perceived as an opportunity to protect domestic markets through the introduction of strict halal standards that producers from other countries can hardly comply with.

One of the regional governors in the network described the governance problem in purely technical terms: "For $99 \%$ we are talking about production standards, a technical discussion. It has nothing to do with beliefs, but with the integrity of the food production. That is what it is about, once it is halal. What is halal then? Imagine that a piece of meat is slaughtered halal, whether stunned or not, then you need to make sure that it is not contaminated by pork meat or other haram meat. That has nothing to do with beliefs, 
but it is just a production process". According to him, these technical problems should be solved by creating and enforcing technical standards that exclude the religious contentious topics. Such a frame decouples the religious nature of halal food standards from the technical production process, which makes it difficult to include the heterogeneous opinions of the Dutch Muslim community in the halal standards.

The regulatory frame focuses on the reluctance of the Dutch government to protect the term halal by creating halal standards. As an interviewee said "In the Netherlands you have laws and rules like in every other country. Halal is not registered by law. That means that someone who does not work halalworthy, but labels his products as halal, is unpunishable. But this is confusing for the consumer". Meanwhile, an information center for halal food said on its website that "there are no norms and regulations concerning the halal label, because halal is only considered a religious requirement. The lack of governmentally recognized requirements for halal certification creates skepticism towards the producers that are labeled halal" (Aaras, 2015). The underlying problem addressed here is the confusion of the Dutch halal consumer. Yet, while the CBs could have proposed governmental regulation as the desired solution most of them prefer religious groups to regulate the field through standard setting and certification.

Finally, there is the religious frame, which focuses on the consequences of eating haram meat for the individual Muslim. Securing the availability of halal food, especially in countries with a Muslim minority, is considered important to ensure their spiritual health in the current and the afterlife. Some actors argued that the responsibility for the halal worthiness of the meat lies with the producers or retailers of the food if they declare it to be halal, while others see the responsibility with the consumer to investigate whether their food was produced in a halalworthy manner. A CB explained that "in the Quran it says 'Trust your brother and sister'. Yet, it also says 'you have to be sure that your trust is good'. At the moment that you start doubting you have to stop trusting. In order to doubt or trust you have to be knowledgeable". In this frame, the religious health and identity of the Muslim consumer is the central point of concern.

Whereas the economic and the technical frame primarily focus on the simplification of export and economic gain and leave little space for adaptation to the heterogeneous Muslim community, the regulatory and the religious frame put the Muslim consumer in the foreground. Each of the halal governors employs a mix of the four frames in their motivation, but generally we can conclude that the economic frame often seems to gain primacy above the other three.

\section{Different forms of legitimacy.}

For the acceptability of standards and certificates to stakeholders we consider three aspects as important; stakeholder participation, external legitimation and transparency of certification processes. Stakeholder participation is especially important when formal democratic legitimation is absent. Private governance arrangements can be internally legitimized if stakeholders feel represented in the decision-making processes (Nanz and 
Steffek, 2004). Unlike most sustainability-related CBs, the Dutch halal CBs represent no partnerships between societal NGOs, halal producers and retailers, but they are either commercial certification businesses or NGOs aiming for certification. Standards are developed with the aid of handpicked imams and foreign religious authorities and monitoring occurs behind closed factory doors. The CBs neither accommodate the participation of halal producers and retailers, nor of the Muslim community. Independence of the CB can increase their reliability, as monitoring can be executed independently (Havinga and Gerards, 2011). However, the CBs receive fees from the halal producers and retailers for their services, which indicate their economic dependency. The non-involvement of halal producers and retailers may be required by the absolute nature of religion, which leaves little space for negotiation. As the former representative of the CMO explained with regard to CEN's initiative to create a participatory standard setting process "how are you going to negotiate with businesses about halal? What they do not understand is that you cannot negotiate on that. There is no way of negotiating with businesses about a religious principle". Yet, since different interpretations of halal exist within the Dutch Muslim community, its participation in the standard setting and monitoring process could be crucial for the legitimacy of the CBs to the Dutch consumers.

External legitimacy refers to the governance of governance or to the question of who accredits the CBs. The Dutch CBs try to gain external legitimacy in three ways; from international governance, through private mechanisms, and by religious leaders. International governance entails the endorsement by foreign governments directly, for example through the permission to certify halal products for them. Otherwise, CBs can be accredited by regional or international meta-governors, which are legitimized by governments. A respondent explained that "the countries that import halal food are especially careful. Thus, if all of them have accepted the SMIIC, why should we not trust it?" and "in the end there will be companies and governments that will say 'I trust the EU, all the others are not as professional, and thus I trust their standard'".

Private mechanisms used to create legitimacy are brand recognition and mutual acceptance of standards. A CB explained how collaboration with a trusted supermarket chain helps his publicity: "I am delivering products to the Albert Heijn (a renowned Dutch retail chain) and I am happy. In terms of publicity, it is enormous, a lot of doors open for you. With the other supermarkets you conduct business, but the Albert Heijn is an institute". Mutual recognition of certificates was considered important by a CB as he stated that "our power is that if we reject a certificate, we often receive request from companies whether we recognized a certain CB. If we say no, they already know enough. We have become a database for reliability". This view has been supported by a halal producer that we interviewed, who said that "I have chosen my halal CB, because my suppliers work with the same body. We would like to keep it in one chain, so that we can always trace back our products". Other private actors that developed to monitor the CBs are consumer organizations, such as ikeethalal.nl and the halalpolitie, which inform consumers about the practices of the CBs and the halal worthiness of products. They create, for example, 
critical internet blogs, make television programs about halal food, rate halal producers regarding their halal worthiness and have created a reporting point for halal misuse. Religious legitimacy is aspired through close cooperation with leading imams and Islamic organizations in the Netherlands and abroad. Two Dutch CBs installed their own standing boards of imams from the four Sunni schools, but also the other CBs confirmed that they consult domestic and foreign imams for ambiguous matters. An interviewee argued that "even if I know the answer for sure, if I receive a question I first present it to the imams. I need to hedge myself". Moreover, some CBs designate devout Muslims to the halal producers where they monitor the halal production processes to guarantee their halal worthiness constantly.

Transparency may create legitimacy as it makes certification processes comprehensive and enables stakeholders to choose which standards and procedures they find acceptable. We assessed the transparency of the halal CBs regarding the information published on their website and the expressiveness of the halal certificates and logos. None of the logos and certificates that we analyzed entails specifications with regard to the standards that have been applied during the production process. They refer to the fulfillment of Islamic law/guidelines or their own directives/required standards, but do not specify the meaning thereof. Thus, the consumer cannot understand from the certificate according to which standards a product has been produced. Some of the CBs' websites offer some of the standards used, but give no detailed account or copy of their official standards and procedures. The representative of the information center for halal food questions whether halal certification is "reliable if the CB cannot support his answers by the criteria he uses and the Islamic law on which they are based. Then it is up to the consumer or the company to make the decision". Yet, upon request four of the five CBs disclosed their halal standards.

\section{CONCLUSION}

The halal governance system in the Netherlands is weakly institutionalized and hardly adaptive to the needs of a heterogeneous Muslim community. The analysis shows that the weak institutionalization manifests itself in multiple ways: Firstly, there is a complex multi-level system of certification bodies with overlapping scales and fields of governance. Secondly, the CBs are financially dependent on the halal producers and retailers that they monitor and they are economically and politically dependent on international governors for export permits. Thirdly, overlapping standards are used that are mainly determined by international governors due to the size of the export market. Fourthly, ethnic and religious backgrounds are neglected, while these are important signifiers of the heterogeneity in the Dutch Muslim community. Fifthly, diverse frames of the governance problem exist, which seem to be dominated by the economic frame. Finally, the governance system is opaque with regard to standards and procedures and it lacks open participatory processes; legitimacy is sought from external actors instead. 
The system does not meet the standards that have been formulated by international organizations for credible private governance of sustainable production, such as the ISEAL Alliance. In our discussion thereof, we will specifically focus on the CBs' relevance, stakeholder engagement, transparency, accessibility, impartiality and efficiency. Considering these standards reveals where improvements are necessary to create a reliable halal governance system.

One of the ISEAL credibility principles (ISEAL Alliance, 2013) is relevance, which entails that the right problem is addressed, and that the requirements serve the objective, reflect scientific understanding, international norms and are adaptive to local needs. In order to apply this principle to halal governance the framing of the governance problem is crucial. When we speak of an economic governance problem an international harmonization of standards may be desirable, while a religious problem definition may involve a local adaptation of standards and transparency. Whether and how scientific insights with regard to sustainable food production should be integrated with halal food standards stays a topic of debate, exemplified in the diverse opinions with regard to pre-stunning and GMOs.

Another ISEAL principle is stakeholder engagement, which implies that a representative group of stakeholders should be invited during the process of standard creation and adaptation and that a complaint system should be in place. As explained before, the challenges with regard to stakeholder involvement lie in the tension between the universal truth of religion and diverse interpretations and implementations of religion in practice. Depending on the problem framing, there may be no room for negotiation with industry or other non-religious stakeholders for example. However, leverage with regards to governmental requirements and different interpretations of the Quran exist and should be used to serve the heterogeneous needs of the Muslim community. For this to happen, the transparency, accessibility and impartiality principles are imperative.

Transparency requires that relevant information about the development and content of the standards are freely available. This principle has found little application by the halal CBs so far. While some publish part of their standards on their website, others disclose no information, especially with regard to contested standards. In addition, the process of standard development is not explicitly mentioned on any of the CBs' websites, yet is disclosed upon request.

Accessibility requires that costs and unnecessary requirements are minimized and information about the standards, trainings and financial resources for capacity building be provided. The costs for the certification vary considerably between the different CBs (Havinga and Gerards, 2011). Whether requirements are considered unnecessary is again dependent on the objective of the CB. Some CBs already offer workshops for halal producers throughout the production chain.

The principle of impartiality is crucial for the stakeholders to feel represented and taken seriously. As seen in the analysis, it appears that commercial interests and the needs of the international governors are still given preference above the needs of the 
Dutch Muslim community. The governance problem is mainly economically defined, standards are developed regarding the Malaysian system, ethnic and religious differences are not emphasized and participatory processes and transparency are lacking. Generally, economic interests do not have to compromise public interests, but provision of information is needed.

Finally, the ISEAL principle of efficiency suggests that the system should become efficient and cost-effective for the consumers through cooperation between schemes, sound revenue models and organizational management strategies. In our research, we have seen that the Dutch CBs use overlapping standards and for a large part fulfil the same function of facilitating export. Their geographical scope seems to be defined by demand rather than by strategic organization and cooperation. More coordination between the CBs could lead to more resource-efficient halal governance for the domestic and the international market and would allow for a better adaptation to the needs of the heterogeneous Dutch Muslim community.

Our research contributed to the body of scholarly literature by comparing the supply side of halal governance with the demand of the heterogeneous Muslim community, unraveling the underlying dependencies between different levels of governance, uncovering the effect of different framings of the governance problems and highlighting challenges that exist with regard to religious food certification and potential solutions. Further research should take the comparison of supply and demand side a step further by gaining deeper insights in the needs of the heterogeneous Muslim community, possibly by means of in-depth interviews with respondents from different age groups, ethnic background, degree of religiosity, education level etc. Moreover, further research should consider the political impact of immigration and integration on the demand and supply of halal food and the influence of international governance structures. Finally, further research should focus on increasing reliability of the halal governance system.

\section{REFERENCES}

AARAS, M. 2015. Halal certificering in kaart [Online]. Available: http://www.ikeethalal.nl/halal-certificeringkaart/ [Accessed 06-07-2015].

AHMAD, A. U. F. 2010. Theory and practice of modern Islamic finance: the case analysis from Australia, Universal-Publishers.

AHMED, A. 2008. Marketing of halal meat in the United Kingdom: Supermarkets versus local shops. British Food Journal, 110, 655-670.

ANIL, H., Miele, M., VON HOLLEBEN, K., BERGEAUd-BLACKLER, F. \& VELARDE, A. 2010. Religious Rules and Requirements - Halal Slaughter. In: MIELE, M. \& ROEX, J. (eds.) Dialrel Reports.

ATALAN-HELICKE, N. 2015. The halal paradox: negotiating identity, religious values, and genetically engineered food in Turkey. Agriculture and Human Values, 32, 663-674.

BARTLEY, T. 2003. Certifying Forests and Factories: States, Social Movements, and the Rise of Private Regulation in the Apparel and Forest Products Fields. Politics \& Society, 31, 433-464.

BAYAT, A. 2003. The Use and Abuse of'Muslim Societies'. ISIM Newsletter, $13,1$.

BENFORD, R. D. \& SNOW, D. A. 2000. Framing processes and social movements: An overview and assessment. Annual review of sociology, 611-639. 
BERGEAUD-BLACKLER, F. 2015. Who owns halal? Five international initiatives of halal food regulations. In: BERGEAUD-BLACKLER, F., FISCHER, J. \& LEVER, J. (eds.) Halal Matters: Islam, politics and markets in global perspective. London \& New York: Routledge.

BERGEAUD-BLACKLER, F. \& EVANS, A. 2010. Halal consumer attitudes and opinion towards ritual slaughter. Dialrel Reports.

BERGEAUD-BLACKLER, F., FISCHER, J. \& LEVER, J. 2015. Halal matters: Islam, politics and markets in global perspective, Routledge.

BERNSTEIN, S. \& CASHORE, B. 2007. Can non-state global governance be legitimate? An analytical framework. Regulation \& Governance, 1, 347-371.

BITZER, V. \& GLASBERGEN, P. 2015. Business-NGO partnerships in global value chains: part of the solution or part of the problem of sustainable change? Current Opinion in Environmental Sustainability, 12, 35 40.

BLACKMORE, E., KEELEY, J., PYBURN, R., MANGUS, E., CHEN, L. \& YUHUI, Q. 2012. Pro-poor certification: Assessing the benefits of sustainability certification for small-scale farmers in Asia. In: MAYERS, J. (ed.) IIED Natural Resource Issues. London.

BONNE, K. \& VERBEKE, W. 2006. Muslim consumer's motivations towards meat consumption in Belgium: qualitative exploratory insights from means-end chain analysis. Anthropology of food.

BONNE, K. \& VERBEKE, W. 2008a. Religious values informing halal meat production and the control and delivery of halal credence quality. Agriculture and Human Values, 25, 35-47.

BONNE, K. \& VERBEKE, W. 2008b. Muslim consumer trust in halal meat status and control in Belgium. Meat science, 79, 113-123.

BONNE, K., VERMEIR, I., BERGEAUD-BLACKLER, F. \& VERBEKE, W. 2007. Determinants of halal meat consumption in France. British Food Journal, 109, 367-386.

CAMPBELL, H., MURCOTT, A. \& MACKENZIE, A. 2011. Kosher in New York City, halal in Aquitaine: challenging the relationship between neoliberalism and food auditing. Agriculture and human values, 28, 67-79.

CBS. 2007. Ruim 850 duizend islamieten in Nederland [Online]. Available: http://www.cbs.nl/nl$\mathrm{NL} / \mathrm{menu} /$ themas/bevolking/publicaties/artikelen/archief/2007/2007-2278-wm.htm [Accessed 1712-2015].

CBS. 2015. Groeiend aantal Syriërs ingeschreven bij gemeenten [Online]. Available: http://www.cbs.nl/nl$\mathrm{NL} / \mathrm{menu} /$ themas/dossiers/allochtonen/publicaties/artikelen/archief/2015/groeiend-aantalsyriers-ingeschreven-bij-gemeenten.htm [Accessed 17-12-2015].

CMO. 2015. Visie, missie en inspiratie [Online]. Available: http://cmoweb.nl/index.php/component/content/article?id=73 [Accessed 10-07-2015].

CMO, HALAL CORRECT, HVV \& GREEN MOSLIMS FOUNDATION 2011. Letter about the CEN halal standardization project.

COICAUD, J. M. 1997. Légitimité et politique. Contribution a l'étude du droit et de la responsabilité politiques. Presses Universitaires de France. English edition: COICAUD, J.M. 2002. Legitimacy and politics: a contribution to the study of political right and political responsibility (trans: David Ames Curtis). Cambridge University Press.

FISCHER, J. 2008. Feeding secularism: The halal market in London.

FISCHER, J. 2015. Malaysian diaspora strategies in a globalized Muslim market. Geoforum, 59, 169-177.

FISCHLER, C. 1988. Food, self and identity. Social science information, 27, 275-292.

FUCHS, D. \& KALFAGIANNI, A. 2010. The Causes and Consequences of Private Food Governance. Business and Politics, 12.

FUCHS, D., KALFAGIANNI, A., CLAPP, J. \& BUSCH, L. 2011. Introduction to symposium on private agrifood governance: values, shortcomings and strategies. Agriculture and Human Values, 28, 335-344.

GLASBERGEN, P. 2007. Setting the scene: the partnership paradigm in the making. In: GLASBERGEN, P., BIERMANN, F. \& MOL, A. (eds.) Partnerships, Governance and Sustainable Development: Reflections on Theory and Practice. Cheltenhem: Edward Elgar Publishing Limited.

GLASBERGEN, P. 2013. Legitimation of Certifying Partnerships in the Global Market Place. Environmental Policy and Governance.

HACHEZ, N. \& WOUTERS, J. 2011. A Glimpse at the Democratic Legitimacy of Private Standards. Assessing the Public Accountability of Global G.A.P. Journal of International Economic Law, 14, 677-710.

HALAL MALAYSIA OFFICIAL PORTAL. 2015. Malaysian Standard on Halal Food (MS 1500:2009) [Online]. Available: http://www.halal.gov.my/v4/index.php/en/garis-panduan/standard-malaysia [Accessed 09-07-2015]. 
HAVINGA, T. 2010. Regulating halal and kosher foods: different arrangements between state, industry and religious actors. Erasmus Law Review, 3, 241.

HAVINGA, T. \& GERARDS, C. 2011. Halal en koosjercertificering in Nederland. Een verkennend onderzoek naar de regulering van halal en koosjer voedsel in Nederland. In: HAVINGA, T., KULK, F. \& BÖCKER, A. (eds.) Nijmegen Sociology of Law Working Papers Series 2011/02. Nijmegen.

IHI ALLIANCE. 2011a. Background [Online]. Available: http://www.ihialliance.org/background.php [Accessed 0608-2015].

IHI ALLIANCE . 2011b. Welcome to IHI Alliance [Online]. Available: http://www.ihialliance.org/home.php [Accessed 10-07-2015].

ISA, N. M. \& MAN, S. 2014. "First Things First": Application of Islamic principles of priority in the ethical assessment of genetically modified foods. Journal of agricultural and environmental ethics, 27, 857870.

ISEAL ALLIANCE 2013. Principles for Credible and Effective Sustainability Standards Systems. ISEAL Credibility Principles.

JESSOP, B. 2003. Governance and meta-governance: on reflexivity, requisite variety and requisite irony. Governance as social and political communication, 101-116.

KASEHDIA SDN BHD 2009. World Halal Forum Europe. Post Event Report. The Hague.

KEURINGSDIENST VAN WAARDE. 2010. Döner [Online]. Available: http://keuringsdienstvanwaarde.kro.nl/seizoenen/2010/30-39057-21-01-2010 [Accessed 24-082015].

KHAN, Z. 2000. Muslim Presence in Europe: The British Dimension - Identity, Integration and Community Activism. Current Sociology, 48, 29-43.

KHENFER, J. \& ROUX, E. 2012. How does religion matter in the marketplace for minority settings? The case of Muslim consumers in France. EMAC 42nd Conference, 2012. 1-7.

KPMG 2013. Improving smallholder livelihoods: Effectiveness of certification in coffee, cocoa and cotton [Online]. Available:

http://www.sustaineo.org/tl_files/Sustaineo/Improving\%20smallholder\%20livelihoods\%20\%20Effectiveness\%20of\%20certification\%20in\%20coffee,cocoa\%20and\%20cotton_study\%20com missioned\%20by\%20SUSTAINEO.pdf. [Accessed 31-03-2016].

LEVER, J. 2015. Re-imagining Malaysia: A postliberal halal strategy? In: BERGEAUD-BLACKLER, F., FISCHER, J. \& LEVER, J. (eds.) Halal Matters: Islam, politics and markets in global perspective. London \& New York: Routledge.

LEVER, J. \& MIELE, M. 2012. The growth of halal meat markets in Europe: An exploration of the supply side theory of religion. Journal of Rural Studies, 28, 528-537.

LEWANDOWSKI, I. \& FAAIJ, A. P. 2006. Steps towards the development of a certification system for sustainable bio-energy trade. Biomass and Bioenergy, 30, 83-104.

MALIEPAARD, M. \& GIJSBERTS, M. 2012. Moslim in Nederland 2012. Sociaal en Cultureel Planbureau.

MANGER, L. O. 1999. Muslim Diversity. Local Islam in Global Contexts, Richmond, Curzon Press.

MINTZ, S. W. \& DU BOIS, C. M. 2002. The Anthropology of Food and Eating. Annual Review of Anthropology, 31, 99-119.

MOSLIM OMROEP. 2015. Hoe halal is Halal? [Online]. Available: http://www.npo.nl/mo-doc-hoe-halal-ishalal/28-06-2015/VPWON_1244711 [Accessed 10-07-2015].

MUI LPPOM. 2015. LPPOM MUI Pioneer Of Halal Standard \& Founder Of World Food Halal Council [Online]. Available: $\quad$ http://www.halalmui.org/newMUI/index.php/main/go_to_section/2/31/page/2 [Accessed 10-07-2015].

NANZ, P. \& STEFFEK, J. 2004. Global governance, participation and the public sphere. Government and Opposition, 39, 314-335.

NOLLES, J. 2015. Maak je spullen halal en je verkoopt nog meer. De Volkskrant.

PEW RESEARCH CENTER 2011. The Future of the Global Muslim Population. Projections for 2010-2030 [Online]. Available: http://www.pewforum.org/files/2011/01/FutureGlobalMuslimPopulation-WebPDFFeb10.pdf [Accessed 31-03-2016].

QUAEDVLIEG, J., GARCÍA ROCA, M. \& ROS-TONEN, M. A. 2014. Is Amazon nut certification a solution for increased smallholder empowerment in Peruvian Amazonia? Journal of Rural Studies, 33, 41-55.

REGENSTEIN, J., CHAUDRY, M. \& REGENSTEIN, C. 2003. The Kosher and Halal Food Laws. Comprehensive Reviews in Food Science and Food Safety, 2, 111-127. 
SCHOUTEN, G. \& GLASBERGEN, P. 2011. Creating legitimacy in global private governance: The case of the Roundtable on Sustainable Palm Oil. Ecological economics, 70, 1891-1899.

SHADID, W. A. \& VAN KONINGSVELD, P. 1992. Islam in Dutch Society: Current Developments and Future Prospects, Kampen, the Netherlands, Kok Pharos Publishing House.

SLEEGERS, F. 2007. In debat over Nederland. Veranderingen in het discours over de multiculturele samenleving en nationale identiteit. Amsterdam: Wetenschappelijke Raad voor het Regeringsbeleid.

SLOOTMAN, M. 2015. Substantive signifiers? Ethnic and religious identifications among second-generation immigrants in the Netherlands. Identities: Global Studies in Culture and Power, 1-19.

SMIIC. 2015. History of SMIIC [Online]. Available: http://www.smiic.org/smiic [Accessed 06-08-2015].

SMITS, M. \& VAN DEN BERG, J. 2003. Diversiteitsbeleid:(h) erkennen van meerstemmigheid. Den Haag: LEl.

STEFFEK, J. 2009. Discursive legitimation in environmental governance. Forest Policy and Economics, 11, 313318.

STICHTING HALAL VOEDING EN VOEDSEL 2014. Beleidsplan Stichting Halal Voeding en Voedsel Voor de jaren 2014 tot en met 2018.

SUCHMAN, M. C. 1995. Managing legitimacy: Strategic and institutional approaches. Academy of management review, 20, 571-610.

THOMSON REUTERS 2014. State of the Global Islamic Economy 2014-2015 Report [Online]. Available: http://www.flandersinvestmentandtrade.com/export/sites/trade/files/news/342150121095027/3 42150121095027_1.pdf. [Accessed 13-01-2016].

TIEMAN, M., GHAZALI, M. C. \& VAN DER VORST, J. 2013. Consumer perception on halal meat logistics. British Food Journal, 115, 1112-1129.

TIEMAN, M. \& GHAZALI, M. C. 2014. Halal Control Activities and Assurance Activities in Halal Food Logistics. Procedia - Social and Behavioral Sciences, 121, 44-57.

TROUW. 2013. Nederlander lijkt centrale figuur in paardenvleesschandaal [Online]. Available: http://www.trouw.nl/tr/nl/4516/Gezondheid/article/detail/3393909/2013/02/14/Nederlanderlijkt-centrale-figuur-in-paardenvleesschandaal.dhtml [Accessed 06-08-2015].

VAN DER SPIEGEL, M., VAN DER FELS-KLERX, H., STERRENBURG, P., VAN RUTH, S., SCHOLTENS-TOMA, I. \& KOK, E. 2012. Halal assurance in food supply chains: Verification of halal certificates using audits and laboratory analysis. Trends in Food Science \& Technology, 27, 109-119.

VAN WAARDEN, F. \& VAN DALEN, R. 2011. Hallmarking Halal. The Market for Halal Certificates: Competitive Private Regulation. Jerusalem Papers in Regulation \& Governance Working Paper.

VAN WAARDEN, F. \& VAN DALEN, R. 2013. Halal and the Moral Construction of Quality: How Religious Norms Turn a Mass Product into a Singularity. In: BECKERT, J. \& MUSSELIN, C. (eds.) Constructing Quality: The Classification of Goods in Markets. Oxford: Oxford University Press.

WALLET, B. 2012. Ritueel slachten en godsdienstvrijheid in een seculiere samenleving. Religie \& Samenleving, 7, 166-183.

WELLER, D. L. \& TURKON, D. 2015. Contextualizing the Immigrant Experience: The Role of Food and Foodways in Identity Maintenance and Formation for First- and Second-generation Latinos in Ithaca, New York. Ecology of Food and Nutrition, 54, 57-73.

WHC. 2015. Members [Online]. Available: http://www.worldhalalcouncil.com/members [Accessed 06-082015]. 
Chapter

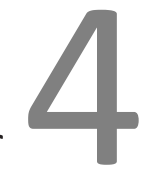

\section{The influence of populism on tolerance: A thematic content analysis of the Dutch Islam debate}

The only way to reduce the need for tolerance is

to reduce liberty or diversity or both.

$\sim \operatorname{Vogt}(1997$, p.26) 


\section{ABSTRACT}

Historically, religious tolerance has been an integral part of Dutch identity. Yet, this image has changed, particularly in the last 20 years due to the influence of populism that predominantly focused on the stigmatisation of Islam. This chapter examines how this development has changed the meaning of tolerance in the public debate about Islam and what this change means for the social and political conditions for integration in the Netherlands. An analytical framework was used, breaking down the term tolerance in five components: subject of tolerance, object of tolerance, hierarchy of values, power to interfere and limits to tolerance. The results show that while mainstream opinion leaders received more attention in public debate, populists managed to shape the tolerance discourse, changing the subjects and objects of tolerance, emphasizing contradictions between different values, shaping the hierarchy of values and proposing intolerance for Islamic intolerance as limit of tolerance.

Published as:

KURTH, L. \& GLASBERGEN, P. 2017. The influence of populism on tolerance: A thematic content analysis of the Dutch Islam debate. Culture and Religion, 18, 212-231. 


\section{INTRODUCTION}

This paper provides a thematic content analysis focusing on the question how the emergence of populism has changed the meaning of tolerance in the public debate about Islam and what this change means for the social and political conditions for Muslim integration in the Netherlands.

For centuries, tolerance has been considered an integral part of Dutch identity. Examples of such tolerance were the accommodation of Sephardic Jews during the Spanish Inquisition and of the French Huguenots (Van Genugten, 2013). In the $20^{\text {th }}$ century, tolerance for religious diversity has continued through the practice of so-called pillarization that led to a peaceful coexistence of different ideological and religious groups. This system separated Dutch society into different ideological pillars, such as Catholics, Protestants and Socialists, each with its own schools, media and social environment (Lijphart, 1979). However, secularization and de-pillarization combined with the influx of work migrants required a new approach to structure societal life. Only from 1983 onwards, an integration policy was introduced by the government (consult Vink, 2007 for more detailed information). While these policies may be perceived as multiculturalism (Sniderman and Hagendoorn, 2007), Tonkens et al. (2010) argue that group empowerment was a means for emancipation and a legacy of pillarization that was soon superseded by the aim to foster individual socio-economic participation and integration. At the latest, in the 1980/90s the image of the Netherlands as a tolerant country has changed, due to the influence of right-wing nationalist and populist movements, which since the early 2000s have predominantly focused on the stigmatisation of Islam and the so-called left-wing elites (Vossen, 2012) ${ }^{1}$.

A considerable amount of research has dealt with the emergence of populist antiIslam movements in the Netherlands (e.g. Vossen, 2010, Van Kessel, 2011, Uitermark et al. 2013, Bos and Brants, 2014, Pauwels, 2014). This research adds to the existing knowledge by focusing on the influence of anti-Islam populism on the meaning of tolerance. The results are of conceptual and societal relevance. Conceptually, this chapter offers a new operationalization of tolerance for empirical research. Societally, this research is valuable, because the relationship between Muslims and the secular majority in Europe will strongly affect the social and political cohesion of society in the following years (Van der Noll, 2014). Analyzing the changing meaning of tolerance in the public discourse can enhance our understanding of the social and political conditions (Brown, 2009) that influence the integration of Muslims in the Netherland.

\footnotetext{
${ }^{1}$ Vossen (2012) discerns three populist moments in the Netherlands: "a period between 1916 and 1918, a period between 1963 and 1967 and a period which started in 2001/2002 (28)". This article focuses on this latter period.
} 


\section{CULTURALIZATION OF POLITICS AND DE-CULTURALIZATION OF LIBERALISM}

As mentioned above, analyzing the tolerance discourse can contribute to an understanding of certain features of political and social conditions in a country. Brown (2009) specifically refers to the tension between culturalization of politics and de-culturalization of liberalism. She explains that the political discourse of tolerance is concerned with "diversity, identity, justice, and civic cohabitation (p.13)". It does not only imply withholding a reaction to a disliked action, but it enacts societal norms and practices. These norms and practices may influence identity formation and societal peace. A tolerance discourse may foster essentialism of religious and cultural differences by labelling them as objects of tolerance. By emphasizing the need for tolerance these differences become framed as undesirable. Certain subjects or objects of tolerance come to be marginalized and their position in society gets naturalized. Thereby, conflict is reduced to frictions about identities and religious and cultural differences become inherent sites of conflict. "The hegemony of culture as an over-determining explanatory frame is rooted historically in the ascent of 'race' as a political idea" (Lentin and Titley, 2012, p.132). Culturalism, much alike racism, frames culture as inevitable category that divides us from them, restricts political contestation and constrains debate to cultural differences. However, Gilroy (1991) suggests that anti-essentialism offers no cure for the division between groups either. Deconstructing racial or cultural categories while ignoring the relations of power created by essentialists may even foster racism and culturalism.

Meanwhile, liberalism is often framed as opposite to cultural identity and as neutral. According to Brown (2009) this has three reasons: Firstly, liberalism proclaims the universality of its principles instead of the particular principles of a group. These principles are the rule of law, equal rights, secularism, moral autonomy, and individual liberty. Secondly, it focuses on individual flowering rather than the advancement of the group. Finally, liberalism presumes to dominate culture and religion by relegating them to the private sphere. Yet, Brown argues that "Liberalism is not only itself a cultural form, it also is striated with nonliberal culture wherever it is institutionalized and practiced" (p.23). Young (1990) explains that the 'neutral' public sphere, supposed by liberals, favors reason beyond desires and affection. Thereby, homogeneity is forced upon the public sphere and all those who do not follow rational reason are excluded from public participation. Kundnani (2012) further elaborates that liberalism, by embracing national identity as inherently enlightened, undermines its own principle of rejecting all authority restricting free reasoning. Instead of supporting individual freedom of choice, a rejection of religion is expected from religious groups.

In recent decades, the Netherlands have seen the culturalization of politics, as well as the perceived conflict between cultural identity and liberalism. Tonkens et al. (2010) illustrate that after the 1960 s the majority of the Dutch people have developed very ho- 
mogeneously, embracing progressive values, such as gender equality, acceptance of homosexuality and new family models. This consensus on cultural values brought along the dismissal of different value systems. Several authors show that the Islamic minority has been framed in public debate as representative of a less progressive set of values (Ivanescu, 2010, Korteweg and Yurdakul, 2009, Mepschen et al., 2010). Showing tolerance towards those others is more challenging than towards those who think alike (Buruma, 2006). All of this occurred in an atmosphere of culturalization, in which cultural participation, e.g. through common values and practices became ever more important (Tonkens et al., 2010). An example of this process is the Dutch citizenship test, which normalizes secular liberalism and creates migrants as the other (De Leeuw and Van Wichelen, 2012).

\section{ANALYTICAL FRAMEWORK: THE CONCEPT OF TOLERANCE DISMANTLED}

This debate shows that the tolerance discourse is an important issue of research to understand social and political conditions. In the following, the framework of analysis shall be introduced:

In common language, the term tolerance is often associated with a positive attitude towards all kind of different people, independent of their race, religion, gender or cultural background. Similar definitions have also been used in scientific literature (Ferrar, 1976, Berggren and Elinder, 2012). However, the idea of tolerance was first applied in Western Europe in the sixteenth and seventeenth century, when struggles for power between different religions threatened to escalate. The objective was not the creation of a positive attitude towards each other, but the mutual acceptance of the existence of conflicting worldviews without violent interference. In the following centuries, the concept has been further developed: Gilson (1952/53) defines tolerance as accepting the existence of someone who holds ideas which one considers as wrong, but still giving that person the right to express these ideas freely. While Gilson focuses on ideas, Stouffer (1966) does not only measure tolerance towards the expression of ideas, but more generally with regards to civil rights one disagrees with. Vernon and LaSelva (1984) claim that tolerance only occurs if the subject of tolerance has the power to suppress the undesirable statement or behavior, but refrains from doing so. Otherwise one may not be tolerant, but helpless. In their definition, Barnum and Sullivan (1989) emphasize that an attitude of tolerance is not absolute, but a matter of degree of acceptance of disapproved ideas or behavior. Sullivan et al. (1993) apply tolerance to the realm of politics and define political tolerance as the extension of procedural rights to groups with whom one disagrees. Examples are the right to vote, participation in political parties and political persuasion (Gibson and Bingham, 1982). Vogt (1997) adds the moral and social dimension, the former relating to acts in the private sphere and the latter to people's state of being, such as their skin color or socialization. Other authors have broadly followed this general line of thought (Barnum and Sullivan, 1990, Mondak and Sanders, 2003, 2005). These definitions of tolerance may be summarized as an attitude that reflects the degree to which an actor 
with the (perceived) power to interfere accepts the existence of another individual's or group's attributes, attitudes, beliefs or behavior in the political, moral and social sphere while actually opposing them. Drawn from toleration literature, this definition may be conceptualized as an attitude that reflects the objection to a certain object of toleration by a subject of tolerance with the perceived power to interfere; and the voluntary decision of non-interference (Murphy, 1997, Garzón Valdés, 1997, Gray, 2000, Cohen, 2004, Ceva and Zuolo, 2013, Ferretti and Lægaard, 2013, Galeotti, 2015). From this conceptualization, an analytical framework has been developed to identify different ways in which a shift of the meaning of tolerance can take place (Figure 1).

The subject and object of tolerance and the power to interfere are directly derived from the conceptualization. The hierarchy of value is derived from the idea that an objection occurs as well as the voluntary decision not to interfere. Both are based on values, whereby the objection is valued less than the voluntary decision not to interfere. The last aspect of limits of tolerance is included in the framework as it appeared to be an important element of tolerance from the data analysis. Below follows a description of each aspect of the framework.

Figure 1: Analytical framework for the analysis of shifting meaning of tolerance

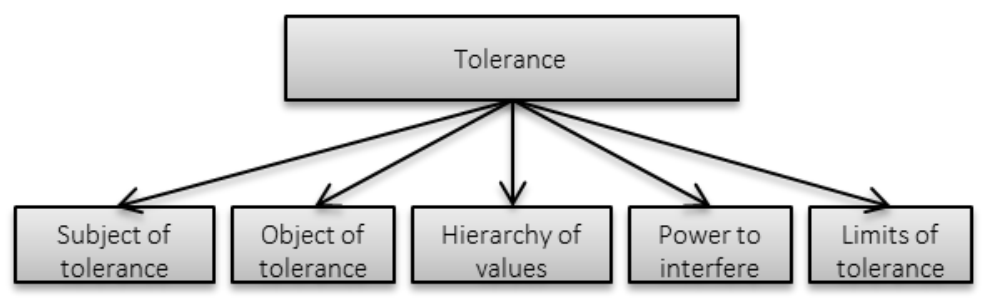

The subject of tolerance is the actor who tolerates an attribute, attitude, belief or behavior perceived as undesirable. Due to the condition that tolerance can only exists when the subject of tolerance has the power to interfere, it may be inferred that the subject of tolerance has to be part of the dominant group in society or the state. Yet, a subject of tolerance can also be part of a minority group in relation to other minorities or the powerless in the own community (Nehushtan, 2007). Moreover, being part of a minority does not necessarily imply lack of power. Thus, tolerance can either occur unilaterally or mutually.

The object of tolerance is the undesired attributes, attitudes, beliefs or behaviors of individuals or groups. What is considered an object of tolerance depends on the subject of tolerance, as all those characteristics of a group or individual that are considered undesirable may be objects of tolerance. Desirability is, however, a very subjective judgement, dependent on societal expectations and personal preferences. Moreover, relative objection may also exist, which implies that one would have preferred another option in 
the light of alternatives (Newman, 1978). Like the subject of tolerance, the object can be a feature of the majority or the minority.

The hierarchy of values occurs from the fact that tolerance is not a neutral concept, but value-laden and subject to judgement (Nehushtan, 2007). One may oppose an object of tolerance for moral reasons, out of fear etc. In order to tolerate the less desired option, there must be another value that scores higher in the hierarchy of values. An example may be the Islamic and Jewish practices of non-stunned ritual slaughter, which may be opposed for reasons of animal welfare, but accepted to ensure religious freedom (see Figure 2). However, tolerance for ritual slaughter may only occur if the value of religious freedom is considered relatively higher in the hierarchy of values than animal welfare.

Figure 2: An example for a hierarchy of values

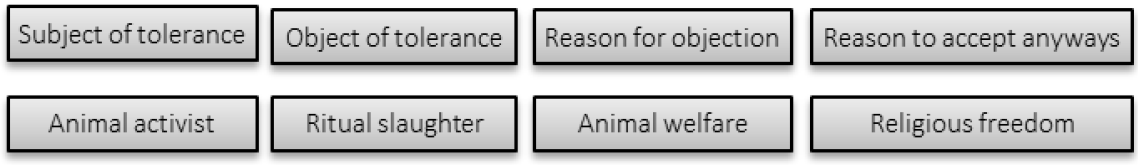

The perceived power to interfere is an inherent condition for tolerance. If the subject of tolerance lacks the perceived power to challenge the existence of the object of tolerance, we talk about helplessness, not tolerance. The perceived power to interfere may depend on whether the subject of tolerance belongs to the dominant group in society or a minority, the power dynamics between different groups, and the ability to influence the dominant discourse which reproduces or challenges power relations.

The last aspect deals with the limits of tolerance. Vogt (1997) argues that tolerance emerges in the grey realm between the immoral and the illegal. Thus, one clearly delineated limit to tolerance is defined by law, as illegal actions are not tolerated. However, there are certain attributes, attitudes, beliefs and practices that (a part of) society may consider immoral, but which are not prohibited by law. One question that often occurs in this context is to which degree society should be tolerant towards individuals or groups that are themselves intolerant.

\section{METHODS}

For this chapter, a thematic content analysis (TCA) was used in order to analyze how the framing of tolerance in relation to Islam in Dutch newspapers has influenced its meaning. While newspapers may be seen as an outdated means of public debate, they are also an especially interesting media, because they receive criticism from two sides: The populists claim that they represent a left-wing elite and at the same time they are criticized for giving too much attention to populists, due to their need for sensations.

The focus of analysis was not on the entire Islam/integration debate in the Netherlands, but on those aspects explicitly relating to tolerance. The aim was to find those themes which have reproduced or transformed the meaning of tolerance. For the TCA, 
an inductive or a deductive approach can be used. The former requires and open mind set to discover patterns in the data, while the latter involves a pre-set analytical framework and predefined themes that are sought in the data (Semetko and Valkenburg, 2000). In this research, a mixed approach has been applied with a pre-existing analytical framework described above and the openness for themes that may occur in the data.

Practically, this research entailed four steps: data collection, data sorting, data coding and data analysis. For the data collection, the Lexis Nexis search engine for Dutch newspaper articles was used with the following search strings: (Islam AND tolerant*) OR (Islam AND tolerantie) OR (Islam AND tolereren) OR (Islam AND getolereerd*) OR (Moslim AND tolerant*) OR (Moslim AND tolerantie) OR (Moslim AND tolereren) OR (Moslim AND getolereerd*). Data has been collected from November 2004, when Theo van Gogh was murdered and news coverage on tolerance and Islam peaked, until December 2015 (see Figure 3).

Figure 3: Number of articles analyzed over time

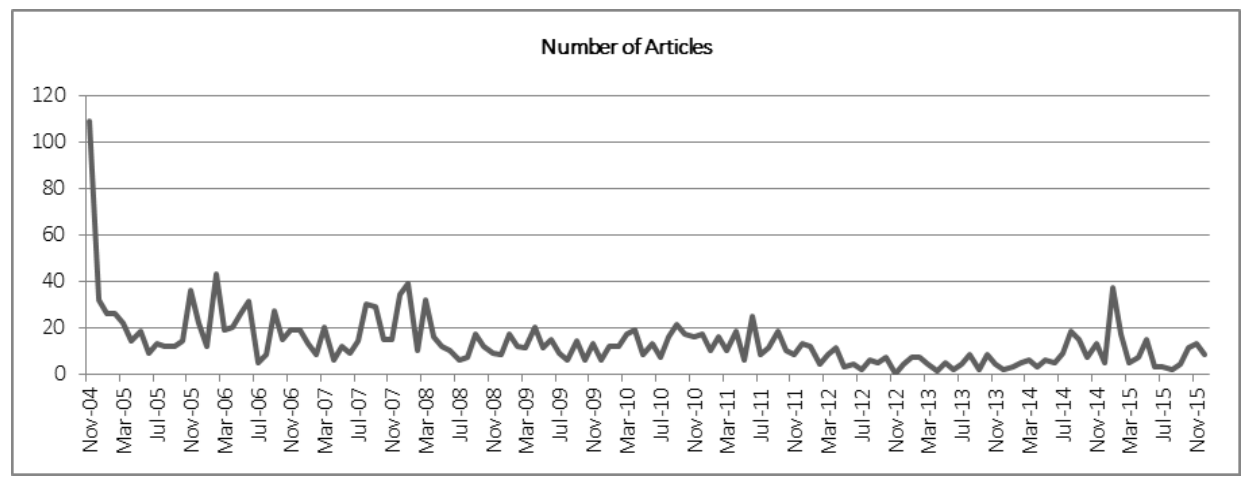

As data sources four large Dutch newspapers were chosen, representing center right (NRC), center left (Volkskrant), religious (Trouw) and a tabloid (Telegraaf). These newspapers have an outreach of respectively 215.037 (NRC), 298.065 (Volkskrant), 122.407 (Trouw), 671.860 (Telegraaf), which together constitutes almost $65 \%$ of all national newspapers, as mentioned on the website of NDP Nieuwsmedia in 2013. These data sources were selected to capture the whole spectrum of available views, rather than to compare different newspaper. In the data sorting phase, those articles that are relevant for the national debate were selected and all those articles that concerned tolerance and Islam elsewhere were excluded. The result was a total of 1800 articles that were deductively coded using the coding software MAX QDA, which makes structural analysis possible. Finally, the coded fragments were analyzed using the analytical framework. Titles of those articles directly quoted in this chapter can be found in the appendix. Shortcomings of this methodological approach are that Dutch news about tolerance and Islam in other countries and international news that may have influenced the Dutch public debate were not included unless strictly related to the Netherlands. Moreover, television and social media 
were left out, while they play an important role in today's public opinion forming. Yet, newspapers still capture the most prominent trends in public debate.

\section{EMERGENCE OF POPULISM IN THE NETHERLANDS}

In order to understand the results of the TCA, it is useful to give a definition of populism and a short overview of the events that have led to the rise of populism in the Netherlands (see Figure 4).

While there are many definitions of populism, this chapter uses Albertazzi and McDonnell (2008)'s definition of "an ideology which pits a virtuous and homogeneous people against a set of elites and dangerous 'others' who are together depicted as depriving (or attempting to deprive) the sovereign people of their rights, values, prosperity, identity and voice" (p.3). As Albertazzi and McDonnell (2008) further elaborate, populists promise a return to the heartland, which has been disturbed by the enemies of the people, if the people raise their voice by supporting populism. They create a sense of urgency and offer salvation by a charismatic leader who understands the needs of the people. Who belongs to the people and to the others can be delineated along the lines of race, class, national identity or a mix thereof. In Western Europe, the main others tend to be immigrants that are said to endanger national culture and cause social and economic problems (Albertazzi and McDonnell, 2008).

In the Netherlands, the emergence of right-wing nationalist movements started in the 1980s/90s, first led by a small party called Center Party, which requested a preferential treatment for Dutch nationals (as mentioned on the website of anderetijden.nl on 23 April 2009) and later by the liberal-conservative politician Frits Bolkestein, who emphasized the superiority of European culture over Islam (as mentioned on the website of trouw on 14 November 1997). These critics were followed by Fortuyn, who framed Islam as a backwards culture and threat to Dutch norms and values (Fortuyn, 1997). In the 2002 election, he became the frontrunner of the party, Livable Netherlands, yet, he was killed in May of the same year by an animal activist. Meanwhile, Paul Scheffer published his famous article The multicultural drama in the NRC Handelsblad on 29 January 2000, in which he drew attention to the creation of a new lower class, consisting of unintegrated immigrants. Furthermore, he warned against conservative forms of Islam that may not support the separation between state and church. Instead, he called for a revisit of Dutch values and history to prevent a loss of identity.

The events of 9/11 in New York, certainly also contributed to the shift in thinking about the Islam in the Netherlands. In 2004, Ayaan Hirsi Ali, a former Somalian refugee, ex-Muslim and Dutch politician, together with Theo van Gogh, broadcasted an Islam-critical movie called Submission, in which violent Quran texts were written over a naked female body. In November 2004, Van Gogh was murdered by a Muslim of Moroccan decent, Mohammad B. who left a threat letter for Hirsi Ali. This murder led to a fierce debate about tolerance and freedom of speech. International news about the $7 / 7$ attacks on the 
London underground and bus network and the publication of Muhammad cartoons in a Danish newspaper followed by fierce protests in the Islamic world influenced the Islam debate in 2005. In 2006, after conflicts in the parliament about her naturalization process, Hirsi Ali left the country for the US. In the meanwhile, Rita Verdonk and Geert Wilders filled the political vacuum on the populist right. As minister of integration (2003-2006), Verdonk implemented stricter integration policies, such as the civic integration course. Wilders established his Party for Freedom (PVV) in 2006 and has since become an established part of Dutch politics and receives a considerate amount of media attention, e.g. for his manifests against Islam and the movie Fitna. In 2011/12, parliamentary debates took place concerning the Islamic practices of non-stunned ritual slaughter and a ban of burkas. Since 2014, there is a seemingly ongoing series of terror attacks in Western Europe involving the terror organization Islamic State, which has steered the Dutch debate about tolerance and Islam.

Figure 1: Events influencing the development of anti-Islam populism in the Netherlands

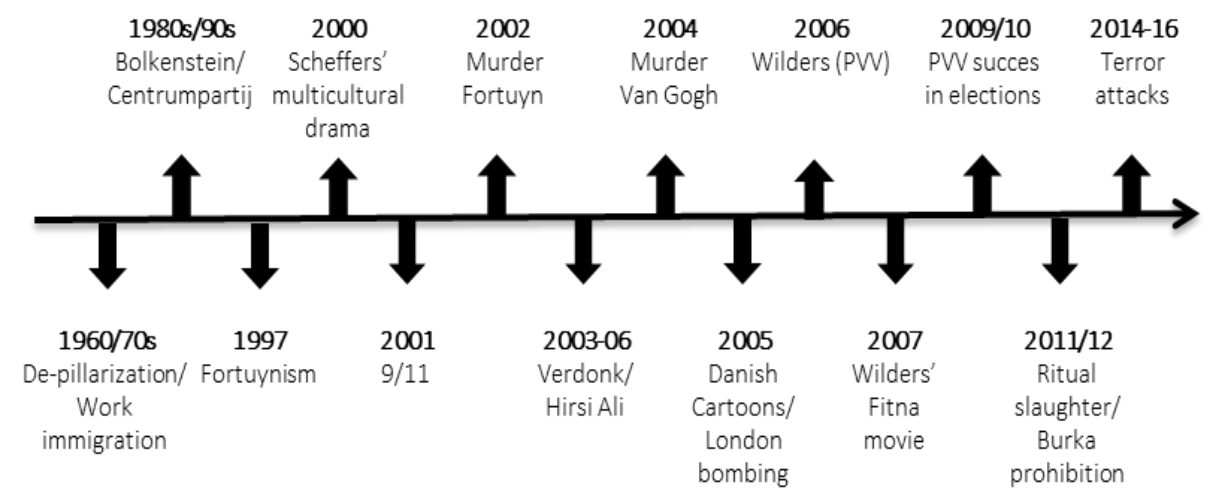

\section{SHIFTING MEANING OF DUTCH TOLERANCE}

The majority of newspaper articles analyzed are written by mainstream opinion leaders and politicians, rather than by populists. Yet, they assume populists' agendas by reproducing their message and using their terminology, even when criticizing them. To give an account of how the discourse has developed over the years, developments are analyzed in a historical manner throughout the five aspects of the analytical framework. The quotes used do not represent one single view, but are exemplary for a cluster of views expressed in news articles.

Subject of tolerance.

With regard to the subject of tolerance, it can be observed that the discourse rather focused on subjects of intolerance. Four subjects of intolerance appeared prominent in the newspaper coverage: populists, Muslims, so-called left-wing elites and secularists. 
Populists. Reactionary attacks on Dutch mosques and Islamic schools after the murder of Van Gogh in 2004 led to the accusation that populists are intolerant subjects: "Not tolerance and soft respect for immigrant cultures has led to murder, arson and extremism, but rather the slow spread of intolerance and hatred between people" (Volkskrant, 12-11-2004). Later, Wilders' success in the European election in 2009, followed by successes in national and local elections, led to an international reputation of Dutch intolerance, which fostered the idea of populists as intolerant subjects: "Thanks to the deeprooted tradition of tolerance and respect for diversity until now ethnic and religious minorities could take their rightful place. [...] These important attributes are threatened by populist preachers of fear and hatred" (Volkskrant, 20-03-2010).

Muslims. The framing of Muslims as intolerant subjects became for example apparent when in 2005, the minister of integration, Rita Verdonk, requested tolerance for Dutch values from an Imam who refused to shake her hand. In the following debate, the term political Islam was used to frame Muslims as adherents to an intolerant ideology and the term pure Islam suggested that only orthodoxy may be considered true Islam. Especially among historians and Islamic scholars, a discussion emerged whether a tolerant form of Islam exists. After the 2005 7/7 London bombings, and later Islam-related terror attacks, it was questioned whether all Dutch Muslims condemn such acts of terror. Populists framed Islam as the essential (most dominant among competing identities) and universally (only one interpretation) intolerant identity of Muslims. This framing was further reinforced using the negative reactions of Muslims after the publication of the Danish Muhammad cartoons: "If there's one thing that the Danish cartoon affair about the Prophet Muhammad has already shown it is that Islam - universal, monolithic and unfortunately intolerant - exists. The threats or the call for punishment against cartoonists, journalists and a member of the European Union are not only attributable to the orthodox and radical. The anger, which manifests itself through anathema, threats, flag burnings and boycotts, is broadly supported by the entire Islamic world" (Trouw, 02-02-2006). Throughout 2007, the populist discourse was supplemented by another idea, the differentiation between Muslims that are part of Dutch society and Islam, which is not a part of Dutch Judo-Christian tradition. This idea created the ground for requesting an assimilation of Muslims: "Despite all the problems that multiculturalism has created in recent years, the majority of the Dutch people are still tolerant, willing to adopt dissents in our country. But a good integration will only be achieved if Muslims want to take into account our Judeo-Christian traditions, and not if Islam is pushed through" (Telegraaf, 16-072007).

So-called left-wing elites. After the murder of van Gogh, the ruling parties, framed as left-wing elites by populists, were accused of applying cultural relativism, which was identified as the cause of too much tolerance. Also, after the terrorist attacks in 2014/15, leftwing policies were blamed for this development: "Voters are very doubtful, if our government does enough to identify this type of potential terrorists. They often blame our governors that they have been too tolerant over the years" (Telegraaf, 23-09-2014). 
Secularists. Those who reject all religion in the public sphere were framed as intolerant subjects: "Conservative Christians and Muslims in the Netherlands meet in their growing opposition to the attitude of secular intellectuals, who at most tolerate religion, but have no respect for it at all" (NRC, 16-03-2006). Conservative Christians criticized that "the majority culture that has developed in the Netherlands - a white, progressive, secular majority - is dictating minorities what to think and how to behave" (Trouw, 12-042010).

Besides the four subjects of intolerance, initiatives were discovered that tried to reconcile all subjects of tolerance. In 2008, a newspaper call was launched "to break with the spiral of intolerance and indifference" (NRC, 02-01-2008). It argued that "for that we need everyone, foreigners and natives; Christians, Muslims, Jews and humanists; employees and employers; politicians and citizens" (Trouw, 02-01-2008). Also with the new migration wave of Islamic refugees in 2015, it was argued that a return to more tolerance for dissidents is needed. In relation between the different subjects of intolerance, a growing tendency to ask tolerance from others, without granting them the same freedoms was observed.

\section{Object of tolerance.}

With regard to the object of tolerance we see two parallel developments: First, religious minorities were framed as objects of tolerance, starting with Muslims, but later including all kinds of religious groups. These objects of tolerance were used to frame populist and secularists as subjects of intolerance. After the publication of the Danish Muhammad cartoons in 2005, complaints arose that there is tolerance with regard to other objects of tolerance, which is absent with regard to Islam: "No major newspaper would print cartoons, mocking the blind, dwarfs, gypsies or homosexuals, not so much for fear of legal prosecution but fearing to be accused of bad taste" (NRC, 10-02-2006). Muslims and other religious minorities remarked that they increasingly became objects of intolerance. In 2012, the debate became more principled about the increased restriction of freedom for religious minorities: "However, the restriction of religious freedoms is a problem for the whole society. This restriction creates a climate in which the majority is less and less tolerant towards a deviant minority. The majority of today is insufficiently aware that they may be a minority of tomorrow" (Volkskrant, 08-09-2012).

In addition, initiatives were taken to empower disadvantaged Muslims, which reinforced the image of Muslims as objects of tolerance. For example, in 2006, several politicians signed a manifest for more tolerance towards new Dutch, a term introduced by the counter-populist discourse to replace the term allochtoon ${ }^{2}$ and to include immigrants, among which Muslims, in the Dutch identity. To address fear of the unknown, calls for

\footnotetext{
2 The term 'allochtoon' is used in policy language to describe someone who himself or whose parents were not born in the Netherlands. Among others, Van der Haar and Yanow (2011) argue that the use of this term has an excluding effect which contradicts with the aim of integration.
} 
inclusion emerge: "We have to redefine the concept of tolerance: from indifference to acceptance" (NRC, 15-09-2007).

Second, Dutch vulnerable groups in society were framed as objects of tolerance, starting with homosexuals and later also including women, apostates and like in the former case, the Jewish community. These objects of tolerance were used by populists to frame Muslims and the so-called left-wing elites as subjects of intolerance. In the beginning of 2005, a commission of the People's Party for Freedom and Democracy (VVD) framed women, homosexuals and Jews as object of tolerance and depicted Islam as essentially a backwards religion and Muslims as intolerant subjects: "According to the commission, respect for religious beliefs leads to ever more tensions, since religious Islam, which has differing views on values such as equality between men and women, homosexuality, religious tolerance and the separation of church and state, has established in the Netherlands" (Trouw, 28-02-2005).

Every year around August, when the gay parade in Amsterdam took place, homosexuals were reproduced as objects of tolerance. Yet, some homosexuals themselves refused to be used by populists to polarize between the enlightened West and intolerant Islam. In March and August 2007, a debate arose about apostate Muslims that did not feel tolerated by fellow Muslims. The populist discourse added them to the existing objects of tolerance. From 2008, populists seemed to focus even more on the failure of those, whom they label as leftwing elites, to protect groups from intolerance, whether these were homosexual, women or populists like Hirsi Ali and Wilders themselves. In December 2010, an anti-Semitism debate flared up, during which Jews, but also the other vulnerable groups were further reproduced as objects of tolerance and Islam was further framed as intolerant subjects.

Hierarchy of values.

With regard to the hierarchy of values, it can be seen that individual emancipation and religious tolerance got framed as contradicting values. This was reflected in a proposal by the liberal parties to remove the blasphemy prohibition from the Dutch constitution in 2005 and the decision by the VVD to place individual emancipation above tolerance for minorities. This conflict was further emphasized in a fight between two members of the VVD about whether special religious schools should still be permitted. This contradiction was further strengthened by linking individual emancipation to freedom of speech, and religious tolerance to freedom of religion. Views on the issue were disunited: After the Danish Muhammad cartoons, the VVD argued that freedom of speech should not be limited by the degree of resilience of Muslims against insults. Regarding the movie Fitna, populists framed Muslims as ignorant to freedom of speech and therefore intolerant towards criticism of their religion: "Muslims need to learn to deal with insults. Politicians are insulted every day. We live in a tolerant country" (NRC, 10-03-2008). Increasingly, populists framed tolerance as an absolute freedom of speech for themselves, while they advocated expelling hate-preaching Imams from the country. In June 2011, Wilders was 
acquitted from a court case for hate speech, which was seen as a gain of tolerance for free speech. In 2013, tolerance was criticized as disastrous for freedom of speech: "The new style of tolerance has a reverse effect. It is disastrous for freedom of speech. The emphasis shifts from the person who hears an unwelcome opinion to the one who expresses it" (Trouw, 26-10-2013).

The idea of a basic set of values that needs to be tolerated by everybody, but especially Muslims, in society became more explicit. After the terror attack on Charlie Hebdo in 2015, the Dutch news coverage seemed to exalt the newspaper to a symbol of free speech and condemned the attack as intolerant: "We are all Charlie Hebdo, the satirical magazine that lost its most important employees on Wednesday in an act of terror by Islamic extremists. 'This is an attack on all of us' also said Labour leader Diederik Samsom, 'on our European values of freedom and tolerance'”' (Volkskrant, 08-01-2015).

In opposition, after the Danish Muhammad cartoons, Minister Van Ardenne (Christian conservative) claimed that freedom of speech does not entail the right to insult. During the preparation for the release of the movie Fitna, mainstream politicians and opinion leaders warned Wilders not to provoke Muslims and at the same time asked Muslims to respect freedom of speech. Those supporting religious tolerance felt that their freedom of speech was restricted by populists that demonized religious tolerance. A moderate group in society asked for active tolerance, which allows for Islam critics, but does not lead to blind insult. "Bos [Labor Party] plead for active tolerance, wherein Islam receives a rightful place in Dutch society, but at the same time acquired freedoms are protected" (Telegraaf, 15-06-2008).

It shows that politicians in public debate seem to struggle with the balance between tolerances for free speech by populists and Islamic fundamentalists. The same tension also revealed itself in other debates. For example, while most actors saw the separation between state and religion as an important achievement of enlightenment, others argued that fundamental secularism may not be the solution for religious intolerance and extremism. The debate about the prohibition of non-stunned ritual slaughter in 2011/12 uncovered the tension between religious freedom and animal welfare and the debate about the prohibition of the burka in September 2011 was used to depict the tension between gender equality and religious freedom.

At the same time as these tensions were uncovered, populists framed certain values as Dutch values, while others were framed as Islamic values. This required an essentialization and universalization of both identities and at the same time these two identities were framed as incompatible: "Reading Van Doorn [a Dutch sociologist], I would like to know whether he sees no difference between people of different cultures and religions that are integrated in the Netherlands, and Muslims who demand tolerance for their religion, while they do not grant the same to other" (Trouw, 23-08-2007).

Individual emancipation, freedom of speech, separation between state and religion, animal welfare and gender equality were framed as essential and universal Dutch values, 
while religious orthodoxy, intolerance for insult, political religion, neglect of animal welfare and oppression of women were framed as essential and universal Islamic values. Others demanded a balance between critics of Islam and rights for religious minorities: "Verdonk says the same. 'After the thesis and the antithesis we get to the synthesis. The tolerance of the past was pure indifference. Now we talk to one another. Carefully, but still'" (NRC, 22-01-2007). This view is demonstrated by the alleged compromises made with regard to Islamic practices in the public sphere, e.g. the approval of headscarves, but not burkas; and a covenant between a mosque management and the surrounding citizens.

\section{Power to interfere.}

Regarding the power to interfere, we have seen that mainstream opinion leaders received more space than populists to convey their message. Yet, after the murder of Theo van Gogh, the dominant discourse struggled with Dutch identity and the meaning of tolerance: "Because the positive image of the Netherlands is crumbling. [...] The Netherlands is not famous anymore for its culture of dialogue and tolerance towards all nationalities and religions. The Netherlands is the country of political killings and burning Islamic schools" (Trouw, 21-05-2005).

Meanwhile, the populist discourse of too much tolerance for Islam filled the vacuum and became stronger. Past tolerance got labelled as indifference, relativism, and the taboo of Islam criticism, and current tolerance as cowardice. Populists pretended to represent the people and focused on Muslims to frame them as subject of intolerance and other vulnerable groups, such as homosexuals, women and Jews, as object of tolerance.

The populist discourse was reproduced by mainstream opinion leaders, who accepted the agenda set by populists and took over certain terminology of the new discourse. They argued that political Islam and terrorism should be contested, but religious Muslims should be tolerated. They clung onto the old idea of tolerance towards all kinds of minorities, but called for constructive dialogue about differences called active tolerance. They uncover the strategy of populists, like Wilders and Spruyt, but went along with the new tolerance discourse: "But it is absurd, three years after the Fortuyn revolt, to claim that the Netherlands is still in the grip of political correctness, of a sorry-culture regarding the multicultural drama, of the leftist cultural relativism, and of a fatal underestimation of the danger of political Islam. A broadloom coalition now agitates against noncommittal tolerance and no one except the Arab European League (AEL) still recommends pillarized integration or the conservation of own culture and identity" (Volkskrant, 22-03-2005).

The struggle about Dutch identity continued in mainstream articles, throughout the commotions about the Danish Muhammad cartoons until the European election in 2009, in which Wilders' PVV received almost $17 \%$ of the Dutch votes, which casted even more doubt about Dutch tolerance. Populism became personified in the figure of Geert Wilders and when his party was included in the governmental coalition, some considered this decision as tolerant and democratic, but others feared that Wilders' power would even 
increase intolerance towards Islam. Even though in 2012/13 less articles regarding tolerance in the Islam debate can be found, a polarization took place. Populists showed little understanding for religious tolerance towards Islam, framed Islam as intolerant and demanded no tolerance for intolerant. In contrast, the mainstream requested dialogue between different groups in society and focused on positive actions for tolerance. Also, Muslims were made more responsible for contributing to a tolerant society.

\section{Limits to tolerance.}

All previously discussed aspects of tolerance influenced how the limits of tolerance were defined. Populists, who created an image of Islam as a universal and essential identity that constitutes a subject of intolerance towards vulnerable objects of tolerance, used enlightenment and the argument by Karl Popper that one should not be tolerant to the intolerant to further stigmatize Islam: "Long time ago, Karl Popper taught us that you should never be tolerant of the intolerant, but spiritless Europe forgot this lesson and seems to bow to the terror of the street out of cultural self-hatred; Europe is (again) too naive to recognize this clash of civilizations and is (again) blind to the creeping danger of fascism, this time Islamofascism" (NRC, 19-06-2006).

This made it possible to limit freedom of speech and other Dutch values for the Muslim community by reference to their intolerant manner. In the aftermath of the recent terror attacks in 2014/15, the limits of tolerance and democratic power were questioned again.

\section{DISCUSSION}

This chapter analyzed how the emergence of populism has changed the meaning of tolerance in the public Islam debate and what this change means for the social and political conditions for integration in the Netherlands. An analytical framework was developed, that has been used for a TCA. Here, the value of this analytical framework will be discussed, after which it will be elaborate what the shifting meaning implies for the social and political conditions for integration in the Netherlands.

The analytical framework has helped to systematically analyze the different aspects that play a role in the creation of meaning regarding the term tolerance. It was found that change of meaning may be inferred through different discursive strategies. Those with the power to interfere may change the subject of tolerance, by framing a certain vulnerable group or individual as actor responsible for tolerance. Moreover, they have the option to change the object of tolerance which influences whether the subject of tolerance is seen as tolerant or intolerant. Further, tolerance is a value-laden concept with an underlying hierarchy of values that determines whether tolerance occurs. Those with the power to interfere may also define the limits of tolerance. Intolerance for intolerance is not a straightforward criterion for the limits of tolerance, because what is considered intolerant depends on the definition of the subject and object of tolerance as well as the 
hierarchy of values and is therefore at the disposal of those with the power to interfere. Finally, the analytical framework gives insights in the interdependent relationships between all five aspects of tolerance. The subject and the object are inevitable dependent on each other. Whether an object is tolerated is dependent on the subject's preference, while the chosen object may influence whether the subject is seen as tolerant or intolerant. Each subject of tolerance may have a different hierarchy of values that may be influenced by societal discourse. A shift in the hierarchy may influence which objects are considered objects of tolerance and whether they are tolerated. The power to interfere depends on who is framed as subject of tolerance and who has the power to influence the discourse.

The results of this research can be translated into relevant conclusions regarding the state of integration. First of all, the tolerance discourse has led to a broader range of subjects of (in)tolerance that can be held responsible by governance actors for a peaceful coexistence. Cooperation between these groups could be stimulated in order to create more tolerance. Likewise, framing a broad range of possible objects of tolerance may show that each actor in society relies on tolerance by others which may create more mutual tolerance. Yet, we need to be careful that the objects of tolerance are not used for further polarization and segregation in society. Uncovering artificial contradictions between different values that society seemingly needs to settle on can help to return to the original idea of individual emancipation and religious tolerance forming two sides of the same coin. In order to maintain societal peace, in cases where actual conflicts between values exist mutual understanding should be created between those affected and a tolerant middle ground should be found. Making one's own hierarchy of values explicit may help to create mutual understanding. With regard to the power to interfere, we see that while mainstream opinion leaders receive a greater platform for ventilating their ideas, populists manage to influence the debate by introducing their terminology and setting their agenda. This chapter may create consciousness among mainstream opinion leader about their role in reproducing the populist discourse. Finally, this chapter may stimulate the debate about the limits of tolerance as it has proven that no tolerance for intolerance is no clear delineation. While in the legal system the limits of tolerance are defined by law, societal limits of tolerance may be defined in day-to-day interactions. 


\section{APPENDIX: NEWSPAPER ARTICLES DIRECTLY QUOTED}

\begin{tabular}{|c|c|c|}
\hline Newspaper & Date & Title of the Article \\
\hline Volkskrant & $12-11-2004$ & Was het maar zo simpel! \\
\hline Volkskrant & 20-03-2010 & Wij nemen stelling \\
\hline Trouw & 02-02-2006 & Solidair met de Denen \\
\hline Telegraaf & $16-07-2007$ & Traditie \\
\hline Telegraaf & 23-09-2014 & $\begin{array}{l}\text { Meer geld tegen terreur; 'Vooral de schuld van de slappe overheid dat } \\
\text { dit gevaar nu levensgroot is' }\end{array}$ \\
\hline NRC & 16-03-2006 & No title (section: opinion) \\
\hline Trouw & $12-04-2010$ & SGP-vrouw wil geen seculiere barmhartigheid \\
\hline NRC & 02-01-2008 & Oproep op cover Trouw \\
\hline Trouw & 02-01-2008 & Benoemen en Bouwen \\
\hline NRC & $10-02-2006$ & $\begin{array}{l}\text { Aanvaard risico's van rol in Midden-Oosten; Europa ziet nu dat grotere } \\
\text { aanwezigheid in Afghanistan of Libanon gevolgen heeft }\end{array}$ \\
\hline NRC & $15-09-2007$ & $\begin{array}{l}\text { ledereen staat aan de kant; } \\
\text { Ivo van Hove, P.F. Thomése en Auke van der Woud over Prinsjesdag en } \\
\text { de Nederlandse politiek }\end{array}$ \\
\hline Volkskrant & 08-09-2012 & Ondoorgrondelijkheid in de Tweede Kamer hoort niet \\
\hline Trouw & $28-02-2005$ & Dales kondigt de liberale revolutie af 'Om de vrijheid' \\
\hline NRC & 10-03-2008 & Cartoonist: zend film Wilders uit \\
\hline Trouw & $26-10-2013$ & $\begin{array}{l}\text { Brussels tolerantie snoert ons de mond; Essay De EU perverteert tole- } \\
\text { rantie }\end{array}$ \\
\hline Volkskrant & 08-01-2015 & Dit is Theo van Gogh maal 12 \\
\hline Telegraaf & $15-06-2008$ & $\begin{array}{l}\text { Bos: Olieprijzen nooit meer laag; Geen compensatie voor middeninko- } \\
\text { mens }\end{array}$ \\
\hline Trouw & 23-08-2007 & No title (section: podium) \\
\hline NRC & 22-01-2007 & $\begin{array}{l}\text { Hervormer met zachte stem; Na jaren van strijd is Europese rehabilita- } \\
\text { tie van islamoloog Tariq Ramadan nabij }\end{array}$ \\
\hline Trouw & 21-05-2005 & Discrimineert Nederland? ; Onderzoek OVSE \\
\hline Volkskrant & 22-03-2005 & $\begin{array}{l}\text { Laten we liever dromen van een linkse Fortuyn; Wilders is keihard } \\
\text { rechts en dat wil hij weten ook }\end{array}$ \\
\hline NRC & 19-06-2006 & Haat is groter dan ooit \\
\hline
\end{tabular}




\section{REFERENCES}

ALBERTAZZI, D. \& MCDONNELL, D. 2008. Introduction: The Sceptre and the Spectre. In: ALBERTAZZI, D. \& MCDONNELL, D. (eds.) Twenty-First Century Populism. The Spectre of Western European Democracy. Basingstoke: Palgrave McMillan.

BARNUM, D. G. \& SULLIVAN, J. L. 1989. Attitudinal tolerance and political freedom in Britain. British Journal of Political Science, 19, 136-146.

BARNUM, D. G. \& SULLIVAN, J. L. 1990. The elusive foundations of political freedom in Britain and the United States. The Journal of Politics, 52, 719-739.

BERGGREN, N. \& ELINDER, M. 2012. Is tolerance good or bad for growth? Public Choice, 150, 283-308.

BOS, L. \& BRANTS, K. 2014. Populist rhetoric in politics and media: A longitudinal study of the Netherlands. European Journal of Communication, 29, 703-719.

BROWN, W. 2009. Regulating aversion: Tolerance in the age of identity and empire, Princeton University Press.

BURUMA, I. 2006. Murder in Amsterdam: The Death of Theo van Gogh and the Limits of Tolerance, New York, Penguin Press.

CEVA, E. \& ZUOLO, F. 2013. A Matter of Respect: On Majority-Minority Relations in a Liberal Democracy. Journal of Applied Philosophy, 30, 239-253.

COHEN, A. J. 2004. What Toleration Is. Ethics, 115, 68-95.

De Leeuw, M., and S. Van Wichelen. 2012. Civilizing Migrants: Integration, Culture and Citizenship. European Journal of Cultural Studies 15(2): 195-210. doi: 10.1177/1367549411432029.

FERRAR, J. W. 1976. The dimensions of tolerance. The Pacific Sociological Review, 19, 63-81.

FERRETTI, M. P. \& LAEGAARD, S. 2013. A Multirelational Account of Toleration. Journal of Applied Philosophy, 30, 224-238.

FORTUYN, P. 1997. Tegen de Islamisering van onze cultuur: Nederlandse identiteit als fundament, A.W. Bruna Uitgevers B.V.

GALEOTTI, A. E. 2015. The range of toleration: From toleration as recognition back to disrespectful tolerance. Philosophy \& Social Criticism, 41, 93-110.

GARZÓN VALDÉS, E. 1997. Some remarks on the concept of toleration. Ratio Juris, 10, 127-138.

GIBSON, J. L. \& BINGHAM, R. D. 1982. On the conceptualization and measurement of political tolerance. American Political Science Review, 76, 603-620.

GILSON, E. 1952/53. Dogmatism and Tolerance. International Journal, 8, 7-16.

GILROY, P. 1991. Sounds authentic: Black music, ethnicity, and the challenge of a" changing" same. Black Music Research Journal, 11, 111-136.

GRAY, J. 2000. Pluralism and toleration in contemporary political philosophy. Political studies, 48, 323-333.

IVANESCU, C. 2010. Politicised religion and the religionisation of politics. Culture and religion, 11, 309-325.

KORTEWEG, A., \& YURDAKUL, G. 2009. Islam, gender, and immigrant integration: Boundary drawing in discourses on honour killing in the Netherlands and Germany. Ethnic and Racial Studies, 32, 218238.

KUNDNANI, A. 2012. Multiculturalism and its discontents: Left, Right and liberal. European Journal of Cultural Studies, 15, 155-166.

LENTIN, A. \& TITLEY, G. 2012. The crisis of 'multiculturalism'in Europe: Mediated minarets, intolerable subjects. European Journal of Cultural Studies, 15, 123-138.

LIJPHART, A. 1979. Verzuiling, pacificatie en kentering in de Nederlandse politiek, Amsterdam, J. H. de Bussy. MEPSCHEN, P., DUYVENDAK, J.W. \& TONKENS, E.H. 2010. Sexual Politics, Orientalism and Multicultural Citizenship in the Netherlands. Sociology, 44, 962-979.

MONDAK, J. J. \& SANDERS, M. S. 2003. Tolerance and intolerance, 1976-1998. American Journal of Political Science, 47, 492-502.

MONDAK, J. J. \& SANDERS, M. S. 2005. The complexity of tolerance and intolerance judgments: A response to Gibson. Political Behavior, 27, 325-337.

MURPHY, A. R. 1997. Tolerance, toleration, and the liberal tradition. Polity, 29, 593-623.

NEHUSHTAN, Y. 2007. The Limits of Tolerance: A Substantive-Liberal Perspective. Ratio Juris, 20, 230-257.

NEWMAN, J. 1978. The idea of religious tolerance. American Philosophical Quarterly, 15, 187-195.

PAUWELS, T. 2014. Populism in Western Europe: Comparing Belgium, Germany and the Netherlands, Abingdon, Routledge. 


\section{THE INFLUENCE OF POPULISM ON TOLERANCE}

SEMETKO, H. A. \& VAlKEnBuRG, P. M. 2000. Framing European politics: A content analysis of press and television news. Journal of Communication, 50, 93-109.

SNIDERMAN, P. M. \& HAGENDOORN, A. 2007. When ways of life collide: Multiculturalism and its discontents in the Netherlands, Princeton University Press.

STOUFFER, S.A. 1966. Communism, Conformity, and Civil Liberties: A Cross-Section of the Nation Speaks Its Mind. John Wiley \& Sons, Inc.

SULLIVAN, J. L., PIERESON, J. \& MARCUS, G. E. 1993. Political tolerance and American democracy, Chicago, The University of Chicago Press.

TONKENS, E., HURENKAMP, M. \& DUYVENDAK, J. W. 2010. Culturalization of citizenship in the Netherlands. In: D’APPOLLONIA, A. C. \& REICH, S. (eds.) Managing Ethnic Diversity after 9/11: Integration, Security, and Civil Liberties in Transatlantic Perspective. New Brunswick: Rutgers University Press.

UITERMARK, J. L., MEPSCHEN, P. \& DUYVENDAK, J. W. 2013. Populism, Sexual Politics, and the Exclusion of Muslims in the Netherlands. In: BOWEN, J., BERTOSSI, C., DUYVENDAK, J. W. \& KROOK, M. L. (eds.) European States and Their Muslim Citizens. The Impact of Institutions on Perceptions and Boundaries. Cambridge: Cambridge University Press.

VAN DER HAAR, M. \& YANOW, D. 2011. Allochtoon als metafoor en categorie. Over de handelingsimplicaties van beleidstaal. Beleid en Maatschappij, 38, 160-178.

VAN DER NOLL, J. 2014. Religious toleration of Muslims in the German public sphere. International Journal of Intercultural Relations, 38, 60-74.

VAN GENUGTEN, S. 2013. The Netherlands and Islam: In Defence of Liberalism and Progress? The International Spectator, 48, 72-85.

VAN KESSEL, S. 2011. Explaining the electoral performance of populist parties: The Netherlands as a case study. Perspectives on European Politics and Society, 12, 68-88.

VERNON, R. \& LASELVA, S. V. 1984. Justifying Tolerance. Canadian Journal of Political Science, 17, 3-24.

VINK, M. P. 2007. Dutch 'multiculturalism'beyond the pillarisation myth. Political Studies Review, 5, 337-350.

VOGT, W. P. 1997. Tolerance \& education: Learning to live with diversity and difference, Thousand Oaks, Sage Publications, Inc.

VOSSEN, K. 2010. Populism in the Netherlands after Fortuyn: Rita Verdonk and Geert Wilders compared. Perspectives on European Politics and Society, 11, 22-38.

VOSSEN, K. 2012. From Marginal to Mainstream?: Populism in Dutch History. BMGN-The Low Countries Historical Review, 127, 28-54.

YOUNG, I. M. 1990. Justice and the Politics of Difference, Princeton, Princeton University Press. 


\section{Chapter}

\section{Mind the Gap: \\ Ethnic/Islamic Organizations between Multiculturalism and Assimilation}

If a German-Turkish comedian can go on the stage without addressing that he is German-Turkish - that is completed integration.

Kaya Yanar, German comedian of Turkish decent 


\section{Mind the Gap}

\section{ABSTRACT}

The Netherlands experience tension between the discourse of multiculturalism and the shift towards assimilation. Underlying this tension are questions over how disparate cultural groups in society relate to each other and how much space should be allowed for them to cultivate their unique cultural identities. The assimilation discourse requires complete adaptation of ethnic/Islamic minorities to Dutch culture. This chapter analyses how ethnic/Islamic organizations position themselves towards this request. Findings suggest that they reject assimilation on several grounds while constructing post-integration frames adjusted to meet a changing discourse. Indeed, while there is an admitted need for socio-economic, political and institutional post-integration, cultural and emotional frames largely resemble existing tensions between assimilation and multiculturalism.

Submitted to Identities as:

KURTH, L., DAVIDSON, M. \& GLASBERGEN, P. submitted May 2017. Mind the Gap: Ethnic/Islamic Organisations between Multiculturalism and Assimilation. 


\section{INTRODUCTION}

In the 2000s, leading politicians and scientists proclaimed the failure of multiculturalism: policies that focused on socio-economic participation of minority groups, but at the same time tried to preserve cultural diversity and concurrent adaptation in Western Europe (McGhee, 2008, Bauböck, 2002, Allen, 2007, Lentin and Titley, 2012, Kymlicka, 2010). Since then, the political discourse over integration ${ }^{1}$ has evolved to one of culturalization (Tonkens et al., 2010, Brown, 2009, Mepschen and Duyvendak, 2012). Culturalization of politics is based on the assumption "that every culture has a tangible essence that defines it and then explains politics as a consequence of that essence" (Mamdani, 2005, p.17). Some even forecast a return to policy aimed at a complete cultural adaptation, i.e. assimilation (Entzinger, 2006, 2014a, Vasta, 2007).

The Netherlands offers a clear example of this changing discourse on integration, where the debate is mainly focused on the religion of Islam and Turkish, Moroccan and Surinamese ethnic groups. On the one hand, research has shown that support for multiculturalism has remained largely stable between 1999 and 2007. On the other hand, however, the same research suggested that mainstream Dutch citizens "were somewhat negative about multiculturalism when it comes to adaptation and cultural maintenance by minority groups" (Breugelmans et al., 2008, p.664). Although most Dutch people accept cultural diversity and support the idea of equal opportunities and participation in society, many find that cultural pluralism is not favorable and acculturation is the responsibility of the minority. Facilitation of integration is not seen as a necessity by Dutch mainstreamers (Breugelmans and Van De Vijver, 2004). Also, since the 1980s several political figures have taken to the podium, demanding cultural assimilation of those with different ethnic or religious backgrounds. The identities of Muslims and ethnic groups are framed as opposed to Dutch liberal secularism, presumed to be based on a Judeo-Christian tradition. Therefore, this discourse follows the essentialist idea of Samuel Huntington's (1993) clash of civilizations.

The emerging contestation between the multiculturalism and the assimilation discourses deals with questions over how different cultural groups in society relate to each other and how much space is given to different cultural identities within the Dutch context. Polarization occurs between those requesting complete adaptation of all those with a non-Dutch cultural and a non-Judeo-Christian religious background and those who advocate preservation of cultural diversity. Much research has been devoted to this contradiction, e.g. with regards to policies and public opinion (e.g. Rodríguez-García, 2010, Verkuyten, 2006, Saharso and Lettinga, 2008, Duyvendak and Scholten, 2012, Tonkens et al., 2010). The strengthening assimilation discourse imposes responsibility for the adap-

\footnotetext{
${ }^{1}$ While the term 'integration' may have become biased through its use in the political realm, it is used in this study to describe the process of incorporating minority groups into the mainstream society. Different strategies of integration exist, e.g. multiculturalism or assimilation.
} 
tation to Dutch culture on the ethnic/Islamic minorities. Therefore, it is important to understand how these minorities position themselves between the multiculturalism and the assimilation discourse.

The ethnic/Islamic communities are highly diverse with several schools of Islam across a number of ethnic groups. In order to understand how they position themselves in the field of tension between multiculturalism and assimilation, this research focuses on Ethnic/Islamic organizations (E/IOs) at the national level. These organizations may not be representative of all members of the ethnic/Islamic communities, but they represent the major schools of thoughts and cultural backgrounds. A frame analysis, including problem definitions and proposed solutions, has been executed to grasp the diverse standpoints taken regarding integration.

Limited research exists regarding the views of E/IOs on integration in the Netherlands. Yukleyen (2009) examines the role of different Turkish umbrella organizations in developing a Dutch Islam, adjusted to the needs of the second and third generation of Turkish immigrants. He finds that Diyanet, Milli Görüş, Süleymanı and Gülen organizations in the Netherlands exhibit trends towards adaptation to local Dutch conditions. "Islamic organizations that are active in the public sphere, education, politics, or interfaith dialogue become more flexible and responsive to local conditions as they reinterpret the Islam to fit with local social and political circumstances" (p.306). Kortmann (2015) investigates the vision of Turkish Islamic umbrella organizations regarding integration and finds that, compared to German organizations, they tend to ask the state to withdraw from engagement to allow immigrants to take responsibility for their integration process. Indeed, they struggle against perceived demands for assimilation, preferring to support multiculturalism. Finally, Kortmann (2015) finds that Turkish umbrella organizations in the Netherlands place more emphasis on preserving their native identity rather than creating a hybrid identity. He explains these views with the Dutch political opportunity structure, e.g. multicultural policies and the growing perceived pressure for Muslim immigrants to assimilate. This study follows Kortmann, extending his research to include Moroccan, Surinamese and Dutch Islamic convert organizations and more elaborate frames of post-integration.

\section{DUTCH HISTORY OF INTEGRATION}

In order to understand the tension in public discourse between multiculturalism and strengthening assimilation, different approaches to integration in recent Dutch history must first be considered.

From Pillarization via Ethnic Minority Policies towards compulsory Integration.

In the second half of the $19^{\text {th }}$ century, the Netherlands developed a pillarized system in order to accommodate cultural diversity. This approach implied that society was sepa- 
rated along religious and ideological lines between protestants, Roman Catholics, socialists and liberals, with each pillar having its own institutions, such as media outlets, schools et cetera. financed equally by the state (Lijphart, 1986). There was an atmosphere of pragmatic tolerance among these pillars. This approach was abandoned in the second half of the $20^{\text {th }}$ century due to secularization and an increased level of education.

Since the 1950s, the Netherlands experienced an inflow of immigrants from its former colonies as well as from Italy, Spain, Portugal, Turkey, Greece, Morocco, Yugoslavia and Tunisia (Zorlu and Hartog, 2002). In the beginning, those with Mediterranean origin were encouraged to retain their cultural identity to ease the return to their home country. By the end of the 1970s, attention was drawn to controlling labor migration and family reunification (Sleegers, 2007). By the 1980s when government realized that these immigrants were intending to stay the ethnic minority policy was introduced. With the aim of fostering socio-economic equality, political inclusion and participation and cultural and religious equity of minorities, the policy involved a wide range of ministries (BruquetasCallejo et al., 2007). The approach recognized immigrants in terms of their group membership rather than as individuals. Highlighting their ethnic background, they came to be collectively designated as ethnic minorities (Entzinger, 2014a). In public discourse, cultural differences were not seen as a problem, but rather as enrichment (Sleegers, 2007). Whether out of pragmatism or due to ideological considerations, these policies may be understood as a form of multiculturalism, whereby the preservation of cultural identities is encouraged.

By the late 1980s and early 1990s, it became evident that the goals of these policies were not being met, as integration in the labor market was slow; educational achievements of migrant children were low; and segregation of housing emerged. Meanwhile, the leader of the conservative economically-liberal party VVD, Frits Bolkenstein, generated a public debate suggesting that Islam is a threat to liberal democracy and hinders integration (Vasta, 2007). In 1994, the upcoming liberal government introduced the new integration policy, promoting social participation, rather than cultural identity. This new approach placed culture in the private sphere, e.g. removing mother tongue classes from the school curriculum, and instead focused on integration in the job market. Unemployment rates among Turkish and Moroccan immigrants dropped to $10 \%$ by 2000 , which may seem like a success of the new policy, but it may also be accredited to the improved economic situation (Entzinger, 2014b). In fact, obligatory civic integration courses could not deliver the expected results regarding the Dutch language proficiencies. Interethnic contact decreased and concerns arose about the strong reliance of ethnic minorities on welfare provisions (Entzinger, 2006).

Rise of the Assimilation Discourse.

Bruquetas-Callejo et al. (2007), Vasta (2007) and Entzinger (2006, 2014b) found that in the early 2000s several events led to the dominance of the assimilation discourse in public and political debate. In 2000, sociologist and member of the social-democratic party 
Paul Scheffer (2000) published a news article in which he proclaimed the occurrence of $a$ multicultural drama. His article voiced concerns over stagnated integration by parts of society, segregation and a growing Islamic population. Scheffer argued that particularly the illiberal views of Muslims would undermine social cohesion and the functioning of liberal democracy and he accused Dutch elites of indifference over the matter. Instead of cultural relativism he proposed "more coercive policy efforts to overcome deprivation as well as stronger appeals on the immigrants to adapt to the principles of liberal democracy" (Scheffer in Entzinger, 2006).

Meanwhile, in the political arena, the Islam-critical Pim Fortuyn was on the rise, successfully employing the new public discourse for his political campaign. He requested to close the borders to prevent the influx of more immigrants, calling Islam a backward religion. Even though Fortuyn was killed before the 2002 elections, his party entered the government coalition. The unstable government was soon replaced by a center-right government which adopted a tough anti-immigration agenda, including more assimilatory integration policies. Acquiring Dutch citizenship became more expensive, the civic integration courses became privatized, toughened and subject to charges (Entzinger, 2006). Immigrants were blamed for their slow integration and little room was left for the public recognition of immigrants' cultural identity. Sleegers (2007) observed that between 1998 and 2003 most political parties had made a shift from appreciation of cultural diversity towards attention for the problems involved. Gradually, culture and religion became part of the political debate on integration and identity. Socio-economic problems that concerned newcomers gained less attention in political and public debate (WRR, 2007). "Many members of the native population continue(d) to consider Islam and its perceived expansiveness and oppressiveness as the root of all evil" (Entzinger, 2014b, p.700). The murder of film maker Theo van Gogh in 2004, the engagement of ex-Muslim and Islamcritic, Ayaan Hirsi Ali, in Dutch politics from 2004 to 2006, and Wilders strong anti-Islam agenda since 2006 fed into this perception.

From 2010 to 2012, Wilders' Islam-critical party Partij voor de Vrijheid (PVV) gave tacit support to a minority government, which resulted in an even tougher assimilation agenda, e.g. the consultation structure between the ethnic organizations and the government was dissolved and their funding was terminated. Even though the PVV has not been part of the government since 2012, many of the policy plans remained unchanged (Entzinger, 2014b). In the Dutch elections of March 2017, the campaign has been sparked with assimilation slogans, such as act normal or leave by Prime Minister Mark Rutte.

\section{METHODS}

This research follows the social constructivist tradition and for the data collection, thirteen qualitative semi-structured interviews have been held to gain in-depth information on national E/IOs framing of integration. In 2009, it was estimated that approximately $70 \%$ of the Dutch Muslim population had Moroccan or Turkish origins (Calculated using 
data from van Herten, 2009). As the Turkish community is more organized in E/IOs than the Moroccan community, five Turkish organizations and two Moroccan organizations are included in the sample. In order to also include the views of a group that came to the Netherlands due to colonial ties, a Surinamese organization was interviewed as well. While assimilation may be considered a request to foreigners, assimilation of Muslims implies that also Dutch converts to Islam have to assimilate. To gain deeper insights in this paradox, two organizations focused on converts are included in the sample. The Turkish and Moroccan contact body for the government and the Islamic contact body for the government were also interviewed. For a summary of all organizations included in the research, see Table 1.

Table 1: Interview respondents and their representation

\begin{tabular}{ll} 
Turkish & \\
Turks Islamitische Culturele Federatie (TICF) & Turkish Sunni (Diyanet) \\
Stichting Islamisch Centrum Nederland (SICN) & Turkish Sunni (Süleymancilar) \\
Nederlandse Islamitische Federatie (NIF) & Turkish Sunni (Milli Görüs) \\
HAK-Der & Turkish (Alevi) \\
Platform INS & Gülen movement \\
Moroccan & \\
Raad van Marokkaanse Moskeeën Nederland (RMMN) & Moroccan Sunni (Maliki) \\
Unie van Marokkaanse Moskeeorganisaties in Nederland (UMMON) & Moroccan Sunni (Maliki) \\
Surinamese & \\
World Islamic Mission & Surinamese Sunni \\
Converts & \\
Landelijk Platform Nieuwe Moslims (LPNM) & Converts/their environment \\
Stichting Bekeerling & Converts/their environment \\
(Former) contact bodies for the government & \\
Contactorgaan Moslims en Overheid (CMO) & \\
Inspraakorgaan Turken (IOT) & Duslims \\
Samenwerkingsverband van Marokkaanse Nederlanders (SMN) & Dutch Turks \\
\hline
\end{tabular}

For data analysis, a frame analysis was employed. A frame is the depiction of an event or situation from a specific point of view. When describing a situation, certain issues are emphasized while others are ignored "in such a way as to promote a particular problem definition, causal interpretation, moral evaluation, and/or treatment recommendation" (Entman, 1993, p.52). This process of frame creation (framing) is normative. It can be a subconscious process that simplifies and organizes reality or it may be strategically used to advance an interest (Shmueli et al., 2006). 


\section{CONTEXTUALIZING E/IOS IN THE NETHERLANDS}

The ethnic/Islamic communities in the Netherlands are very diverse and equally diverse and fragmented is the network of E/IOs. Each ethnicity has its own organizations that fulfil different functions in society and for the communities. On the local level, there are mosques foundations, religious and secular civil society organizations. Some of these organizations are organized on the regional level, while others are directly related to national umbrella organizations (UOs). In addition to religious UOs, at the national level there are also contact bodies for the government. Below, the different organizations and their network will be introduced along ethnic lines.

\section{Islamic Turkish E/IOs.}

Due to the fast-changing structure of the organizational field and the national focus of this research, the most recent report about Turkish religious groups and organizations in the Netherlands by Sunier and Landman (2014) is used for the contextualization of the Islamic Turkish IOs.

There are five major Turkish Islamic groups in the Netherlands. The Süleymancı were the first Turkish immigrant community requesting religious institutions in Europe in the early 1970s. By the 1980s the Netherlands counted 16 religious centers of the Süleymancı and nowadays the umbrella organization SICN, established in 1978, hosts 48 organizations. At the end of the 1970s, the Turkish-state run Diyanet extended its activities to the Netherlands and in 1979 established two UOs. ISN is officially responsible for all religious concerns, while TIFC deals with cultural and social concerns (Sunier and Landman, 2014). Even though in the last years ISN took over cultural and social concerns, the new management of TIFC is trying to reclaim its responsibilities (personal communication). With 146 mosques, ISN and TIFC form the largest Turkish Islamic UOs in the Netherlands. Milli Görüş, a Turkish religious-political movement, established an umbrella organization in the Netherlands in 1981, which in the late 1990s split into the two current organizations, Milli Görüş Nederland (MGN) in the North and the NIF in the South (Sunier and Landman, 2014). The former represents 22 mosques and the latter 18 (personal communication). The Gülen movement differs from the former three groups, as it does not follow an organizational structure of local Islamic organizations that belong to an umbrella organization. Instead, the Gülen network mainly organizes educational activities focused on young, highly educated people. The number of active supporters in the Netherlands is estimated to be a few thousand, but those reached by the activities are many more. Finally, the Alevis constitute $20-25 \%$ of the Dutch-Turkish population. They form a religious minority in Turkey that follows a liberal version of Shia Islam (Sunier and Landman, 2014). A number of local Alevi organizations established an umbrella organization (HAK-Der) in 1991 that is connected to the European confederation of Alevis in Cologne (van Heelsum et al., 2004). 
Islamic Moroccan E/IOs.

The organizational structure of the Islamic Moroccan E/IOs is researched much less recently and much less than its Turkish counterpart. The most recent information comes from a report examining Muslims in the Netherlands in 2004 (van Heelsum et al., 2004). According to this study, the first umbrella organization for Moroccan mosques was established in 1977 by local Islamic organizations in different cities across the country. The UMMON is said to follow the official Moroccan Islam, while the degree of royalty to the king differs. The UMMON does not work with official membership, but they have contacts with about 90 mosques (personal communication). Since 2006, there is a second umbrella organization for Moroccan mosques, the RMMN. On its website, four regional UOs are mentioned as members and in a personal communication, a representative of RMMN estimates that it covers about hundred mosques (personal communication).

Islamic Surinamese E/IOs.

In 1973 Surinamese Muslims in the Netherlands decided to establish an umbrella organization to represent the needs of its constituency to build and finance Surinamese mosques. For that purpose, the WIM was established (personal communication), which has 32 members (Bal and Sinha-Kerkhoff, 2006).

Islamic Dutch E/IOs.

Besides these UOs of foreign ethnic decent, today there are also Islamic Dutch organizations, focused on Dutch converts. On the national level, an organization was established in 2006/7 which connects individuals on a national level. However, considerations are currently made on whether to transform the LPNM into an umbrella organization for local organizations focusing on converts (personal communication). Moreover, there are internet-based organizations on the national level mainly aiming at provision of information about Islam. One such organization is Stichting Bekeerling which offers information about Islam to converts, their family and friends, and to anyone interested in Islam. Moreover, they offer a telephone hotline and info events in schools, hospitals and prisons (personal communication).

\section{Contact between Muslims and the Government.}

For every ethnic minority in the Netherlands, there was an organization representing the minority in a structural consultation with the national government, specifically with the Minister of Social Affairs and Employment. For the Turkish community, this was the IOT and the Moroccan community was represented by the SMN. However, during 2010-12 the government with tacit support of the PVV decided to stop the structural consultation with and the subsidies for ethnic minority organizations by $2015^{2}$. However, the IOT and the SMN still exist and aim at accommodating the needs of ethnic minority groups. In

${ }^{2}$ https://www.eerstekamer.nl/wetsvoorstel/33297_intrekking_van_de_wet 


\section{Mind the Gap}

addition to ethnically-organized organizations, since 1975 several inter-ethnic Islamic organizations have been established, usually in response to the government's demand for a contact point (van Heelsum et al., 2004). Since 2004, this function is fulfilled by the CMO, which involves both Diyanet-related organizations (ISN \& TIFC), both Milli Görüş organizations (NIF \& MGN), SICN, the UMMON, the WIM and the LPNM. The Turkish AIevis are represented by the humanistic contact committee instead of the $\mathrm{CMO}$. Neither the RMMN nor the Gülen movement is represented in the CMO. For an overview of the connections between the different organizations, view Figure 1.

Figure 1: Network of E/IOs

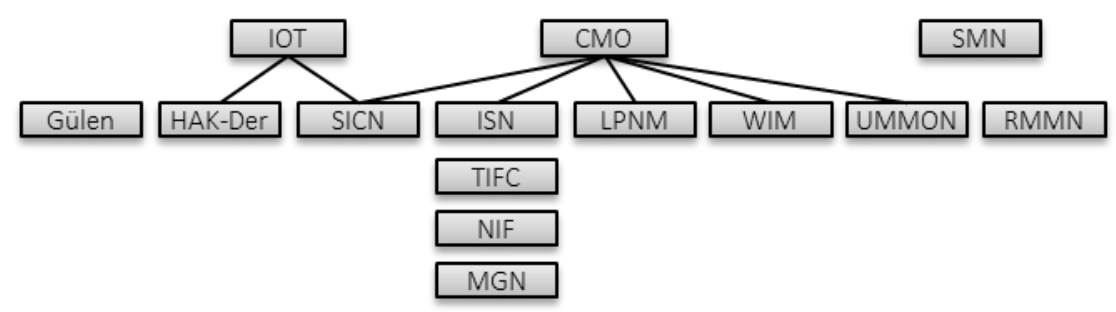

\section{ANALYSIS}

The sampled E/IOs have diverse frames with regards to integration. While none of the respondents presents one full-fledged frame, the frames have been created from the different interviews. Thus, each frame presented here is an aggregation of frames expressed by the respondents.

\section{Culturalization and Assimilation.}

Framing culture as the essence of political contestation leads to tensions within the frame of $E / I O s$ regarding their cultural identity. In the multiculturalism discourse, a cultural differentiation is needed in order to create separate cultural identities that may be preserved. However, the strengthening assimilation discourse uses culturalization to create dividing lines between enlightened Western values and backwards Islamic non-Western values. The $\mathrm{E} / \mathrm{IO}$ s seem to have an interest in preserving their cultural identity, while at the same time preventing to be blamed for problems of integration. This tension becomes visible in a contradictory frame that on the on hand emphasizes the differences in norms and values between the ethnic/Islamic communities and the rest of Dutch society, while on the other hand it rejects the responsibility for diverging values of their constituency. Further inquiry reveals that the phrase norms and values is often used to mean that the ethnic/Islamic communities follow different cultural and religious practices, but meanwhile comply with Dutch values. Consequentially, diverging norms and values may not be attributed to a cultural and religious identity. Besides, some respondents propose not to frame culture and religion as the essential defining identities that determine the 
behavior of minorities at all. Hereby, they oppose the culturalization of politics altogether.

Unanimity seems to prevail among the E/IOs that assimilation, defined as complete adaptation to Dutch values, is not desirable. Several reasons are giving for this opposition to assimilation:

Firstly, the assimilation discourse requires the adaptation of ethnic/Islamic minorities to the culture of Dutch majority. This would necessitate a streamlining of Dutch culture which infringes on Dutch liberal values, such as freedom of expression and freedom of religion. As one respondent phrased it: "You have to give up your complete background and you are almost forced to love kale. Every Saturday you have to eat sausages. Then others decide when you are integrated". This streamlining would allow no space for cultural identities anymore, which would deprive ethnic/Islamic communities of their identity. As one respondent explained: "Then I won't be me anymore, if I completely melt into society so that you cannot recognize me anymore". Instead, the E/IOs imagine the Netherlands as a county, where "everybody should have the freedom to be who he wants to be, if he does not compromise any laws or burdens society".

Secondly, if the assimilation discourse attempts to streamline society and asks ethnic/Islamic minorities to adapt to Dutch culture, a clear set of Dutch values is needed. As there is a lot of diversity within the Dutch society, such a set of values does not exist (yet). As a respondent explained: "if they say: 'That's all not allowed anymore.' What will replace it? Because politics does not have a clear answer to that, I am scared. Then I wonder: 'What do you want then?' It stays so vague. And then the prime minister says: 'We want you to behave normally.' What is normal?" Thus, even if the ethnic/Islamic minorities wanted to adapt to Dutch culture, it is unclear what that means.

Thirdly, by advocating a one-sided adaptation process, the assimilation discourse promotes an unequal balance of power and an ethnocentric attitude. A respondent argues that assimilation assumes "a semi-superior attitude by the one who says: 'I have been here longer than you. You are new, you have to adapt to my wishes'". This is especially unacceptable for those who have been born in the Netherlands and therefore have never known another home country. Another respondent adds that "in the process you have to grow together, but it is not a one-sided process. To give an example, everybody complains about black schools and segregation and that allochthone live in certain neighborhoods and stay in their own circle. But nobody complains about white schools and that autochthone stay in their own circle where they don't accept anyone else".

Finally, the assimilation discourse suggests that the values of ethnic/Islamic minorities essentially differ from the values of native Dutch. As discussed above, when E/IOs talk about different norms and values, in fact they often mean different practices based on similar values. A respondent explained that "if the government's policies are based on cultural values, then they are constantly pretending that these people (ethnic/Islamic minorities) are completely different from Dutch society". 
Yet, it is also acknowledged that future generations will naturally be more assimilated to Dutch society: "All migrants that form a minority in the Netherlands become assimilated. That's inevitable. My children for example speak bad Turkish; their Dutch is much better".

\section{Frames of Post-Integration.}

There is considerable agreement between the respondents that integration is an outdated concept that is useful for newcomers, but it does not apply to those immigrants that came to the Netherlands in the 1960/70 and their offspring. Therefore, the frames developed by the E/IOs are labelled post-integration frames. The five frames coincide with the different focuses taken by the government on integration in the past decades. The ethnic minority policies focused on the preservation of cultural identity and we can see that in this spirit $\mathrm{E} / \mathrm{IO}$ request the recognition of their cultural identity. The integration policy emphasized the socio-economic, institutional and political integration of the immigrants and the E/IOs have developed respective frames, acknowledging the challenges within their communities and proposing solutions. Finally, in the last decade the public discourse has shifted towards a culturalization of politics and also the E/IOs provide a cultural and emotional frame.

\section{Socio-economic Post-integration}

The socio-economic post-integration frame deals with social and economic participation. This can concern e.g. school attendance, work, and peaceful coexistence of different groups in society. All respondents agree that this form of integration is necessary. As a respondent explained: "if people speak the language, are well educated, comply with the laws and rules of the country, then they are integrated".

The E/IOs have developed a coherent socio-economic post-integration frame that entails clear problem reflections and the proposed solutions lead in the same direction. Responsibility for socio-economic integration is given to the ethnic/Islamic minorities as well as to Dutch society at large. For example, problems of participation, lacking language skills and low education, lack of knowledge about Dutch schooling practices by parents and certain Islamic practices that may disturb the work rhythm are attributed to the ethnic/lslamic communities. Yet, society is blamed for discrimination on the labor market and respective rejection of the minorities' altogether; poverty and its repercussions are mentioned as challenges for socio-economic integration rather than culture and religion; and the difficulty of Dutch institutions to reach segregated groups is acknowledged. Also, the suggested solutions take the ethnic/Islamic minorities, politics and society at large into responsibility. The former could organize empowering activities in mosques, provide information about rights and possibilities, represent the interests of socio-economic disadvantaged ethnic/Islamic minorities and reflect on and increase their own societal contribution. The government could make agreements with employers to decrease workplace discrimination, use a participatory approach to find solutions, fight housing and social 
segregation by increasing quality of schools and neighborhoods with a high minority concentration, improve institutional infrastructure for aid provision, stimulate a non-discriminatory public discourse, and assess Islamic organizations regarding their societal contribution rather than their reputation.

Political Post-integration.

The frame of political post-integration refers to the use of political rights such as the right to demonstrate, the right to vote and the right to run for office. As a respondent explains, political integration implies an "involvement with political events".

There is a coherent frame that advocates more political integration. The challenges of political integration are attributed to the ethnic/Islamic minorities and Dutch politics likewise. Lack of public representation and a low voter turnout among the ethnic/Islamic minorities are acknowledged. Proposed solutions are political representation of ethnic/Islamic minorities in parliament, the mobilization of ethnic/Islamic voters, and the empowerment of local ethnic/Islamic organization to participate politically. With regards to governmental responsibility, the political will and vision to support integration is questioned. A respondent explained that "politicians sometimes think: 'I'm going to choose some mosque members as candidates for my party, then we will receive a heap of votes.' That does not solve any problem, it is short-term thinking". Furthermore, E/IOs express the worry that double standards are used with regards to the desirability of public demonstrations, where demonstrations by ethnic minorities (e.g. pro-Erdogan) are seen as non-integration rather than as a sign of political participation. The respondent from SMN further suggests that since the stop of the structural consultation, the government lacks a sparring partner e.g. in the fight against radicalization. Proposed solutions are a new role for $\mathrm{E} / \mathrm{IOs}$ as policy advisor/executer, and a return to clear ideological distinction between established parties regarding integration instead of one dominant assimilation discourse.

\section{Institutional Post-integration.}

The frame of institutional post-integration entails citizenship, the compliance with Dutch law and the creation of own institutions within the state, such as mosques and Islamic schools. Respondents argue that "the rules of the game that we have agreed upon in the country are the criteria for integration" and "it is important that you are allowed to profess your belief in all freedom and you also have your facilities".

While the first two frames on post-integration were relatively coherent, the institutional post-integration frame entails conflicting sub-frames with regards to the institutionalization of mosques and religious schools. Some E/IOs representing ethnic mosques emphasize the importance of so-called homesickness mosques and the difficulties to finance them. In contrast, the respondent of the LPNM frames the ethnic affiliation as hindrance for integration and advocates foreign investment, e.g. from Qatar, for interethnic mosques. Solutions then also range from the request for governmental support for the construction of homesickness mosques to the allowance of foreign financing of culture- 
neutral mosques with media coverage as checks and balances. Another set of conflicting sub-frames exists regarding the question whether Islamic schools should exist. Some respondents argue that Islamic schools give Muslim children a strong Islamic identity and thereby empower them to find their place in society. Others advocate for mixed schools to enable integration and interreligious dialogue at an early age.

Besides these conflicting sub-frames, the $\mathrm{E} / \mathrm{IO}$ identified some institutional challenges and opportunities that are attributed to the ethnic/Islamic community and the broader society. Understanding exists for the fear of the minorities to lose the right to execute religious practices as well as for the fear of non-Muslims that their current life style may be threatened by e.g. the construction of mosques. Proposed solutions involve better communication about the compliance of Muslims with Dutch laws, while simultaneously following Islamic norms. Resistance by the non-Islamic population against the construction of mosques could be dissolved by interreligious dialogue, local community activities, and transparency of mosques.

Cultural Post-integration.

Compared to the first three frames, the cultural and emotional frame are direct responses to the assimilation discourse. The frame of cultural post-integration is related to the acceptance of certain common values by all members of society, e.g. gender equality, democracy and rule of law, non-discrimination, and tolerance.

The contradicting sub-frames regarding cultural post-integration resemble the tensions between the assimilation and the multiculturalism discourse. Sub-frames range from support for the development of a Dutch Islam combined with Dutch culture to the preservation of ethnic Islamic traditions from Turkey, Suriname or Morocco. The frame closest to cultural assimilation argues that the merging of culture and religion of the country of origin prevents connecting with Dutch society. As a respondent explained: "As long as you cling to the culture of Morocco it becomes difficult to integrate, because you do not get a common culture". This frame is based on the idea that being Muslim is the identity that ought to be preserved, not an ethnic identity. According to adherents of this frame, Islam offers a lot of freedom to adjust to any culture. Thus, cultural integration would imply merging Islam with Dutch culture and creating Dutch Islam. For that each ethnicity should bring its positive cultural aspects to the table to create a common culture fit for Dutch private and public sphere. One respondent suggested that the current Islamic organizations may get dispersed and new networks are created "for liberal Muslims, for orthodox Muslims and all kinds of religious orientations". In the other main frame, culture and religion are so indivisibly intertwined that an adaptation to Dutch culture is perceived as a loss of Islamic beliefs. Problems of cultural integration are then identified in terms of fear to lose one's religious background. As a respondent expressed it: "That is the fear of Muslims that they have to omit their religion, that they are not permitted to pray and that they have to drink beer". Challenges of cultural integration 
are then seen in the lack of acceptance of multiple identities, including an ethnic and a Dutch identity.

\section{Emotional Post-integration.}

The frame of emotional post-integration requires that ethnic/Islamic minorities feel at home in the Netherlands, while native Dutch feel that they are not losing their known environment. It entails the existence of an all-encompassing feeling of common identity across ethnic and religious lines and a focus on a common future.

As emotions are influenced by a complex set of internal and external circumstances, all problems and solutions mentioned in the other post-integration frames play a vital role in the emotional frame. Like in the other frames, also in the emotional post-integration frame responsibility has been distributed between the ethnic/Islamic minorities and society at large. Here, two contradicting sub-frames have developed. The first one is based on the idea that ethnic/Islamic minorities are not accepted by the native Dutch society. Discrimination and rising populism lead members of the minorities to turn away from Dutch society towards traditions of their country of ethnic origin, orthodox Islam or even radicalize. As a respondent explained: "When you are not accepted, you rebel against the established order, and you crawl back into your shell. Thus, there are groups within the Turkish, Moroccan and Surinamese community, even from the third or fourth generation, which are entirely focused on the old traditions of their ancestors". Problems identified from within this sub-frame are a lack of feeling Dutch and the rejection by the Dutch society as well as by the host country. A disconnection between the minorities and the native Dutch has been noticed. Furthermore, self-victimization has been identified as a problem of this sub-frame and the radicalization of youth that does not feel accepted. The second sub-frame reverses the causality of the first sub-frame by arguing that the focus on the country of ethnic origin leads to a lack of integration in the Netherlands. Loyalty to another country is framed as a lack of investment into the Netherlands. The technological advancement that eases communication and connection with the country of origin are blamed for slow emotional integration.

Besides these two frames based on different responsibilities, a third sub-frame is developed mainly by second and third generation ethnic/Islamic immigrants. They consider integration an outdated concept, as most ethnic/Islamic minority members have Dutch citizenship and should be treated as such with equal rights and duties. Problems are detected with regards to the acceptance by the native Dutch population of their fellow citizens. An exclusionary discourse is noticed that exemplifies itself in calls to "take away your passport and you are not welcome anymore". Within this sub-frame, problems of socio-economic participation and cultural emancipation, as well as lacking abilities to communicate belonging are acknowledged. A frame that describes the Islamic identity as the dominant identity for all Muslims, ignoring their identity as teachers, fathers etc. and blaming Islam for all these problems is rejected. 
Proposals for a better emotional integration involve the ethnic/Islamic minorities and societal actors that are open to bridge the gap. Solutions entail empowerment and individual responsibility of ethnic/Islamic minorities instead of (self-) victimization, while expecting acceptance of cultural diversity by society at large. The need for the creation of common future goals and a common identity is emphasized, which can be achieved through interreligious and intercultural dialogue, a focus on common values rather than dividing factors, and joint contribution to societal welfare by multiple actors. Converts and other emotionally integrated members of the ethnic/Islamic minorities are assigned as bridge builders and the media could play a role by presenting a more positive view of integrated Muslims rather than focusing on negative examples. Synergies between the silent majorities within the ethnic/Islamic minorities and within Dutch society should be found and used to create a common post-integration discourse.

\section{DISCUSSION \& CONCLUSION}

The objective of this chapter is to understand how ethnic/Islamic minorities position themselves between the multiculturalism and the assimilation discourse. These discourses deal with the questions how different cultural groups in society relate to each other and how much space is given to different cultural identities within the Dutch context.

It is worthwhile to recognize that a network of national E/IOs exists which starts to take part in the debate about integration. The organizational landscape of the ethnic/lslamic minorities is diverse, entailing mosque and societal foundations on the local level and national umbrella organizations and representations towards the government. The Turkish community is exhibiting a greater degree of organization than Moroccans and Surinamese. The former is organized along religious lines and collaboration between the organizations is partly influenced by their political affiliation in Turkey, e.g. cooperation between the Diyanet-related organizations and the Gülen movement have been hampered after the attempted coup in Turkey in July 2016. Moroccans mainly work with key figures in the community instead. The ethnic contact bodies with the government, IOT and $\mathrm{SMN}$, present themselves as alternative to the national mosque UOs to reach the ethnic/Islamic community, while this claim has been rejected by some of these religious organizations.

The analysis has shown that the frames developed by these E/IOs reflect the different approaches that have been taken by the government regarding integration since the 1980s. Thus, we can conclude that the E/IOs adjust to the leading public discourses and develop possible responses. However, even though the current dominant discourse aims at assimilation, the frames of the $\mathrm{E} / \mathrm{IO}$ are still based on the premise that cultural identity ought to be preserved and room should be given to cultural and religious expression. Corresponding with Kortmann (2015), this research shows that the E/IOs reject the demand for assimilation and request the acceptance of cultural diversity. Agreement exists 
that socio-economic, political and institutional integration are necessary. Even concerning cultural and emotional integrations, sub-frames exist that advocate partial adaptation, e.g. the development of an interpretation of Islam that may be combined with Dutch culture. In line with the findings of Yukleyen (2009), this research has found that there are possibilities for adjustment of Islamic traditions to the local social and political context. However, we have also seen that there is a contradicting sub-frame that defends the preservation of the connection between foreign ethnic traditions and Islam and thereby hamper the development of a Dutch Islam. Still, most respondents agreed that the difference to Dutch culture mainly consist in the practices rather than in norms and values.

One important aspect in the $\mathrm{E} / \mathrm{IO}$ framing of post-integration is the responsibility for the process of post-integration. While the assimilation discourse claims the privilege for defining the space for cultural diversity, the responsibility for adaptation is solely imposed on the ethnic/Islamic minorities. Most E/IOs refuse this idea of one-sided, imposed adaptation and emphasize in all frames that post-integration requires adaptation and acceptance from themselves, government, and society at large. Contrary to the finding by Kortmann (2015) that Turkish UOs request the government to withdraw from engagement with integration, this study revealed a diversity of options to overcome challenges of integration, some of which requiring governmental involvement. Resources to create a post-integration discourse are seen in a coalition with those powers that support a reasonable preservation of cultural identities, while encouraging a two-sided adaptation process.

There are, however, certain aspects of the frames of post-integration that could aggravate the development of a new discourse. First of all, the post-integration frames challenge the existing power balance whereby the acceptance of immigrants is at the mercy of the majority. The frames of the $\mathrm{E} / \mathrm{IO}$ s request acceptance by the native majority as a precondition for a two-sided approach to integration. The assimilation approach instead maintains the power balance between the native majority and the ethnic/Islamic minorities requesting a complete one-sided adaptation of the minorities to what is called Dutch culture.

Secondly, in the light of the culturalization of politics, the incoherence of the cultural and emotional frames could lead to an internal resistance against such a new discourse. For example, those holding onto Turkish, Moroccan and Surinamese cultural traditions and those in support of a Dutch Islam could inhibit each other. Frame alignment may become possible through debate between the different actors in the ethnic/Islamic community. Dividing lines seem to exist between different generations, between ethnic and native Dutch Muslims, and between the representatives of mosques and contact bodies towards the government.

In general, it can be concluded that E/IOs position themselves moderately between the multiculturalism and the assimilation discourse, acknowledging their own capacities for adaptation, while requesting a two-sided process of post-integration on a levelled 
playing field. Future research ought to focus on strategies through which E/IOs attempt to influence the public discourse in practices by analyzing their communication strategies and activities. Furthermore, future research should investigate how Dutch mainstream citizens position themselves with regards to assimilation and post-integration.

\section{REFERENCES}

ALLEN, C. 2007. 'Down With Multiculturalism, Book-burning and Fatwas' The discourse of the 'death' of multiculturalism. Culture and religion, 8, 125-138.

BAL, E. \& SINHA-KERKHOFF, K. 2006. Muslims in Surinam and the Netherlands, and the Divided Homeland. Journal of Muslim Minority Affairs, 25, 193-217.

BAUBÖCK, R. 2002. Farewell to multiculturalism? Sharing values and identities in societies of immigration. Journal of International Migration and Integration/Revue de l'integration et de la migration internationale, 3, 1-16.

BREUGELMANS, S. M. \& VAN DE VIJVER, F. J. 2004. Antecedents and components of majority attitudes toward multiculturalism in the Netherlands. Applied Psychology, 53, 400-422.

BREUGELMANS, S. M., VAN DE VIJVER, F. J. \& SCHALK-SOEKAR, S. G. 2008. Stability of majority attitudes toward multiculturalism in the Netherlands between 1999 and 2007. Applied Psychology, 58, 653-671.

BROWN, W. 2009. Regulating aversion: Tolerance in the age of identity and empire, Princeton University Press.

BRUQUETAS-CALLEJO, M., GARCÉS-MASCAREÑAS, B., PENNINX, R. \& SCHOLTEN, P. 2007. Policymaking related to immigration and integration. The Dutch Case. Amsterdam: IMISCOE Working Papers.

DUYVENDAK, J. W. \& SCHOLTEN, P. 2012. Deconstructing the Dutch multicultural model: A frame perspective on Dutch immigrant integration policymaking. Comparative European Politics, 10, 266-282.

ENTMAN, R. M. 1993. Framing: Toward Clarification of a Fractured Paradigm. Journal of Communication, 43, 51-58.

ENTZINGER, H. 2006. Changing the rules while the game is on: From multiculturalism to assimilation in the Netherlands. In: BODEMANN, Y. M. \& YURDAKUL, G. (eds.) Migration, citizenship, ethnos. Palgrave Macmillan US.

ENTZINGER, H. 2014a. The rise and fall of multiculturalism: The case of the Netherlands. In: JOPPKE, C. \& MORAWSKA, E. (eds.) Toward assimilation and citizenship: Immigrants in liberal nation-states. Palgrave Macmillan UK.

ENTZINGER, H. 2014b. The growing gap between facts and discourse on immigrant integration in the Netherlands. Identities, 21, 693-707.

HUNTINGTON, S. P. 1993. The clash of civilizations? Foreign affairs, 72, 22-49.

KORTMANN, M. 2015. Asking Those Concerned: How Muslim Migrant Organisations Define Integration. A German-Dutch Comparison. Journal of International Migration and Integration, 16, 1057-1080.

KYMLICKA, W. 2010. The rise and fall of multiculturalism? New debates on inclusion and accommodation in diverse societies. International social science journal, 61, 97-112.

LENTIN, A. \& TITLEY, G. 2012. The crisis of 'multiculturalism'in Europe: Mediated minarets, intolerable subjects. European Journal of Cultural Studies, 15, 123-138.

LIJPHART, A. 1986. Verzuiling, pacificatie en kentering in de Nederlandse politiek, Amsterdam, De Bussy

MAMDANI, M. 2005. Good Muslim, bad Muslim: America, the Cold War, and the roots of terror, New York, Three leaves press doubleday.

MCGHEE, D. 2008. End of Multiculturalism: Terrorism, Integration and Human Rights, McGraw-Hill Education (UK).

MEPSCHEN, P. \& DUYVENDAK, J. W. 2012. European sexual nationalisms: The culturalization of citizenship and the sexual politics of belonging and exclusion. Perspectives on Europe, 42, 70-76.

RODRÍGUEZ-GARCÍA, D. 2010. Beyond Assimilation and Multiculturalism: A Critical Review of the Debate on Managing Diversity. Journal of International Migration and Integration 11, 251-271.

SAHARSO, S. \& LETTINGA, D. 2008. Contentious citizenship: Policies and debates on the veil in the Netherlands. Social Politics: International Studies in Gender, State \& Society, 15, 455-480.

SCHEFFER, P. 2000. Het multiculturele drama. nrc Handelsblad.

SHMUELI, D., ELLIOTT, M. \& KAUFMAN, S. 2006. Frame changes and the management of intractable conflicts. Conflict Resolution Quarterly, 24, 207-218. 
SLEEGERS, F. 2007. In debat over Nederland. Veranderingen in het discours over de multiculturele samenleving en nationale identiteit. Amsterdam: Wetenschappelijke Raad voor het Regeringsbeleid.

SUNIER, T. \& LANDMAN, N. 2014. Turkse islam. Actualisatie van kennis over Turkse religieuze stromingen en organisaties in Nederland. Een literatuurstudie in opdracht van het Ministerie van Sociale Zaken en Werkgelegenheid.

TONKENS, E., HURENKAMP, M. \& DUYVENDAK, J. W. 2010. Culturalization of citizenship in the Netherlands. In: D’APPOLLONIA, A. C. \& REICH, S. (eds.) Managing Ethnic Diversity after 9/11: Integration, Security, and Civil Liberties in Transatlantic Perspective. New Brunswick: Rutgers University Press.

VAN HEELSUM, A., FENNEMA, M. \& TILLIE, J. N. 2004. Moslim in Nederland: islamitische organisaties in Nederland. Den Haag: Sociaal en Cultureel Planbureau.

VAN HERTEN, M. 2009. Religie aan het begin van de 21ste eeuw, Den Haag/Heerlen, Centraal Bureau voor de Statistiek.

VASTA, E. 2007. From ethnic minorities to ethnic majority policy: Multiculturalism and the shift to assimilationism in the Netherlands. Ethnic and racial studies, 30, 713-740.

VERKUYTEN, M. 2006. Multicultural recognition and ethnic minority rights: A social identity perspective. European Review of Social Psychology, 17, 148-184.

WRR 2007. Identificatie met Nederland, Amsterdam University Press.

YUKLEYEN, A. 2009. Localizing Islam in Europe: religious activism among Turkish Islamic organizations in the Netherlands. Journal of Muslim minority affairs, 29, 291-309.

ZORLU, A. \& HARTOG, J. 2002. Migration and immigrants: the case of the Netherlands. Sudies and Comments 1: Migration policy and the economy: international experiences [Online]. 


\section{Chapter}

\section{Conclusion}

The consequences of our actions are so complicated,

so diverse, that predicting the future is a very difficult business indeed.

$\sim$ J.K. Rowling 


\section{CONCLUSION}

\section{INTRODUCTION}

This dissertation starts with the observation of a contestation about the space for cultural diversity and identities in the Netherlands. Tensions occur between followers of the assimilation discourse and those who support multiculturalism.

The assimilation discourse is based on the idea that minorities should completely adapt to majority culture for social cohesion to be preserved (Ager \& Strang, 2008; Rodríguez-García, 2010). Assimilatory policies prohibit cultural expressions of the minorities and eliminate or localize social services that promote the integration process (Mitchell, 2004).

Multiculturalism acknowledges and protects cultural identity and diversity (Rodríguez-García, 2010) by granting group rights to minorities (Bloemraad et al., 2008). Multiculturalist policies, for example, integrate cultural diversity in the school curriculum and allow for dual citizenship (Bloemraad, 2007).

Tensions between these two discourses and policy approaches manifest themselves in different societal spheres, such as the government, civil society and the economy. In the Netherlands, Islamic traditions and symbols form a specific object of contestation. Public and political debate deals with controversies about the headscarf, the construction of mosques, ritual slaughter, halal food etc. This study examined several case studies of such debates to answer the following research questions:

How do different societal actors position themselves with regards to the space given for cultural identity and diversity?

Which opportunities and barriers do these actors encounter in different societal spheres and how can these be explained?

What are the consequences of the findings of the two former questions for the discourses on integration?

The first case study deals with the parliamentary debate about non-stunned ritual slaughter in the Netherlands and analyzes how politicians position themselves with regards to space for cultural identity. The second research studies how halal certification businesses accommodate the needs of the Islamic community. The third study analyzes how populism has change the meaning of Dutch tolerance and what that means for the integration discourse. The last study focuses on how ethnic/Islamic organizations position themselves between assimilation and multiculturalism.

This conclusion aims at answering the three main research questions of the dissertation using the results of the four case studies and it offers a research reflection. 


\section{HOW DO DIFFERENT SOCIETAL ACTORS POSITION THEMSELVES WITH REGARDS TO THE SPACE GIVEN FOR CULTURAL IDENTITY AND DIVERSITY?}

This research shows that the positioning with regards to assimilation and multiculturalism is a complex issue, involving various interests using different reasons. The difference between the private sphere in which people can experience their own cultural identity and the secular public sphere has become blurred by the arrival of Muslims in the Netherlands. People started to realize that what was considered a secular public sphere was by no means secular, but based on the Christian traditions. The fact that the weekend consists of Saturday and Sunday has developed from the Christian tradition that Sunday is the day on which God rested after he had created the world. In Islam, the holy day for prayer and resting is Friday. Moreover, school holidays during Christmas and Eastern, as well as the ringing of church bells, are accommodating the need of the Christian tradition. The highest feasts of Islam mainly take place during and around Ramadan and mosques traditionally have a call for prayer by the muezzin. Even in politics, we see that the Netherlands accommodates three Christian parties in parliament. While Muslims are also allowed to establish their own party, this appears to be difficult for them. Besides the realization that the Dutch public sphere is far from secular, several issues traditionally belonging to the private sphere have been brought into public discourse. For example, food consumption patterns and clothing were in the past considered individual decisions in the private sphere. However, in the last years we have seen public debates about ritual slaughter and halal food consumption as well as the wearing of headscarves and niqap. Taking positions with regards to all these new developments is extremely difficult and politically sensitive. A few issues influencing the positions taken have become particularly apparent during the research for this dissertation.

\section{Taking responsibility.}

One aspect that appears of importance is the question who should take responsibility for the extent to which space is granted for cultural identity. In the study about ritual slaughter in Chapter 2, we see that politicians tend to involve legal provisions, the political game, science and economics in their decision-making process. One might say that they are looking for rational secular arguments, but they are also shifting responsibility for a political decision towards the courts, between each other and towards the business sector. Scientific reports are used by several actors throughout the political spectrum to support their own moral arguments.

The research in Chapter 3 shows that there are several actors that want to take responsibility to fulfill the needs of Muslims to express their cultural identity by eating halal food. However, due to economic considerations these actors are hardly adaptive to the diverse needs of the Dutch Muslim community and rather focus on the international market. 


\section{CONCLUSION}

As Chapter 5 shows, ethnic/Islamic organizations take a clear stance with regards to assimilation and multiculturalism. They see a common responsibility for successful integration by the government, ethnic/Islamic organizations and society at large.

Chapter 4 about tolerance suggests that the shifting tolerance discourse in the Netherlands offers new opportunities to assign responsibility for peaceful coexistence in an atmosphere of mutual tolerance to all societal groups as each of them might become an object that needs tolerance at some point in time. This is related to Rawls (Rawl, 1971) idea of the vail of ignorance, which implies that one should only support restrictions of freedom that seem favorable independent of one's own position in society. Furthermore, this study shows that mainstream opinion makers can have a great impact on the discourse of tolerance.

\section{Commodification of space for cultural identity.}

An additional issue that we see especially with regards to ritual slaughter and halal food is the commodification of space for cultural diversity. One of the main arguments in the parliamentary debate about non-stunned ritual slaughter was that a prohibition would lead to economic losses and that the production of Dutch halal and kosher meat would be outsourced to neighboring countries. Following this line of reasoning, space for the expression of cultural identity would be given for economic reasons rather than as a moral obligation to ensure freedom of religion. Also, the research on halal certification shows that economic considerations play an important role in the provision of products that are needed to follow specific Islamic traditions. The standards for halal food production are not adjusted to the various requirements arising from the different ethnic and religious backgrounds of Muslims in the Netherlands. Instead, they are aligned with the prescriptions of the Malaysian and Indonesian food market, which provides the largest export market.

\section{Path dependency.}

Path dependency relates to the idea that historical events matter for decisions taken today. We can see that this is the case with regards to the positioning of different actors between assimilation and multiculturalism. The fact that ritual slaughter had only ever been prohibited during the Second World War had an effect on the space given to religious minorities regarding their food practices. Some even argue that if the Jewish community had not been affected by the law, the space for Muslims to practice non-stunned ritual slaughter might have been eliminated. Chapter 4 reveals that the populist framing of Muslims as intolerant since the 1980s, but especially after the events of $9 / 11$, has influenced the tolerance debate in the Netherlands and shifted the entire definition of tolerance. Muslims are increasingly framed as intolerant towards other minorities such as women or homosexuals. Also in Chapter 5, we see that policy decisions taken in the past influence the post-integration frames developed by ethnic/Islamic organizations in the present. Past policies focused on socio-economic, political and institutional integration 
and the recent emphasis on cultural and emotional integration are reflected in the socioeconomic, political, institutional, cultural and emotional post-integration frames.

\section{WHICH OPPORTUNITIES AND BARRIERS DO ACTORS ENCOUNTER IN DIFFERENT SOCIETAL SPHERES AND HOW CAN THESE BE EXPLAINED?}

The actors involved in the different societal spheres may encounter opportunities and barriers with regards to different aspects of positioning. First, there are opportunities and barriers in taking a position, e.g. conflicting interests. Secondly, certain factors might make it easier or more difficult to express an opinion effectively, e.g. power to influence the media. Finally, opportunities and barriers exist in finding common ground to define the space given to cultural identity, e.g. conflicting worldviews between actors.

\section{Taking a position.}

Taking a position regarding the space given to cultural identity is particularly difficult when different interests have to be accommodated. Chapter 2 illustrates that politicians in a politically sensitive debate, such as the prohibition of ritual slaughter, struggle to take a position. This may be explained through their dependence on and their responsibility to represent their electorate, while at the same time they have the duty to protect minorities. In the current discourse of assimilation, the majority might value animal welfare higher than the freedom to slaughter animals in a religiously prescribed form. Therefore, it is difficult for politicians to please the majority while protecting minority rights. We see a similar conflict of interests in Chapter 3. The creation of standards adapted to the needs of the diverse Dutch Muslim community would mean economic losses for the certifiers, as their standards would not be internationally recognized. For that reason, it is difficult for the halal certifiers to take a position that allowed space for cultural identity through the purchase of halal food under economic and international pressure. Such conflicts of interests may be avoided by focusing on the civil society, which does not operate under the pressure of political accountability or economic interest. For example, in Chapter 5 we observe that ethnic/Islamic organizations take a position between multiculturalism and assimilation rather independently, but still respond to the dominant policy discourse of the government. Furthermore, accommodating the needs of the Islamic minority on the local level and on an individual base may solve economic tensions. Indeed, Dutch Muslims keep buying meat and other products from their local cultural supermarket on the basis of trust.

\section{Expressing a position.}

The research for this dissertation shows that power differences and the ability to influence the public debate affect the way positions regarding space for cultural identity may be expressed. 


\section{CONCLUSION}

In the political process in parliament, every party gets the opportunity to express its position regarding a topic. However, Chapter 2 also shows that the influence of interest groups affected the outcome of the legislative debate about pre-stunned ritual slaughter. Not all interest groups are equally able to access the political process. While animal welfare organizations have a representative party in parliament and the Jewish minority in the Netherlands is well organized, the less well-organized Islamic minorities find it difficult to convey their position.

In the economic sphere, certifiers have the opportunity to utilize commercials to publicize their brand value. Furthermore, they can publish their standards and procedures openly on their website and cooperate with Dutch supermarkets to create awareness for their commitment to facilitate the needs of the Dutch Muslim community. Instead, Dutch halal certifiers choose to operate in an opaque governance system without stakeholder involvement.

While the media gives more room to those taking a moderate viewpoint regarding the space allowed for cultural identities, populists manage to influence the debate by introducing their terminology and setting their agenda. This leads to a discourse in which Muslims are framed as subjects of intolerance. The populist approach of victimizing the majority, while blaming the political elites and Muslims for intolerance, makes it difficult to create a powerful counter-discourse. The attempt to create a counter-discourse may be judged as intolerance.

As explained above, ethnic/Islamic organizations are independent from political accountability claims and economic interests when taking positions. However, they represent the interests of internally diverse minorities in Dutch society. For that reason, they may have difficulties to create a counter-discourse to the public assimilation discourse. Their post-integration discourse, described in Chapter 5, involves a transformation of the current power balance whereby post-integration becomes a two-sided process of adaptation. Moreover, the frames of various ethnic/Islamic organizations are incoherent, especially with regards to the possibility and responsibility for cultural and emotional postintegration.

\section{Finding common ground.}

While taking a position may be problematic if one actor faces conflicting interests, finding common ground becomes even more difficult when several actors have different and at times conflicting interests, positions and worldviews. Furthermore, differences in power position and the ability to influence the discourse can determine in how far common ground may be found.

In the political sphere of the parliament, common ground is usually sought through deliberation and voting which results in a majority decision. This was also the case with regards to the draft legislation about non-stunned ritual slaughter where the Lower House voted in favor of a prohibition and the Upper House rejected the bill. This decision could have let to the religious minorities retaining their freedom of religion, while the 
opposing positions, mainly focused on animal welfare, would be ignored. However, in this specific case, a compromise in the form of a covenant between the Dutch government and those religious minorities in need of non-stunned ritual slaughter was found. This covenant is a voluntary obligation of the kosher and halal slaughter houses to comply with specific animal welfare standards. It offers the possibility to reconcile animal welfare concerns with the needs of the religious minorities.

The halal certifiers in Chapter 3 have not found a way yet, to reconcile the diverse needs of the Dutch Muslim community with their economic interest of market expansion and respective compliance with foreign standards. However, the Muslim community mainly fulfills its needs by buying products from local markets based on trust relationships with the sellers. If the demand for halal food grows, the Dutch Muslim community might gain the power to request a transparent system of halal governance adjusted to their diverse needs.

Whereas it is often argued that populism leads to a polarization in society, the changing meaning of tolerance in Dutch media also opens up opportunities to find common ground. In Chapter 4, we see that several actors are identified who may be requested to practice tolerance, e.g. Dutch majority, Muslims, secularists and populists. Moreover, various groups are recognized that are in need of tolerance, e.g. homosexuals, women and apostates. This shows that all actors in society are responsible for enhancing tolerance and may also be in need of tolerance for their own position. Furthermore, making hierarchy of values explicit can create mutual respect and uncover artificially constructed contradictions. Yet, the changing meaning of tolerance may also be used to further polarize and segregate society.

In Chapter 5, we see that opportunities and barriers exist regarding finding common ground between the ethnic/Islamic organizations and in their relation to the public assimilation discourse. Conflicting interests between the organizations occur particularly with regards to cultural and emotional integration. While those representing so-called homesickness-mosques aim at preserving cultural identities from Turkey and Morocco, convert organizations request the development of a Dutch Islam adjusted to local culture. Besides, ethnic/Islamic organizations reject the public demand for assimilation, requesting space for their cultural and religious identity. Especially second and third generation Islamic immigrants ask for acceptance on equal footage rather than debates about failed integration. Opportunities for finding common grounds are seen in an open and honest debate within the Islamic communities about the space needed for cultural identity and the ability for adaptation. Moreover, a possibility is envisioned for collaboration between the ethnic/Islamic communities and the silent majority, which does not mind allowing space for cultural diversity. 


\section{WHAT ARE THE CONSEQUENCES OF THE FINDINGS OF THE TWO FORMER QUESTIONS FOR THE DISCOURSES ON INTEGRATION?}

As mentioned in the introduction chapter, this dissertation is based on the assumption that every actor should be able to contribute to public discourse and participate in the political process. Here, we suggest how actors from the different societal spheres can fulfil the function in defining the space given to cultural diversity and identity.

Actors from the sphere of government can contribute to the discourse about assimilation and multiculturalism by drafting, enacting, executing and enforcing laws and policies that influence the space given to cultural identities and diversity. In order to do that, moral considerations have to be weighed carefully. Responsibility needs to be taken for reconciling majority and minority interests by facilitating a participatory process on a levelled playing field, where all actors get the chance to express their position. Creating a common understanding and finding a compromise may be a more sustainable aim for the political process about sensitive issues such as the expression of cultural identity, rather than the enactment of laws that inhibit the freedom of citizens.

Business actors can contribute to the discourse by facilitating or withdrawing from the provision of products needed for the expression of cultural identity and diversity. Economic interest might hold them back from providing cultural commodities, but certification may help them to make the facilitation profitable, due to the added value of transparency and benefits of marketing. Thus, the halal certification bodies may want to increase their transparency, offer a participatory process for stakeholders and reduce bureaucracy and double structures. Either they should clear differentiate themselves from each other by means of different standards or they should unify to safe costs for producers and consumers. Careful weighing is advised between the economic interests of the certification bodies and the companies they serve and the needs of the Islamic community. The complete commodification of cultural and religious products may fail to fulfil the needs of minorities.

By producing and selectively publishing new items, media contributes to the discourses of assimilation and multiculturalism. Thus, responsibility should be taken for the discourse that is being promoted and the consequences thereof for integration and tolerance. Producers and publishers of news items should be aware that the adaptation of e.g. populist language, even in criticisms, reproduces the respective discourse. Thus, media should consciously handle their power to influence the discourse.

In the past, ethnic/Islamic communities could influence the public discourse about integration through structural consultation with the government. The only institution that is officially still connected to the government is the Contactorgaan Moslims en Overheid. Furthermore, ethnic/Islamic organizations still lack a professional structure and a network to engage effectively in public discourse. Professionalization, more engagement with the Dutch public sphere and a common position regarding integration may 
strengthen the position of ethnic/Islamic organizations. It is easier for well-organized interest groups to gain access to the political process on equal foot with other societal actors. Moreover, a professional appearance may reduce prejudices and misunderstanding in society and public discourse. In order to achieve that an honest and open debate within and between ethnic/Islamic organizations about their frames for post-integration may be advisable.

\section{RESEARCH REFLECTION}

In this dissertation, a social constructivist lens has been chosen to analyze the governance of cultural diversity. A social-constructivist approach assumes that reality is contingent to our perception and therefore every person experiences reality differently (Moses \& Knutsen, 2012). Within that approach, frame analyses, thematic content analyses and a media analysis are presented. In the introduction, the connection between frame analysis and discourses has shortly been explicated. Limited literature could be found that clearly delineates the relationship between discourse and frame analysis. A methodological elaboration could contribute to the understanding of the influence frames used by different societal actors can have on public discourse.

Within the methodological framework chosen in this dissertation, there are a variety of options to broaden the scope and strengthen the conclusions in future research. First, a comparison could be drawn with other case studies in the field of integration, such as case studies regarding the same topics in other European countries. The question is, for example, whether halal certifiers in other Western countries struggle with the same tension between the needs of the local Muslim community and translational economic interests and how they deal with the situation. It would also be useful to compare the case studies of this dissertation with case studies from countries that apply a completely different discourse of integration and other policies. For example, new insights might be obtained by comparing the decision-making process regarding non-stunned ritual slaughter in the Netherlands with a similar case study in Canada which openly commits to the multicultural discourse.

Second, comparison can concern case studies in the Netherlands regarding different issues related to integration and the space granted for cultural diversity. For example, future research could compare the changing meaning of tolerance to the changing meaning of terms like solidarity or identity. This could strengthen the findings that populism has influenced the public discourse of integration. A comparison between the Dutch parliamentary debate about non-stunned ritual slaughter and the debate about the burka ban could strengthen or complete our understanding how politician position themselves with regards to the space given to cultural diversity. On a broader level, it may be useful to analyze in how far the general public discourse about integration is compatible with the internal discourse about integration among Dutch Muslims. Especially, when assimilation forms the dominant discourse, shifting responsibility for integration completely to 


\section{CONCLUSION}

the Muslim community, it is necessary to understand how Muslims position themselves concerning integration. Chapter 5 of this dissertation can be considered as a starting point for this research.

The approach chosen in this dissertation to the research of governance of cultural diversity is primarily descriptive; it analyses the state of the world, but does not prescribe how it should be or how the preferred state could be achieved. A valuable supplement to this research would therefore be political-philosophical in nature: would assimilation or multiculturalism create a more just and fair society and under which conditions? An ideology-critical analysis could give insights in the strengths and weaknesses of both discourses and challenge power differences. An emancipatory study could give a voice to currently underrepresented or disregarded actors, such as the Muslim community, and thereby influence the public discourse. More concretely, prescriptive research can offer policy options for integration. For that, the complex social reality, empirically studied in this dissertation, needs to be combined with philosophical considerations about how society ought to be in order to assess how reality can be brought to the desired state. Policy options may be based on the assimilation discourse or on multiculturalism.

\section{REFERENCES}

AGER, A., \& STRANG, A. 2008. Understanding integration: A conceptual framework. Journal of refugee studies, 21(2), 166-191.

BLOEMRAAD, I. 2007. Unity in diversity? Du Bois Review: Social Science and Research on Race, 4(02), 317-336.

BLOEMRAAD, I., KORTEWEG, A., \& YURDAKUL, G. 2008. Citizenship and immigration: Multiculturalism, assimilation, and challenges to the nation-state. Annu. Rev. Sociol, 34, 153-179.

MITCHELL, K. 2004. Geographies of identity: multiculturalism unplugged. Progress in human geography, 28(5), 641-651.

MOSES, J., \& KNUTSEN, T. 2012. Ways of knowing: competing methodologies in social and political research: Palgrave Macmillan.

RAWL, J. 1971. A theory of justice. Cambridge, Mass., Belknap Press of Harvard University Press.

RODRÍGUEZ-GARCÍA, D. 2010. Beyond Assimilation and Multiculturalism: A Critical Review of the Debate on Managing Diversity. Journal of International Migration and Integration, 11(3), 251-271. doi:10.1007/s12134-010-0140-x 


\section{Valorization Addendum}

The valorization describes the process of value creation from knowledge by making it accessible for societal or economic activities (National Valorisation Committee, 2011) ${ }^{1}$. The aim of this section is a reflection on the societal and scientific relevance of the tasks executed for, and the results of this dissertation. For that, the following issues shall be discussed: The societal relevance of this dissertation and each separate research chapter; the target groups; and concrete activities and products resulting from the research.

\section{SOCIETAL RELEVANCE}

This dissertation deals with the questions how different societal actors position themselves regarding cultural integration, which opportunities and barriers they encounter and how these findings influence the discourse on integration. Inquiring on the different positions taken is especially relevant since assimilation discourse, which recently gains prominence, assigns responsibility for adaptation solely on culturally different minorities. In this respect, it is crucial to understand how these minorities picture their integration process.

On another note, one of the premises of a liberal democracy is that people should have the freedom to contribute to public discourse and participate in the political process. For that reason, this dissertation assumes that the incorporation of different perspectives on a level playing field is an important source of legitimacy for a liberal democracy. Identifying opportunities and barriers for the positioning of actors in the different societal spheres can help us to discover power imbalances between actors and alert us to lack of representation. Furthermore, it may allow us to realize the potential for the full inclusion of actors from all societal spheres in the deliberation about integration.

Finally, the public discourse of integration influences how people think about the space given to cultural diversity and the expression of cultural identity. The findings of this dissertation help us to understand how the discourse will develop in the future and which role the different actors can play in the unfolding discourse and related policies. In the following, the societal relevance of the separate researches shall be illustrated.

\section{Chapter II: Politics of ritual slaughter}

The research in Chapter II brings up two central questions that need to be addressed in liberal democratic societies today. The first one is in how far minorities have the right to

\footnotetext{
${ }^{1}$ LANDELIJKE COMMISSIE VALORISATIE 2011. Waardevol: Indicatoren voor valorisatie. Utrecht: STW; Technopolis; Rathenau.
} 


\section{VALORIZATION ADDENDUM}

execute their practices and to what extent the majority needs to respect those rights. In the debate, the question was posed in terms of "how much unnecessary suffering of animals is justifiable in order to assure the right to ritual slaughter?" Secondly, the question is posed whether religion should play a role in the public sphere and in how far religious practices should be regulated by secular states. The Chapter illustrates how much politicians struggle to take a position with regards to these complex and normative questions. Furthermore, it creates transparency concerning the motivations and interests that are taken into account while taking a stance. Transparency about the complexity of decision making in the arena of power involving the political game, legal requirements, science, history and economic interests, may create more understanding in society for the position of politicians. Furthermore, making implicit motivations explicit can also help politicians to take more balanced stances regarding normative and sensitive issues.

\section{Chapter III: Private governance of halal food}

Chapter II has the objective to understand the extent to which halal CBs fulfil the needs of the Dutch Muslim community and the influence of international halal governance. Thereby, it gives insights in the governance challenges arising from a globalized food market combined with the heterogenization of values in multicultural societies. The results of the research show that halal certification in the Netherlands is weakly institutionalized and barely responsive to the needs of the Dutch Muslim population. This Chapter entails concrete suggestions to improve the halal certification network based on the ISEAL standards. Examples are increased transparency and accessibility of standards and procedures, efficiency through orchestration, accountability and stakeholder participation. Thus, the results of this research may be translated into an improved certification system or other forms of regulations for halal trade, e.g. meta-governance or governmental policy.

\section{Chapter IV: Influence of Populism on Tolerance}

The objective of this Chapter is to analyze the influence of anti-Islam populism on the meaning of tolerance in Dutch public (newspaper) debate. Several conclusions of this Chapter may be relevant for the peaceful coexistence of culturally diverse groups in the Netherlands: First of all, the tolerance discourse has led to a broader range of subjects of (in)tolerance that can be held responsible by governance actors for a peaceful coexistence. Cooperation between these groups could be stimulated in order to create more tolerance. Likewise, framing a broad range of possible objects of tolerance may show that each actor in society relies on tolerance by others which may create more mutual tolerance. Yet, we need to be careful that the objects of tolerance are not used for further polarization and segregation in society. Uncovering artificial contradictions between different values that society seemingly needs to settle on can help to return to the original idea of individual emancipation and religious tolerance forming two sides of the same coin. In order to maintain societal peace, in cases where actual conflicts between values exist mutual understanding should be created between those affected and a tolerant 
middle ground should be found. Making one's own hierarchy of values explicit may help to create mutual understanding. With regard to the power to interfere, we see that while mainstream opinion leaders receive a greater platform for ventilating their ideas, populists manage to influence the debate by introducing their terminology and setting their agenda. This chapter may create consciousness among mainstream opinion leader about their role in reproducing the populist discourse. Finally, this chapter may stimulate the debate about the limits of tolerance as it has proven that no tolerance for intolerance is no clear delineation. While in the legal system the limits of tolerance are defined by law, societal limits of tolerance may be defined in day-to-day interactions.

\section{Chapter V: Ethnic/Islamic Organizations between Multiculturalism and Assimilation}

As mentioned above, the strengthening assimilation discourse places responsibility for integration solely on the ethnic/Islamic minorities in the Netherlands. Therefore, it is crucial to understand how these groups envision the integration process. The results of this research show that ethnic/Islamic organizations start engaging in the discourse about their integration and that their frames reflect the different approaches that have been taken by the government regarding integration since the 1980s. Even though the idea of assimilation is rejected, agreement exists that socio-economic, political and institutional integration are necessary. Even concerning cultural and emotional integrations, subframes exist that advocate partial adaptation, e.g. the development of an interpretation of Islam that may be combined with Dutch culture. However, there is a contradicting subframe that defends the preservation of the connection between foreign ethnic traditions and Islam and thereby hamper the development of a Dutch Islam. Most ethnic/Islamic organizations reject the one-sided responsibility for assimilation and request a space for their cultural identity. This research is societally relevant, because it shows that the ethnic/Islamic community is diverse and has differing ideas about its 'post-integration' process. Placing responsibility for one-sided assimilation on these minorities may not be a feasible option that will be embraced by these communities. Concretely, this research may help the ethnic/Islamic communities to create an internal debate about how to respond to the external pressure of assimilation. Furthermore, it may create understanding in society for the position of these communities.

\section{TARGET GROUPS}

The target groups result from the three societal spheres that have been analyzed for this dissertation. Firstly, it focuses on politicians and policymakers, who take decisions regarding new legislation answering questions regarding the spaces allowed for the expression of cultural identity in the public sphere. Besides, politicians may strongly influence the public discourse. Secondly, this dissertation appeals to business actors, such as halal cer- 


\section{VALORIZATION ADDENDUM}

tifiers or producers, who may have the aim to facilitated the presence of religiously appropriate food for the Dutch Muslim community. Thirdly, this research targets all members of Dutch society who feel responsible to contribute to a peaceful coexistence of different cultural, religious, ideological groups of all genders and sexual orientations, especially those who participate in the public debate about tolerance. Fourthly, this dissertation focuses on the ethnic/Islamic organizations and communities, who are directly or indirectly affected by the integration discourse.

\section{ACTIVITIES/PRODUCTS}

\section{Participatory process}

Participation is an important aspect of a democratic society. Participation of societal actors in research and policy making increases legitimacy of the decision-making processes and provides creative potential by allowing space for different perspectives. This dissertation is based on the involvement of various societal actors, who shared their perspectives on issues related to integration. It has an emancipatory function by also granting a platform to those actors in society that are often blamed for non-integration, but that are hardly involved on research regarding integration.

\section{Societally relevant publications}

The research done for this dissertation has resulted in three peer-reviewed journal publications and one submitted paper. In this way, these articles may contribute to the social scientific debate about integration, especially emphasizing the need to take into account different societal spheres and actors. Furthermore, each of the articles includes specific research and/or policy recommendations for the different actors involved.

\section{Media coverage}

Part of the research executed for Chapter 3 about Halal governance has been followed by a camera team. The video recordings and an extensive interview about my experience during the field work has contributed to a documentary on Dutch public TV. This documentary had the aim to inform Muslims, but also society at large about the circumstances under which standardization of halal food takes place. The video can be watched on https://www.npo.nl/hoe-halal-is-halal/28-06-2015/VPWON_1244711.

\section{Workshop on qualitative interviews}

Besides the content-related outcomes, the experience during the field work in combination with a Summer course followed at the European Consortium for Political Research has led to the development of a workshop on qualitative interview techniques. This workshop has been included in the curriculum of the MSc Sustainability Science and Policy at ICIS, Maastricht University. 


\section{Summary}

Due to colonial ties, work migration and the intake of refugees, diversity in religious denominations, beliefs, ideologies and practices has increased in the Netherlands during the last centuries. Different approaches have been taken to deal with cultural diversity, ranging from pillarization (1900s-1960s), to multiculturalism (1970s-2000s), and the current demand for assimilation. In public discourse, we experience tensions between those supporting multiculturalism and those who promote assimilation. The former demand the recognition and accommodation of cultural minority identities, while the latter expect minorities to fully adapt to the norms, values and practices of the dominant majority in order to sustain social cohesion. Tensions about the space given to cultural diversity manifest particularly with regards to ethnic/Islamic minorities in public and private debates about ritual slaughter, the construction of mosques, and the headscarf for example. Societal reactions to these tensions are perceived discrimination, prejudices, the rise of antiimmigration and anti-Islamic populism, and radicalization among parts of certain minorities.

Various actors from the native majority and the ethnic/Islamic minorities are involved with the integration discourses of multiculturalism and assimilation. These actors may operate in different societal spheres, such as the government, civil society, or the business sector. In this dissertation, the following questions are discussed:

How do different societal actors position themselves with regards to the space given for cultural identity and diversity?

Which opportunities and barriers do these actors encounter in different societal spheres and how can these be explained?

What are the consequences of the findings of the two former questions for the discourses on integration?

These questions are answered using four case studies from different societal spheres. This makes it possible to execute a holistic and nuanced analysis of a specific situation and to delve into the perspective of different actors involved. Data for this research has been collected between 2014 and 2017 and comprises minutes of parliamentary debates, qualitative interviews, strategy reports, certification standards and news items. All of the data collected are representations of people's ideas, standpoints and reasoning. The analyses executed for these studies include frame analyses, thematic context analyses and a media analysis. 


\section{SUMMARY}

Chapter 1 gives an overview of cultural diversity in the Netherlands and the different approaches to integration taken throughout the $20^{\text {th }}$ and early $21^{\text {st }}$ century. It elaborates on the tensions between multiculturalism and assimilation and introduces the different societal spheres in which discourses and policies of integration are negotiated. The research questions and the methodology are presented as well as the setup of the dissertation.

In Chapter 2, the debate about the prohibition of non-stunned ritual slaughter in the Dutch Parliament in 2011/2012 is analyzed in order to understand how politicians position themselves amidst the tensions described above. The corresponding research question is:

How is cultural diversity expressed in the contestation of value claims regarding nonstunned ritual slaughter and what does this imply for the space given to religious minorities to substantiate their identity?

A frame analysis reveals that tensions exist between minority rights and majority values and with regard to the regulation of religion in the public sphere. The chapter concludes that politicians struggle to position themselves amidst those fundamental questions and certainty is sought in the legal, political, scientific, economic and historical domain. There is no simple answer to the question of what determines the space given to religious minorities to substantiate their identities. Although a political majority decision was taken at the end of a long trajectory, this was a compromise that leaves the controversy with its related uncertainties unsolved.

In Chapter 3, Dutch halal regulation serves as a case study from the economic sphere dealing with the needs of the Dutch Muslim community. Within Islam, different interpretations of halal exist and the pluralistic Muslim community requests diverse halal standards. Therefore, adaptive governance arrangements are needed in the halal food market. Globalization and industrialization have complicated the governance of halal food. A complex network of halal governors has developed from the local to the global level. The aim of Chapter 3 is to analyze how the dynamics of the market-driven governance network influence the representativeness of the regulation for the Dutch Muslim community. The corresponding research question is:

To what extent do the halal governors in the Netherlands address the needs of the Muslim community and what is the influence of international halal governance?

To answer this question, the results of a literature review and eleven qualitative semistructured interviews with the most prominent actors in the Dutch halal governance system are presented. The analysis shows that the halal governance system in the Netherlands is weakly institutionalized and hardly adaptive to the needs of a heterogeneous Muslim community. Improvements are needed concerning stakeholder engagement, transparency, accessibility, impartiality and efficiency.

Chapter 4 examines the influence of the populist movement on Dutch public debate about tolerance and Islam. Historically, religious tolerance has been an integral part of 
Dutch identity. Yet, this image has changed due to the emergence of populism in the last 20 years, which has pre-dominantly focused on the stigmatization of Islam. The corresponding research question is:

How has the emergence of populism changed the meaning of tolerance in the public Islam debate?

A thematic content analysis of articles regarding tolerance and Islam in four large Dutch newspapers from November 2004 until December 2015 has been executed. An analytical framework was applied, breaking down the term tolerance into five components: subject of tolerance, object of tolerance, hierarchy of values, power to interfere and limits to tolerance. The results show that while mainstream opinion leaders receive more attention in the public debate, populists manage to shape the tolerance discourse. A change has occurred regarding who should practice tolerance and what should be tolerated. The populistic discourse emphasizes contradictions between different values, shapes the hierarchy of values and proposes intolerance for Islamic intolerance as the limit of tolerance.

In Chapter 5, different frames of ethnic/Islamic organizations concerning the accommodation of cultural diversity are presented. Assimilation may mean a loss of cultural identity. Therefore, this chapter attempts to understand how ethnic/Islamic organizations respond to the request for assimilation. The corresponding research question is:

How do ethnic/Islamic organizations position themselves regarding the request for assimilation in public discourse?

The research shows that ethnic/Islamic organizations reject the assimilation discourse, but they develop post-integration frames concerning socio-economic, political, institutional, cultural, and emotional issues. Their limited influence on public discourse may be explained by the current power imbalance between the ethnic/Islamic minorities and the Dutch majority, internal incoherence of sub-frames, and a lack of communication.

Chapter 6 discusses the results of the four case studies in the light of the main research questions. An important issue regarding the positioning of societal actors is who should take responsibility. Politicians and business actors find it difficult to take a stance due to the various interests at stake. Ethnic/Islamic organizations are clearer about their positions. The shifting tolerance discourse in the Netherlands offers new opportunities to assign responsibility for peaceful coexistence in an atmosphere of mutual tolerance to all actors in society. A second issue is the commodification of space for cultural diversity, which shows that to some extent the space granted is dependent on the economic interests involved. Thirdly, path dependency - the idea that positions taken today are contingent on decisions taken in the past- plays a role with regards to the space granted to cultural minorities. 


\section{SUMMARY}

Several barriers and opportunities arise when actors try to take and express a position and when common ground is sought. Sensitivity to popular opinion by politicians and sensitivity to economic interests by business actors may be barriers in taking a position. An opportunity may arise through taking a stance on the local level and with regards to concrete situations. In expressing opinions and finding common ground, power differences and the ability to influence public discourse may comprise barriers as well as opportunities. Those with more power can usually influence the tone of public discourse. Yet, we also see that small groups may influence public discourse through a good organizational structure and an effective communication strategy.

The findings allow the definition of possible contributions by each actor involved to the societal discourse on integration. Governmental actors may draft, enact, execute and enforce laws and policies that influence the space given to cultural identities and diversity. By facilitating a participatory process on a levelled playing field, majority and minority interests may be reconciled and compromises might be found. Business actors may facilitate or withdraw from the provision of products needed for the expression of cultural identity and diversity. Certification may help to make the facilitation profitable, due to the added value of transparency and the benefits of marketing. By producing and selectively publishing news items, the media contributes to the discourses of assimilation and multiculturalism. Thus, they should be aware that by adopting the language of populism for example, even in its criticism, they reproduce the respective discourse. Ethnic/Islamic organizations may profit from professionalization, more engagement with the Dutch public sphere and a common position regarding integration to gain access to the political process on equal footing with other societal actors. Moreover, a professional appearance may reduce prejudices and misunderstanding in society and public discourse.

Finally, the Chapter 6 offers a reflection on the research done for this study and suggests future research questions. Future research may focus on methodological elaborations on the relationship between discourse and frame analysis. Content-wise, future studies could extend the research for this dissertation to different case studies or other countries. Finally, philosophical studies may focus on the desired process and possible end state of integration. 


\section{Zusammenfassung}

Aufgrund der kolonialen Vergangenheit, der Arbeitsmigration und der Aufnahme von Flüchtlingen hat sich die die Vielfalt an Konfessionen, Überzeugungen, Ideologien und Praktiken in den Niederlanden in den letzten Jahrhunderten erweitert. Verschiedene Ansätze wurden entwickelt, um mit kultureller Vielfalt umzugehen, von der Pillarisierung (1900er-1960er Jahre) über den Multikulturalismus (1970er-2000er Jahre) bis hin zur aktuellen Forderung nach Assimilation. Im öffentlichen Diskurs erleben wir gegenwärtig Spannungen zwischen den Unterstützern von Multikulturalismus und denen, die für Assimilation werben. Multikulturalisten fordern Anerkennung und Raum für die Ausübung von kulturellen Minderheitenidentitäten, während Assimilationsbefürworter erwarten, dass Minderheiten sich voll und ganz an die Normen, Werte und Praktiken der dominierenden Mehrheit anpassen. Somit soll der soziale Zusammenhalt bewahrt bleiben. Spannungen im Umgang mit kultureller Vielfalt äußern sich insbesondere in Bezug auf ethnische/islamische Minderheiten in öffentlichen und privaten Diskussionen, z.B. über Ehrenmorde, Ritualschlachtung, den Bau von Moscheen und das Tragen eines Kopftuchs. Gesellschaftliche Reaktionen auf diese Spannungen sind unter anderem (empfundene) Diskriminierung und Vorurteile, ein Anstieg von Populismus, der sich gegen den Islam und gegen Einwanderung richtet und die Radikalisierung unter Teilen bestimmter Minderheiten.

Verschiedene gesellschaftliche Akteure beschäftigen sich mit den Integrationsdiskursen des Multikulturalismus und der Assimilation. Sie spielen in verschiedenen gesellschaftlichen Sphären eine Rolle, z.B. in der Regierung, in der Zivilgesellschaft oder in der Wirtschaft. In dieser Dissertation werden folgende Fragen erörtert:

Wie positionieren sich verschiedene gesellschaftliche Akteure in Bezug auf den Raum, der für die Ausübung kultureller Identität und Vielfalt zur Verfügung gestellt wird?

Welche Chancen und Barrieren erfahren diese Akteure in verschiedenen gesellschaftlichen Sphären und wie können diese erklärt werden?

Welche Konsequenzen haben die gewonnenen Erkenntnisse aus den beiden vorherigen Fragen für die Diskurse über Integration?

Diese Fragen werden mit vier Fallstudien aus den verschiedenen gesellschaftlichen Sphären beantwortet. Dadurch ist es möglich, eine ganzheitliche und nuancierte Analyse einer bestimmten Situation durchzuführen und in die Perspektiven der verschiedenen beteiligten Akteure einzutauchen. Die Daten für diese Forschung wurden zwischen 2014 
und 2017 gesammelt. Sie umfassen Protokolle von parlamentarischen Debatten, qualitative Interviews, Strategieberichte, Zertifizierungsstandards und Zeitungsberichte. Alle gesammelten Daten sind Darstellungen von Ideen, Standpunkten und Argumentationen. Die für diese Studien durchgeführten Analysen beinhalten Frame-Analysen, thematische Inhaltsanalysen und eine Medienanalyse.

Kapitel 1 gibt einen Überblick über die kulturelle Vielfalt in den Niederlanden und die verschiedenen Ansätze zur Integration im 20. und frühen 21. Jahrhundert. Es werden die Spannungen zwischen Multikulturalismus und Assimilation und die verschiedenen gesellschaftlichen Sphären, in denen Integrationsdiskurse und Integrationspolitik ausgehandelt werden, beschrieben. Die Forschungsfragen und die Methodik werden ebenso präsentiert wie der Aufbau der Dissertation.

In Kapitel 2 wird die Debatte im niederländischen Parlament aus 2011/2012 um das Verbot der nicht-betäubten Schächtung von Nutztieren analysiert, um zu verstehen, wie sich die Politiker inmitten der oben beschriebenen Spannungen positionieren. Die entsprechende Forschungsfrage lautet:

Wie äußert sich kulturelle Vielfalt in der Auseinandersetzung über Wertvorstellungen in Bezug auf die unbetäubte Schächtung von Tieren und was bedeutet dies für den Raum, den religiöse Minderheiten erhalten um ihrer kulturelle Identität Ausdruck zu verleihen?

Eine Frame-Analyse zeigt, dass Spannungen zwischen Minderheitenrechten und Mehrheitswerten bestehen. Dies wird im Hinblick auf die Regulierung der Religion in der Öffentlichkeit deutlich. Zusammenfassend lässt sich hier feststellen, dass sich Politiker schwer damit tun, in diesen fundamentalen Fragen einen Standpunkt einzunehmen. Sie suchen Gewissheit in Rechtsgrundlagen, der Politik, der Wissenschaft, der Wirtschaft und in der Geschichte. Es gibt keine einfache Antwort auf die Frage, wie viel Raum den religiösen Minderheiten gestattet werden soll, um ihren Identitäten Ausdruck zu verleihen. Obwohl am Ende eines langen Prozesses eine politische Mehrheitsentscheidung getroffen wurde, war dies ein Kompromiss, der die Kontroverse mit den damit verbundenen Ungewissheiten ungelöst lässt.

In Kapitel 3 dient die niederländische Halal-Regulierung als Fallstudie aus der ökonomischen Sphäre, die sich mit den Bedürfnissen der niederländischen muslimischen Gemeinschaft befasst. Innerhalb des Islam bestehen verschiedene Interpretationen von Halal. Die pluralistische muslimische Gemeinschaft fordert vielfältige Halal-Standards. Daher sind im Halal-Lebensmittelmarkt adaptive Governance-Prozesse erforderlich. Globalisierung und Industrialisierung haben die Governance von Halal Lebensmitteln verkompliziert. Ein komplexes Netzwerk von Halal-Gouverneuren hat sich von der lokalen bis zur globalen Ebene entwickelt. Ziel von Kapitel 3 ist es zu analysieren, wie die Dynamik des marktgesteuerten Governance-Netzwerks die Repräsentativität der Regulierung für die niederländische muslimische Gemeinschaft beeinflusst. Die entsprechende Forschungsfrage lautet: 
Inwieweit befassen sich die Halal-Gouverneure in den Niederlanden mit den Bedürfnissen der muslimischen Gemeinschaft und wie ist der Einfluss der internationalen Halal-Governance?

Um diese Frage zu beantworten, werden sowohl die Ergebnisse einer Literaturrecherche als auch die Ergebnisse aus elf qualitativen semi-strukturierten Interviews mit den wichtigsten Akteuren des niederländischen Halal-Governance-Systems genutzt. Die Analyse zeigt, dass das Halal-Governance-System in den Niederlanden schwach institutionalisiert ist und sich kaum an die Bedürfnisse einer heterogenen muslimischen Gemeinschaft orientiert. Verbesserungen sind erforderlich, was den Einfluss von Interessengruppen, die Transparenz, die Zugänglichkeit, die Unparteilichkeit und die Effizienz betrifft.

Kapitel 4 untersucht den Einfluss der populistischen Bewegung auf die niederländische Debatte über Toleranz und den Islam. Historisch gesehen ist religiöse Toleranz ein integraler Bestandteil der niederländischen Identität. Dennoch hat sich dieses Bild durch die Entstehung des Populismus, der sich in den letzten 20 Jahren vorwiegend auf die Stigmatisierung des Islam konzentriert hat, verändert. Die entsprechende Forschungsfrage lautet:

Wie hat die Entstehung des Populismus die Bedeutung der Toleranz in der öffentlichen Islam-Debatte verändert?

Eine thematische Inhaltsanalyse von Artikeln zur Toleranz und dem Islam in vier großen niederländischen Zeitungen von November 2004 bis Dezember 2015 wurde durchgeführt. Es wurde ein analytischer Rahmen angewendet, der den Begriff Toleranz in fünf Komponenten zerlegt: Subjekt der Toleranz, Objekt der Toleranz, Hierarchie der Werte, Einflussmöglichkeiten und Grenzen der Toleranz. Die Ergebnisse zeigen, dass, obwohl Mainstream-Meinungsführer mehr Aufmerksamkeit in der öffentlichen Debatte erhalten, Populisten den Toleranzdiskurs gestalten können. Veränderungen sind aufgetreten bezüglich der Fragen, wer Toleranz üben sollte und was toleriert werden sollte. Der populistische Diskurs betont Widersprüche zwischen verschiedenen Werten, prägt die Hierarchie der Werte und schlägt Intoleranz für Islamische Intoleranz als Toleranzgrenze vor.

In Kapitel 5 werden verschiedene Frames von ethnischen/islamischen Organisationen im Umgang mit kultureller Vielfalt vorgestellt. Assimilation kann einen Verlust der kulturellen Identität bedeuten. Daher versucht dieses Kapitel zu verstehen, wie ethnische/islamische Organisationen auf die Forderung nach Assimilation reagieren. Die entsprechende Forschungsfrage lautet:

Welchen Standpunkt nehmen ethnische/islamische Organisationen in Bezug auf die Forderung nach Assimilation im öffentlichen Diskurs ein?

Die Forschung zeigt, dass ethnische/islamische Organisationen den Assimilationsdiskurs ablehnen, jedoch Post-Integration-Frames in Bezug auf sozioökonomische, politische, institutionelle, kulturelle und emotionale Fragen entwickeln. Ihr eingeschränkter 
Einfluss auf den öffentlichen Diskurs kann durch das aktuelle Macht-Ungleichgewicht zwischen den ethnischen/islamischen Minderheiten und der niederländischen Mehrheit, die internen Inkohärenz von Sub-Frames und den Mangel an Kommunikation erklärt werden.

Kapitel 6 erörtert die Ergebnisse der vier Fallstudien im Hinblick auf die Hauptforschungsfragen. Ein wichtiges Thema bei der Positionierung von gesellschaftlichen Akteuren ist, wer Verantwortung übernehmen soll. Politiker und Wirtschaftsakteure finden es aufgrund der verschiedenen Interessen schwierig hier Position zu beziehen. Ethnische/islamische Organisationen sind klarer in ihren Positionen. Der veränderte Toleranzdiskurs in den Niederlanden bietet neue Möglichkeiten die Verantwortung für die friedliche Koexistenz in einer Atmosphäre der gegenseitigen Toleranz allen Akteuren in der Gesellschaft gemeinsam zuzuordnen. Ein zweites Thema ist die Kommodifizierung des Raumes für kulturelle Vielfalt, die darauf hinweist, dass der Umfang, in dem kulturelle Identitäten ausgedrückt werden dürfen, teilweise abhängig ist von wirtschaftlichen Interessen. Drittens spielt die Pfadabhängigkeit, die Idee, dass heutige Auffassungen von den in der Vergangenheit getroffenen Entscheidungen abhängen, eine Rolle in Bezug auf den Raum, der Minderheiten gewährt wird ihre kulturelle Identität auszuleben.

Der Versuch von Akteuren, einen Standpunkt einzunehmen, auszudrücken und Gemeinsamkeiten zu finden, ruft verschiedene Widerstände hervor, lässt aber auch Chancen entstehen. Hindernisse beim Einnehmen eines Standpunktes können Empfindlichkeiten gegenüber der öffentlichen Meinung von Politikern sein und wirtschaftlichen Interessen von Geschäftsakteuren. Eine Chance kann dadurch entstehen, dass Haltung auf lokaler Ebene und in Bezug auf konkrete Situationen eingenommen wird. Bei der Meinungsäußerung und der Suche nach Gemeinsamkeiten können Machtunterschiede und die Fähigkeit, den öffentlichen Diskurs zu beeinflussen, Hindernisse und Chancen bieten. Diejenigen mit mehr Macht können in der Regel den Ton des öffentlichen Diskurses beherrschen. Dennoch sehen wir auch, dass kleine Gruppen den öffentlichen Diskurs durch eine gute Organisation und mit einer effektiven Kommunikationsstrategie beeinflussen können.

Diese Erkenntnisse ermöglichen es zu analysieren, was die beteiligten Akteure zum gesellschaftlichen Integrationsdiskurs beitragen können. Regierungsakteure können Gesetze und Richtlinien entwerfen, verordnen, durchführen und durchsetzen, die den Raum für kulturelle Identitäten und Vielfalt beeinflussen. Durch eine Erleichterung der Teilnahme am politischen Prozess auf der Basis eines ausgeglichenen Machtverhältnisses, können Mehrheits- und Minderheitsinteressen in Einklang gebracht und Kompromisse gefunden werden. Geschäftsakteure können die Produkte bereitstellen, die für den Ausdruck kultureller Identität und Vielfalt benötigt werden. Zertifizierungen können dazu beitragen, das Angebot dieser Produkte profitabel zu machen, weil sie durch Transparenz und Marketing einen Mehrwert schaffen können. Durch die Produktion und die selektive Veröffentlichung von Nachrichten, tragen die Medien zu den Diskursen der Assimilation und des Multikulturalismus bei. Dies erfordert ein Bewusstsein, dass die Anwendung z. B. von populistischer Sprache, auch in kritischer Form, den jeweiligen Diskurs reproduziert. 
Ethnische/islamische Organisationen können von einer Professionalisierung, der Auseinandersetzung mit der niederländischen Öffentlichkeit und einem gemeinsamen Standpunkt in Bezug auf die Integration profitieren und dadurch den Zugang zu dem politischen Prozess gleichberechtigt mit anderen gesellschaftlichen Akteuren erhalten. Darüber hinaus kann ein professionelles Erscheinungsbild Vorurteile und Missverständnisse in der Gesellschaft und im öffentlichen Diskurs reduzieren.

Abschließend bietet das Kapitel 6 eine kritische Reflexion dieser Studie und schlägt weiterführende Forschungsfragen vor. Methodisch sollten die Beziehungen zwischen Diskurs und Frame-Analyse weiter vertieft werden. Inhaltlich könnte die Forschung auf verschiedene Fallstudien oder andere Länder ausgeweitet werden. Philosophische Studien könnten den gesellschaftlichen Prozess begleiten und eine Vision des möglichen Endzustands der Integration skizzieren helfen. 


\section{Acknowledgements}

Hereby, I would like to express my gratitude and appreciation to everybody who supported my PhD research and writing process.

Special thanks and acknowledgement I would like to express to my supervisor, Pieter Glasbergen, who encouraged me to pursue a PhD when I was still a student, endured my categorical exclusion of this career path, and still supported me when I returned to execute my PhD research anyways. Thanks Pieter, for all your constructive feedback that let my papers rise like phoenixes from the ashes. Your patience and your persistent opposition helped me to question my presumptions, formulate my research questions and findings clearly, and keep focused on the main topic of my research. I can imagine that I have not always made your life easy and I guess you have earned your quiet pension times.

I would also like to express my gratitude to my second supervisor, Marc Davidson, who showed interest in my research immediately when he started working at ICIS. Marc, thank you very much for all your encouraging words, for spontaneous and open brainstorming meetings, and for restructuring the introductions of my papers to make them more concrete and understandable. Keep your (self-) critical and open attitude and your sincere interest in your students and their research.

Thanks to the ICIS management team for showing trust in my ability to complete a PhD by hiring me in 2013. Ron Cörvers, Anja van Bogaert and Pim Martens, without your trust, finance and organizational support this dissertation would not have been possible.

Moreover, I would like to thank my colleague and long-term office mate, Bram Oosterbroek, for assistance with computer-related challenges, for ice creams in summers and tea in winter and for an open ear in times of need. Thanks also to my colleagues Ceren Pekdemir, Julia Backhaus and Christian Scholl for listening to my doubts and ideas, and for reading/commenting my draft papers. Thanks to Alex Baker Shelley and Robert Zaman for proofreading my English spelling and grammar and for after-work beers. Thanks to Annet, Saskia, Maud, Veronique, Astrid and Annemarie for organizational, teaching and emotional support. Thanks to all ICIS staff for your support and feedback during discussions in the kitchen and lunch lectures. Thanks to my fellow PhDs for nice international dinners and general support.

With regards to my data collection, I would like to thank all those who have participated in my studies by giving me insights in their reasons and motivations. Thanks to the politicians of the VVD, PvdA, D66, CDA, Christen Unie, SGP, PvdD, and the PVV, the Rabbi and the representative of the $C M O$, who have contributed to my paper about ritual slaughter. Thanks to the Halal certification bodies, HFFIA, HQC, Halal Correct, HIC, HAC and the Turkish GIMDES; the regional and global governance bodies, SMIIC and NEN; and Bilal Chicken and Mariam Aaras from Voorlichtingsbureau Halalvoeding, for their contri- 


\section{ACKNOWLEDGEMENTS}

bution to the paper about halal certification. Special thanks to Ebubekir Öztüre for arranging a research meeting in Istanbul, for taking me to the Halal Expo Europe in Eindhoven and for allowing me to use his network. Thanks to the ethnic/Islamic organizations, who gave me insights in their perspective on post-integration. To be mentioned: TICF, SICN, NIF, HAK-Der, Platform INS, RMMN, UMMON, WIM, LPNM, Stichting Bekeerling, CMO, IOT and SMN.

I would also like to express my gratitude to all unknown reviewers of my papers and people who have given feedback on my work during conferences, summer/winter schools and courses.

Finally, I would like to thank my private support system of family and friends who carried me through the ups and downs of the PhD trajectory. Mama und Papa, danke dass ihr mich zu einer selbstständigen, kritischen, sozialen und politisch-denkenden Persönlichkeit erzogen habt. Danke, dass ihr mich in meinen Studienentscheidungen bestärkt habt und auch während der Promotionsarbeit immer an meiner Seite wart. Tobias, danke dass du mir die Welt immer wieder aus einem anderen Blickwinkel zeigst und für die vielen guten Gesprächen und Diskussionen. Liebe Familie, danke für eure Unterstützung und dass ich auf euch bauen kann. Jenny, vielen Dank für das tolle Design meiner Doktorarbeit.

Teşekkürler to my partner, Murat Özmen, for refreshing and enlightening discussions about Islam, emotional support in stressful moments, and all the good times. Thanks to Sandra, Joana and their families for regular girls' lunches, inspiring discussions on Brazilian and international politics, and emotional support before and after supervision meetings.

Thanks to my other dear friends in and around Maastricht, Angeli \& Maciek, Alex, Jaida \& Kossaey, Marla \& Zoe, Gyulten, Deniz, Doreen \& Serkan, Antonia, Martin, Nermina and Verena for all our social activities in the last four years. Thanks to my dear friends Yvonne, Milou, Sanne, Geertje, Antoinette, Kim, Galia \& Amitai, Robert, Mandy, Silke, Tassilo, Eline, Debi, and Diane for your visits and phone consultations. Without all of you, I would not be the person I am today. 


\section{About the Author}

Laura Kurth was born on May 27, 1987 in Cologne, Germany. She obtained a BSc International Development Studies from Wageningen University (2011) and a MSc Sustainability Science from ICIS, Maastricht University (2012). From March 2013 until November 2017, Laura was enrolled as a PhD researcher at the International Centre for Integrated assessment and Sustainable development. Under

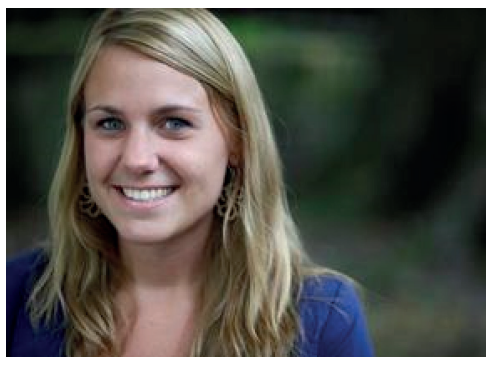
the supervision of Pieter Glasbergen and Marc Davidson, she executed the research for this dissertation. She executed semi-structured in-depth interviews with politicians, religious leaders, business men, halal certifiers and representatives of ethnic/Islamic organizations and executed literature studies. As part of her PhD, she obtained certificates of the courses 'Qualitative Research Methods' and 'Expert Interviews for Qualitative Data Generation' from the European Consortium for Political Research and she presented at Sixteenth International Conference on Diversity in Organizations, Communities \& Nations in Granada.

Besides, Laura was involved in education at BSc and MSc level. She regularly taught the courses 'Introduction to Sustainable Development' and 'Globalization, Environmental Change, and Society' at the University College Maastricht. In the Master program at ICIS, she taught 'Fundamentals of Sustainable Development', 'Governance for Sustainable Development', and supervised Master theses. Furthermore, she introduced the students to the problem-based learning system and organized a workshop on 'Qualitative Expert Interviews'. In the honours program, Laura coached excellent Master students and helped them to develop their competencies.

In her free time, Laura supports Jacana Business Empowerment, a NGO that offers business trainings to small entrepreneurs in Zambia. In addition, she has obtained coaching certificates from the VHS in Aachen, sews her own cloths and started race biking in the beautiful surroundings of Maastricht. After graduation, Laura will move to The Hague to discover the dunes and the sea and work as a lecturer of public administration and governance at Wageningen University. 